


\title{
UNITED STATES ARMY UNILATERAL AND COALITION OPERATIONS IN THE 1965 DOMINICAN REPUBLIC INTERVENTION
}

\author{
by
}

Major Lawrence M. Greenberg

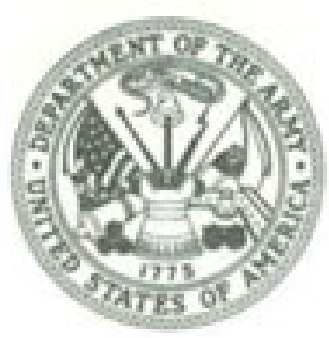

Analysis Branch

U.S. Army Center of Military History

Washington, D.C. 


\section{Library of Congress Cataloging in Publication Data}

Greenberg, Lawrence M., 1949-

United States Army unilateral and coalition operations

in the 1965 Dominican Republic intervention.

Bibliography: p.

Includes index.

Supt. of Docs. no.: D 114.19.2:0p2

1. United States--Military relations--Dominican

Republic. 2. Doninican Republic--Military relations--

United States. 3. United States. Army. Airborne

Division, 82nd--History. 4. Dominican Republic--History-Revolution, 1965. I. Title.

E183.8.D6G74 1987 972.93'054 86-600416

CMH Pub 93.5 
This paper, the fifth publication in the Historical Analysis Series, addresses the role of the United States Army in the Dominican Republic intervention of 1965. Conducted by the 82d Airborne Division, the operation encompassed unilateral combat and peace-keeping duties as well as participation in a regional, multinational peace-keeping military force. The only coalition military force ever fielded by the Organization of American States, the Inter-American Peace Force signified a peak in regional cooperation in the Americas.

For operation planners, Army leaders, and students of military or diplomatic history, this study provides an opportunity to examine the role of large-scale military intervention as an integral part of American foreign policy execution. President Lyndon B. Johnson used American military force to support the diplomatic settlement of the Dominican Civil War and the violence and threat of Communist expansion it possessed. As commander of American ground forces, Lt. Gen. Bruce Paimer, Jr., implemented procedures which stressed often changing definitions of American neutrality, restraint by the individual soldier, and cooperation and coordination with the U.S. Department of State, the Organization of American States, and the six-nation Latin American contingent to the Inter-American Peace Force. General Palmer's ability to deal with political organizations and his determination to support American diplomatic initiatives with the application of firm, but restrained, military force is a model for future coalition operations.

A pertinent section of this paper examines the perceptions, apprehensions, and debates within the Organization of American States that surrounded the formation of the Inter-American Peace Force. The organization's members faced a major dilemma -- did the violence and possible threat of Communist expansion in the Caribbean justify their perceived threat of an American return to unilateral military interventionism? The manner in which they dealt with this problem not only formed the basis for establishing the Inter-American Peace Force but greatly influenced both President Johnson's decision to intervene and the subsequent conduct of the entire operation. 
The author, Maj. Lawrence M. Greenberg, is an Ordnance officer who holds a baccalaureate degree in political science from The Citadel and an advanced degree in international relations. He is a graduate of the Armor Officer Basic Course, the Ordnance Officer Advance Course, the Air Command and Staff College, and the Foreign Area Officer Course. Before corning to the Center of Military History in March 1985, Major Greenberg served in a variety of command and staff positions in the 3d Infantry Division, the Army Explosive Ordnance Disposal Program, and at Field Command Defense Nuclear Agency. His varied military experience and sensitivity to raison d'etat within the international arena have brought new light, understanding, and contemporary relevance to the Army's role in the Dominican intervention and the InterAmerican Peace Force.

WILLIAM A. STOFFT

Brigadier General, U.S. Army

Chief of Military History

November 1986 
At 0200 on Friday, 30 April 1965, a rebel gunman atop an apartment building in Santo Domingo turned his head skyward toward the increasing drone coming from a flight of unseen aircraft. As his eyes adjusted to the night skies, he saw an undulating procession of flashing red lights descending from above the Caribbean toward an unknown destination to his east. Aboard these aircraft were Maj. Gen. Robert H. York and paratroopers of the 3d Brigade, 82d Airborne Division, preparing to land at San Isidro Airfield, some ten miles east of the city. Minutes later the lead aircraft touched down, marking the third armed intervention by American forces into the Dominican Republic during the twentieth century and the first such expedition by the U.S. Army. President Lyndon B. Johnson ordered the division to the island to protect the lives of American citizens living in Santo Domingo, to establish stability amidst the chaos of revolution, and to prevent a Communist takeover of the nation.

The brigade's arrival, on the heels of two successful Marine evacuations of nearly 2,000 people from Santo Domingo on 27 and 28 April, came as a surprise to the international community. Although willing to accept the evacuation of civilians endangered by the growing troubles in the Dorninican Republic, that community saw the introduction of American combat troops as direct intervention into internal matters of a sovereign, however chaotic, nation. As U.S. paratroopers undertook combat and peace-keeping operations, the intervention became the focus of controversy and outrage throughout Latin America and within the U.S. Congress. During the next few weeks, the number of U.S. soldiers in the Dominican Republic increased rapidly as the remainder of the $82 \mathrm{~d}$ Airborne Division arrived in a massive airlift that stretched Air Force transport to its limit. Shortly thereafter, the division began a yearlong mission of peace-keeping and of providing humanitarian aid to the residents of the embattled island. The U.S. Army's ability to produce a military stalemate in Santo Domingo, first alone and later as a member of the Organization of American States' (OAS) Inter-American Peace Force, allowed diplomats to resolve a civil war and return the island to peace. This Army role graphically 
illustrated how military objectives must be subordinated to political goals to achieve success.

Within this paper I have examined the operations which U.S. Forces, Dominican Republic, undertook to carry out its presidential mission as both a unilateral force and a member of a multinational military organization. This study addresses the causes for the intervention and its effects on the Dominican Republic and on U.S. relations with Latin America. To conduct this analysis I have set the complex actions of the key players into a sequence that can be seen in proper perspective. The concerns of the president, Departments of State and Defense, and members of the Organization of American States together influenced the actions of the U.S. force commander, Lt. Gen. Bruce Palmer, Jr.

Distinct phases of the intervention reflected changing concerns of U.S. policy makers as the operation progressed. As these concerns shifted, so did the manner in which U.S. Forces, Dominican Republic, worked toward accomplishing its mission. Several sections of the study deal with causes, actions, or results of the intervention to show how these considerations affected U.S. military operations in the Dominican Republic. Events detailed within these sections cannot, and should not, be looked upon as occurring in isolation but rather as interrelating and simultaneously affecting the entire operation and the way President Johnson and the Joint Chiefs of Staff dealt with it. This interrelationship means that a strict chronology of events would not prove the most illuminating method of examination, so I have concentrated on major events or periods of time in which U.S. actions pursued specific goals. Within these divisions, however, I have addressed the finite elements of the overall operation.

The massive introduction of the $82 \mathrm{~d}$ Airborne Division halted the Dominican revolution in midstream, protected American civilians' lives, and kept the country from falling into the Communist camp. Although President Johnson's goals were achieved, was the overall operation a long-term success, or did the intervention simply postpone an inevitable situation - one that may require the United States to take similar actions in the future, and, if so, should the military response follow the example established in 1965? These questions must be answered to judge the intervention comprehensively. 
Any examination of the 1965 intervention must also address the important area of perception, not only Johnson's perceptions of the dangers that an unstable and possibly leftist Dominican Republic would present to our national security but also the perceptions held by Latin American leaders. This study identifies several differences in perception within the western hemisphere regarding both the possible threat of Communist expansion and the use of American military intervention to prevent it. Indeed, the very principle of intervention appears to have two distinct definitions within the region. To many in the United States, direct intervention is generally to be avoided but is viable when other means have failed to contain communism. To many in Latin America, U.S. interventionism was, and still is, a major threat to sovereignty -a threat equally as dangerous as the possibility of Communist expansion. 1 Having long suffered during periods of U.S. political and economic expansion within the region, the people of Latin America have continued to resist returns of interventionism. This deeply rooted fear was reinforced in 1965 and continues to be significant.

The complexities of the Dominican intervention demand that analysis address more than military operations. There was no doubt that military actions were essential in stabilizing the violent situation that existed in Santo Domingo in 1965, and there is little question that the 82d Airborne Division was successful in subduing the Dominican combatants. The additional, and in this case all-important, consideration which must be analyzed is that of diplomaticmilitary operations. In 1965 our national policy makers used the Army to support and enforce a diplomatic resolution of the conflict.

Today, conditions in the Dominican Republic -- indeed, in the Caribbean basin in general -- are not unlike those of two decades ago. National economies have continued to falter, with many of the region's countries facing real dangers of bankruptcy. Growing populations are placing increased demands on governments for better standards of living, health care, education, and consumer goods. Popular expectations continue to outpace achievements by either local governments or national economies. Resulting frustration and relative deprivation have caused political and social turmoil accompanied by greater Communist influence and activity. 
U.S. economic and security interests have remained strong in both the Dominican Republic and the Caribbean basin. U.S. foreign policy makers have long accepted that the Caribbean's economic development, political stability, and ability to resist Communist incursions are of primary political and strategic importance. The 1983 incursion in Grenada, and the continuing military and econornic commitment to Central America, have shown the emphasis which our political leaders place on this volatile region.

A great number of people have been especially helpful during the production of this study. Discussions with action officers at the Latin American Division of the Defense Intelligence and Analysis Center, PoliticalMilitary Branch of the Office of the Deputy Chief of Staff for Operations and Plans, and Department of the Navy OP613 at the outset helped to focus the study and relate it to current conditions.

My search for information brought me in contact with many who provided the utmost cooperation and, in more than one instance, a great deal of patience. At the Center of Military History, Miss Hannah Zeidlik provided original historical studies and chronologies, while Ms. Carol Anderson and Ms. Mary Sawyer provided extensive library support.

I appreciate the patience and expertise of the archive staft at the Military History Institute, Dr. Richard Sommers and Mr. David Keough, for their assistance in obtaining original personal papers and oral histories. Mr. John Slonaker assisted in my search for secondary studies both at the institute and at the U.S. Army War College, and I owe special thanks to Mr. Randy Raker, keeper of the historical records vault, for his tireless efforts in locating and providing me with copies of vital operational histories and after-action reports.

Perhaps the greatest single contributor to my work was Dr. Lawrence Yates of the Combat Studies Institute, U.S. Army Command and General Staff College. His expertise on the subject, his willingness to share his opinions and collected documentation on the Dominican intervention, and his review of the draft manuscript were essential to completing the study within time and travel constraints. 
Mr. David Rogus and Mr. Neal Petersen, and the Foreign Affairs Information Management Center of the U.S. Department of State, provided access to the personal papers and memoranda of several key diplomatic personalities who brought the Dominican Civil War to an end. At the Organization of American States' Columbus Memorial Library, the assistance of Sra. Myrian Figueras, Research Librarian, was invaluable, since my mastery of the Spanish language leaves many areas for improvement.

I would especially like to thank those who, in addition to Dr. Yates, reviewed the draft of this study and provided their insight and observations: Dr. David F. Trask, Dr. Alexander "Sandy" Cochran, Jr., Lt. Col. Robert Frank, Lt. Col. Richard O. Perry, Maj. Peter Kozumplik, Maj. Bruce Pirnie, and Dr. Edgar Raines (all from the Center of Military History); Dr. Walter Poole (Joint Chiefs of Staff Historical Division); Capt. John Williamson and associates (History Department, United States Military Academy); and Mr. Neal Petersen (Department of State). And, without the fine work of Ms. Joyce Hardyman, my editor, and Ms. Linda Cajka, who produced the cover design and did all of the maps and graphics, this project could not have been completed. To those 1 have failed to mention by name, thank you as well.

Finally, my deepest appreciation goes to my bride, Rebecca. Not so much for coining "You're not an historian till the world says you're an historian," but for always listening and giving me the courage to face just one more rewrite.

For interpretations and errors of fact or omission, I alone retain full responsibility.

\author{
LA WRENCE M. GREENBERG \\ Major, Ordnance Corps \\ Military Analyst
}

Novernber 1986 
Notes - Preface

1. M. Margaret Ball, The OAS in Transition (Durham, N.C.: Duke University Press, 1966), p. 591. 
I. HISTORICAL BACKGROUND ............. 1

From Discovery to Trujillo . . . . . . . . . 1

The Trujillo Era ... . . . . . . . . . . 5

The Pre-Civil War Governments . . . . . . . 7

Notes ................. 11

II. THE CALL FOR HELP ............. 13

The Outbreak of Civil War ............. 13

The Loss of Law and Order . . . . . . . . . . . . 17

The Decision To Intervene . . . . . . . . . . 23

Notes................ . . 27

III. U.S. UNILATERAL ACTIONS . . . . . . . . . . 31

Phase I -- Evacuation . . . . . . . . . . . . . 32

Phase II -- Stability Operations . . . . . . . . . . 36

Phase III -- Unilateral Peace-Keeping . . . . . . . 47

Notes . . . . . . . . . . . . . 56

IV. THE INTER-AMERICAN PEACE FORCE . . . . . . 60

Toward an Inter-American Force . . . . . . . . . 60

Initial OAS Debates .............. 61

Debates on an Inter-American Force. . . . . . . 65

Composition of the Force . . . . . . . . . 69

The Resolution Becomes Reality . . . . . . . . . 70

Operations in Santo Dorningo . . . . . . . . . 74

The Provisional Government and the Peace Force . . . 77

The Election of June $1966 \ldots . . . . . . .43$

Notes................. 86

v. CONCLUSION ................. 92

Political Operations . . . . . . . . . . . . 93

Military Operations . . . . . . . . . . . . 94

Summary . . . . . . . . . . . . . . . . . 96

Notes .................. . . . 97

Appendix

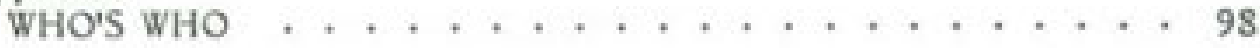

BIBLIOGRAPHY .................. 103

INDEX ........................ 111 


\section{MAPS}

No.

Page

1. Caribbean Region ............. . . . xiv

2. Dominican Republic ................. . 2

3. Santo Domingo (1965) .............. 19

4. Santo Domingo and Haina ............. 35

5. Santo Dorningo -- Initial U.S. Advance . . . . . . . . . 41

6. Santo Domingo and the Initial Line of Communication . . . . 48

7. Santo Domingo -- Stabilized Situation . . . . . . . . 52

8. Santo Domingo -- Expanded Line of Communication . . . . 54

9. Dominican Republic -- Santiago and Barahona ....... 81

\section{CHARTS}

No.

$\underline{\text { Page }}$

1. Command Relationship, U.S. Forces . . . . . . . . . 45

2. Command Relationships, Inter-American Peace Force . . . 68

3. Organization, Inter-American Peace Force . . . . . . . 75

TABLE

No.

Page

1. Inter-American Peace Force Casualties:

April 1965-September 1966 . . . . . . . . 85 


\section{UNITED STATES ARMY UNILATERAL AND COALITION OPERATIONS IN THE 1965 DOMINICAN REPUBLIC INTERVENTION}




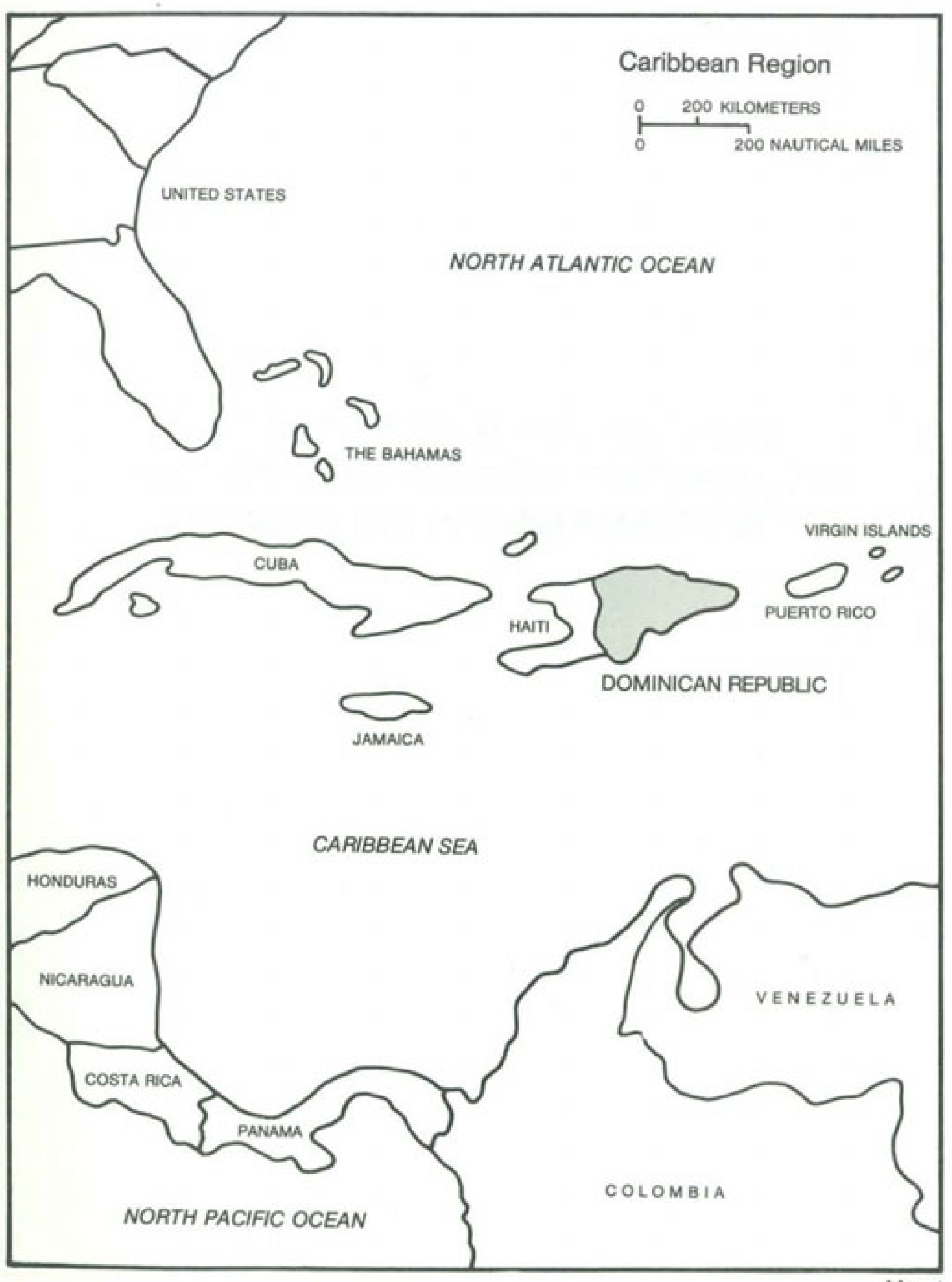




\section{Historical Background}

Once considered the jewel of the Caribbean, the Dominican Republic has a long and violent history. This small nation has been subjected both to rule by colonial powers and, after independence, to a long succession of corrupt military and civilian leaders. Throughout the years it has been the object of numerous American military and economic interventions, and it has remained economically dependent on the United States. (Map 2)

The root cause for the 1965 civil war, which led to President Johnson's decision to commit U.S. combat troops to the island for the third time in the twentieth century, lay in the turbulent history of the Dominican Republic. Dominican perceptions of power and long-established violent means of using it to achieve political change did little to promote either political maturity or democracy in the republic. The thirty-year dictatorial rule of Generalissimo Rafael Leonidas Trujillo Molina epitomized Dominican political immaturity and resulted in the nation being thrown into chaos after his assassination in 1961 . The political vacuum that Trujillo left behind would have direct and long-lasting effects, and it pushed the nation toward civil war in 1965.

\section{From Discovery to Trujillo}

Christopher Columbus discovered the island of Hispaniola on 5 December 1492, during his first voyage to the New World, and claimed it for the Spanish monarchy. Santo Domingo, founded by Columbus' brother, Bartholomew, on 4 August 1496, became the first permanent Spanish settlement and the seat of early Spanish power in the Americas. Originally the Spanish used the island for agriculture -- coffee and sugar, and in 1520 they introduced African slaves to supplement native Arawak Indians whom they had pressed into slavery. ${ }^{1}$ With the discovery of gold and silver in the New World, the Spanish government soon lost interest in Hispaniola and diverted its attentions toward Mexico and Peru. The slaves remained and became the basis for the Dominican population.

During the sixteenth and seventeenth centuries the island was a haven for Caribbean pirates and buccaneers. In 1585 Sir Francis Drake, the English 


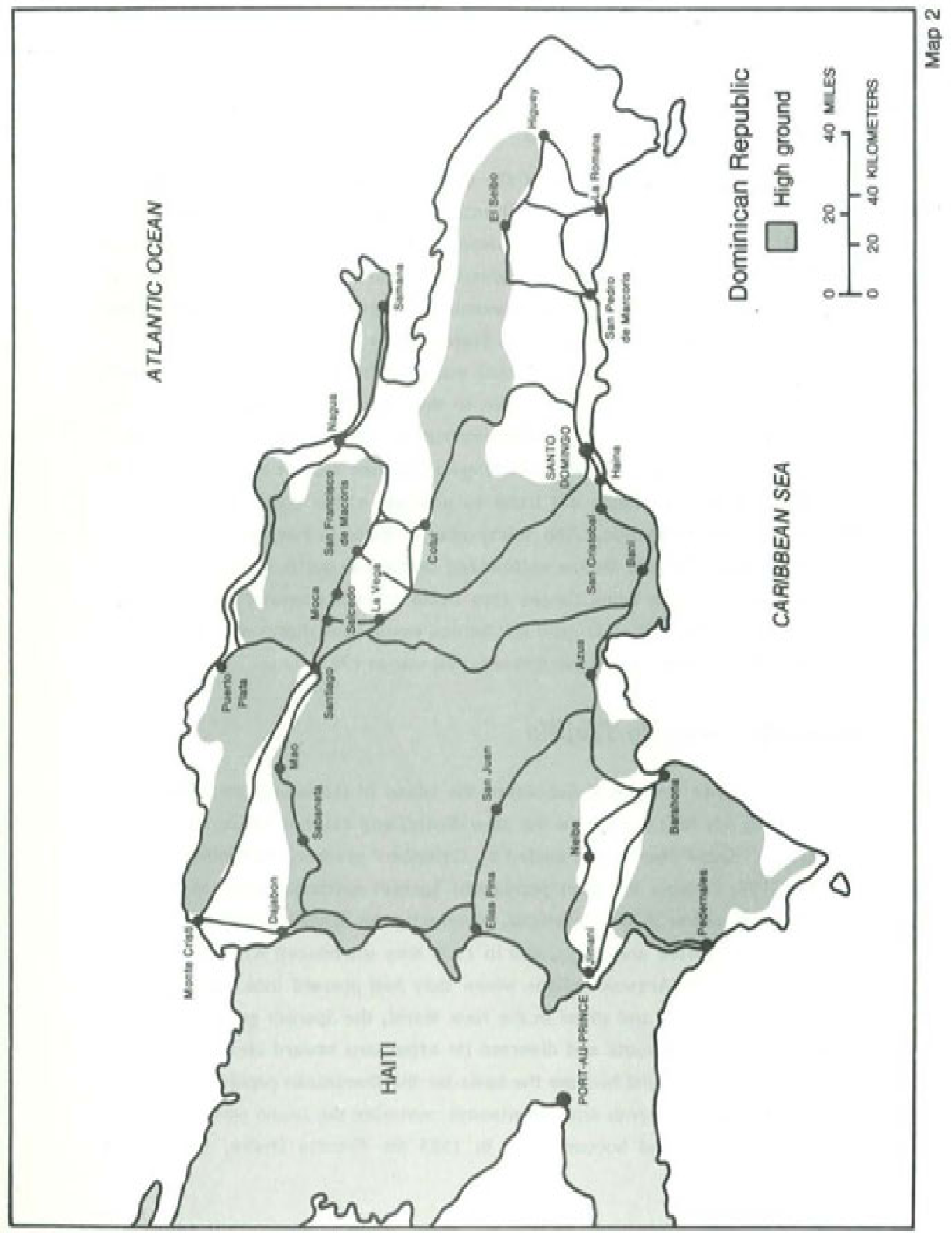


privateer, captured Santo Domingo, the capital of the colony which bore the same name, from the small Spanish garrison and held it for ransom. In the mid1600 s French buccaneers captured the western part of Hispaniola, known as St. Dominique, and renamed it Haiti. Spain did not challenge their actions.

In 1801 local landowners and merchants repelled the first Haitian invasion of the colony of Santo Domingo. These Haitian attacks occurred periodically until 1822 and continued, although with less regularity, well into the twentieth century. Bolstered by success against the Haitians and French reluctance to post large numbers of troops on the island after 1803, Dominicans drove the French from Santo Domingo in 1809. At the request of Dominican planters, Spain resumed control. Having little desire to garrison many troops on such relatively unprofitable soil, Spain once again lost the colony in December 1821, when Jose Nunez de Caceres seized the government, declared Santo Domingo independent, and named the former colony the Dominican Republic. In what may have ended the shortest experience of independence in the New World, Haiti invaded in January 1822 and conquered the new republic in less than thirty days.

The Dominican Republic finally achieved independence in 1844 . Led by Juan Pablo Duarte, Francisco del Rosario, and Ramon Mella, Spanish colonists drove the Haitians out of the country. Together with other prominent families from the 1844 revolution, the Imberts and the del Prados, these leaders began to form a political legacy based on power struggles between contending personalistic power brokers, or caudillos.

The country continued to suffer from this form of power politics where ability and competence were always subordinated to personal appeal and family position. Political development was almost nonexistent. In 1861 and 1869 Dominican presidents attempted literally to sell the country. In 1861, President Buenaventura Baez succeeded in having his country annexed for a price by Spain, but four years later another revolt by plantation owners and merchants overthrew the Spanish government for the final time. ${ }^{2}$ In 1869 , President Ulysses S. Grant ordered U.S. Marines to the island for the first time. Pirates operating from Haiti had been raiding U.S. commercial shipping in the Caribbean, and Grant directed the Marines to stop them at their source. Following the virtual takeover of the island, the Dominican president of fered to 
sell the country to the United States for $\$ 100,000$ in cash and $\$ 50,000$ in armament credits. ${ }^{3}$ Although President Grant supported the arrangement, the Senate, under the leadership of abolitionist Charles Sumner, failed to pass the annexation legislation. ${ }^{4}$

American military intervention occurred again in 1905 when President Theodore Roosevelt, amidst a rising threat of European interventionism in the hemisphere, sent the Marines to Santo Domingo. A civil war on the island had so depleted the national treasury that European nations were threatening to seize the country to get payment on their loans. To prevent this, Roosevelt had the Marines seize the Dominican customs house and administer repayment. Fortyeight percent of the customs duties received went to the Dominican government, with the U.S. Navy Department using the remaining 52 percent to repay foreign debts. 5 Following the seizure, Roosevelt received an offer from the Dominican president, Ulises Heureaux, to annex the republic; unlike Grant, he rejected it. 6

On 5 May 1916, President Woodrow Wilson ordered the Marines back to Santo Dorningo to quell domestic violence and economic chaos. This time they stayed for eight years to manage the country's finances and preserve the peace, and the U.S. Navy Department virtually ran the entire country. American troops left in 1924 after the election of General Horacio Vasquez and as European involvement with the hemisphere withered following World War I, although American control over the custorns house continued until 1941. Much of the resentment Dominicans expressed toward the United States in 1965 was linked directly to this earlier military occupation of the island. ${ }^{7}$

Before the election of Rafael Trujillo in 1930, there had been 123 political heads of state in the Dominican Republic since independence in 1844. Most of them came from the military and displayed less than admirable public consciousness. The country had little experience in democratic government or in nonviolent political development. ${ }^{8}$ John B. Martin, former ambassador to the Dominican Republic and special assistant to the president in 1965, aptly described the island's history when he referred to it as showing ". . no development of social or political institutions. It shows no growth as a nation."9 


\section{The Trujillo Era}

Rafael Trujillo began his ascent to power through the national police in the 1920s. Vacancies above him occurred periodically, through sudden death, retirement, or resignation, and Trujillo was promoted into them. Then, by filling his vacated position with a protege, Trujillo built a power base with which he could influence others to seek retirement or new careers. In 1927 he became the chief of the national police and principal adviser to President Horacio Vasquez. The following year Trujillo formed the Dominican Secret Police, which he headed, and converted the national police into an autonomous paramilitary force under his direct command. In 1930 he marshaled his supporters and his forces and successfully ran for office in a typical Dominican election where power and coercion replaced free choice and accurate ballot counting.

Early in his presidency Trujillo developed considerable mass support within Santo Domingo, thanks in great measure to a natural disaster. Shortly after he took office, a hurricane destroyed most of the city. He rebuilt Santo Domingo, renamed it Ciudad Trujillo (Trujillo City), and began to fill his pockets with diverted funds and construction kickbacks. The pattern of gaining financially from public office was not new in the Dominican Republic. Trujillo simply refined the process and took the tradition to new heights. He was an ardent anti-Communist and an economic nationalist who took great pride in developing Dominican industry and manufacturing as long as he, and his family, received their share of the profits. At the time of his death in 1961, Trujillo and his immediate family had amassed an estimated worth exceeding $\$ 800$ million, owned one-third of all arable land in the country, and controlled twothirds of Dominican sugar production. 10

Rafael Trujillo ruled the Dominican Republic for thirty years as a ruthless dictator and became one of the most graphic examples of a Latin American caudillo ever to hold office. During his long regime the country had no independent legislature, judiciary, or political opposition. He used the secret police extensively to eliminate political opposition and to prevent several coup attempts during and after World War II. The secret police allegedly murdered 
more than 500,000 people during the Trujillo era, including some 37,000 Haitians. Another 1,500 victims were squatters whom Trujillo ordered eliminated after being asked what he was going to do about their setting up a shantytown on the outskirts of Santo Domingo. 11

In June 1960 the Organization of American States' Human Rights Commission issued a scathing report on violations in the Dominican Republic. Supported by the U.S. State Department, the commission accused Trujillo of "flagrant and numerous violations of human rights" against the citizens of the Dominican Republic.12 Trujillo retaliated against the chief proponent of the report, Venezuelan President Romulo Betancourt, by actively supporting an assassination attempt. The plot failed and Trujillo's involvement in the conspiracy became public in a report by the OAS Council's (the organization's general assembly) investigating committee. Composed of representatives from the United States, Argentina, Mexico, Panama, and Uruguay, the committee verified Dominican complicity and placed responsibility on "high officials" within the government. 13

Responding to a Venezuelan call for collective action, on 20 August 1960 the OAS Council passed a resolution invoking diplomatic and economic sanctions against the Trujillo government. The resolution, passed fourteen to one (the Dominican Republic dissented while Brazil, Argentina, Guatemala, Haiti, Paraguay, and Uruguay abstained), marked the first time that the organization had taken such actions against a member nation. ${ }^{14}$ As a show of support, President Dwight D. Eisenhower suspended all economic and diplomatic relations with the Dominican Republic. Trujillo attempted to placate both the Organization of American States and the United States by resigning from office, allowing Vice-President Juaquin Balaguer to assume the presidency and announcing that he would support Balaguer's plans to democratize the country. ${ }^{15}$ None of these actions were sincere. Although Trujillo was no longer the president, he continued to wield power, and the democratic plans he spoke of were empty promises.

Trujillo was assassinated on 31 Nay 1961 by a small band of conspirators led by Antonio de la Maza and Antonio Imbert Barrera. 16 The coup attempt that followed failed to seize power and all of the conspirators except Imbert were found and executed by Ramfis Trujillo, the dictator's son, who remained in 
de facto control of the government for the next six months through his position as commander of the armed forces. Trujillo's brothers, Hector Bienvenido and Jose Arismendi Trujillo, returned to the country and began immediately to plot against President Balaguer. 17 On 18 November 1961, as a planned coup became more evident, U.S. Secretary of State Dean Rusk issued a warning that the United States would not "remain idle" if the Trujillos attempted to "reassert dictatorial domination" over the Dominican Republic. 18 Following this warning, and the arrival of a fourteen-vessel U.S. naval task force within sight of Santo Domingo, Ramfis and his uncles fled the country on 19 November with $\$ 200$ million from the Dominican treasury.

President John F. Kennedy's show of naval force in 1961 continued what had been the preferred method of displaying American might in the Caribbean since World War II; that is, to have forces visible but not sent ashore. This action was consistent with his desire to continue the American policy of avoiding direct intervention if results could be achieved by threat of arms. President Johnson and the Joint Chiefs of Staff contemplated a similar course of action in 1965 but rejected it in light of rapidly moving events in Santo Domingo and administration fears of another Cuban-style Communist takeover of a Caribbean nation.

\section{The Pre-Civil War Governments}

Even in death, Trujillo played an important part in events that swept the Dominican Republic in 1965. His ruthless elimination of political opposition left a vacuum in which neither trained subordinates nor any tradition of democratic principles existed. Political leaders entered office with a greater desire for self-aggrandizement than for public service. The coup had becorne the accepted method for political change, and only the strong leader survived.

With the Trujillo family and most of the Dominican treasury gone, Joaquin Balaguer found himself president of a bankrupt nation facing growing social unrest. The Dominican military was worried about social instability and concerned about its own position without the Trujillos. Talk of liberalization within the government threatened the military's long-standing privileges and social stature. At the opposite end of the political spectrum, followers of Dr. 
Juan Bosch and his newly formed Dominican Revolutionary Party (Partido Revolucionario Dominicano), known as the PRD, pushed for sweeping social reforms in reaction to Trujillo's thirty years of repression. The small middle class, representing political moderates, was unhappy over failing economic conditions and unsure about the intentions of the military. The Dominican social stew was once again coming to a boil.

Balaguer decided that his political survival depended on the lifting of OAS and U.S. economic sanctions imposed during the final days of the Eisenhower administration in 1960. He formed a council of state, with representation from the military and prominent businessmen, so as to distance himself from Trujillo's reign. Although the formation of the council succeeded in having the sanctions lifted (the Organization of American States did so on 4 January 1962 and the United States on 6 January), the new government was unable to deal with domestic pressures. On 17 January 1962, General Pedro Rafael Rodriguez Echevarria, chief of the Dominican armed forces, overthrew Balaguer and his council of state. 19

The following day Col. Elias Wessin y Wessin, since 1961 commander of the 1,500-man autonomous Armed Forces Training Center at San Isidro Airfield, and his troops ousted General Rodriguez in a counter coup. Wessin y Wessin reestablished the council of state under the leadership of Rafael F. Bonnelly, Trujillo's former minister of the interior, with Donald Reid Cabral, an American-educated automobile dealer in Santo Domingo, acting as vicepresident. Balaguer was unavailable to head the new government, having fled to the United States at the outbreak of the first coup. The new council announced elections for December 1962, the first free elections in some thirtyeight years, but did little else. 20

On 20 December Dominicans went to the polls and elected Juan Bosch to the presidency by an overwhelming two-to-one margin. Bosch, who had remained in exile for twenty-four years before the election, was a magnetic speaker and writer whom the American embassy considered a social democrat. 21 Shortly after his inauguration on 27 February 1963 he came under verbal attack from the military and conservative businessmen when he legalized the nation's Communist parties and appointed several political liberals to his cabinet. 22 Bosch also pursued liberalized policies toward personal freedorns, 
land reforms, and increased taxation of business and industry.

In September 1963 Bosch demanded the resignation of Wessin y Wessin. In response, Wessin y Wessin led a successful coup against Bosch and announced, "The Communist doctrine, Marxist-Leninist, Castroite, or whatever it is called, is now outlawed." 23 Wessin y Wessin's troops captured Bosch in the presidential palace on 25 September and put him aboard a plane to Puerto Rico. President Kennedy was outraged at the ouster of an elected government and threatened to sever all U.S. economic aid to the Dominican Republic, as he had already done following coups in Argentina, Panama, Guatemala, Peru, and Honduras during 1962 and 1963. Faced with this prospect, newly promoted Brig. Gen. Wessin y Wessin established a three-man junta headed by Bosch's foreign minister, Donald Reid Cabral. Having formed a new government, Wessin y Wessin stepped quietly back into his role as commander of the training center. 24 The threat of an American economic quarantine was averted.

The triumvirate was inaugurated on the steps of the national palace on 26 September 1964 and immediately promised new general elections for September 1965.25 Reid had a strong pro-U.S. economic and political policy. So closely was he associated with the United States and with local American businessmen that the American community called him Donny and his countrymen El Americano. Despite his American connections, he was unable to cope with the declining economy and the growing split between pro- and anti-Bosch factions in both the civilian population and the military. The younger, more liberal officers tended to favor Bosch's return, which the older officers vehemently opposed. Increasingly, Bosch made taped radio broadcasts from small stations in Santo Domingo and from Radio Havana calling for his return and the reinstatement of the 1963 constitution that was abrogated by the Wessin $y$ Wessin coup. 26

The Reid council was trapped between political extremes. In attempts to improve the nation's economy and reduce corruption, Reid cut back the military budget, closed military exchanges, and stopped the lucrative smuggling enterprises that many senior officers had enjoyed during the Trujillo era. All of these programs threatened the military and produced a great deal of unrest among its senior leaders. At the same time, many junior officers were unsatisfied with the rate at which the older, Trujillo period, senior officers 
were being retired. They felt that Reid was moving too slowly and doubted that the promised free elections would take place. 27

Both factions in the military were planning coups against Reid, and he realized that his position was becoming untenable. 28 The general perception in Santo Domingo, both at the presidential palace and in the American embassy, however, was that any coup attempt would not occur until election campaigning began in the fall of 1965. On 22 April, just two days before the start of the civil war, Reid told U.S. Ambassador W. Tapley "Tap" Bennett, Jr., that he was aware of the problems and knew of the planned coups but that everything would be fine for a few more months. 29 Bennett, a career diplomat who had previously served in Bolivia and Panama but who had been in the Dominican Republic for only five and a half months, was convinced. On the following day he left to visit his ailing mother in the United States. 30

The stage was set for civil war. The afternoon before the start of the rebellion the U.S. naval attache, Marine Lt. Col. Ralph Heywood, shot doves with Dominican General Imbert outside Santo Domingo, and eleven members of the U.S. Military Assistance Advisory Group left for a routine meeting in Panama. Neither Reid nor the U.S. State Department expected violence to erupt the following day. 


\section{Notes - Chapter I}

1. Sumner Welles, Naboth's Vineyard (New York: Payson and Clarke, 1928), p. 7. This two-volume set is an exceptionally well written and detailed account of early Dominican history.

2. Richard J. Barnet, Intervention and Revolution (New York: New American Library, 1968), p. 15i.

3. Ibid., p. 153.

4. Luis Iturralde Chinel, La O.E.A. y la Revolucion Dominicana (Washington, D.C.: Union Panamericana, 1967), p. 4.

5. Herbert G. Schoonmaker, "United States Military Forces in the Dominican Crisis of 1965," doctoral dissertation (A thens: University of Georgia, 1977), p. 4.

6. Piero Gleijeses, The Dominican Crisis: The 1965 Constitutionalist Revolt and American Intervention (Baltimore: Johns Hopkins University Press, 1978), p. 14.

7. John H. Andrews, "The Dominican Intervention 1965-66" (Ft. Leavenworth, Kan.: U.S. Army Command and General Staff College, 1 Mar 82), p. 2.

8. Audrey Bracey, Resolution of the Dominican Crisis, 1965: A Study in Mediation (Washington, D.C.: Institute for the Study of Diplomacy, 1980), p. xi.

9. Richard W. Mansbach, ed., Dominican Crisis 1965 (New York: Facts on File, 1971), p. 7.

10. U.S. Congress, Senate, Committee on Foreign Relations, "Background Information Relating to the Dominican Republic," 89th Cong., Ist sess. (Washington, D.C.: Government Printing Office, Jul 65), p. 7.

11. The man Trujillo ordered to kill the Haitians was Lt. Gen. Fausto Caamano, the father of Col. Francisco Caamano, who later led the Constitutionalist rebels in 1965. Eldredge R. Long, Jr., "The Dominican Crisis 1965: An Experiment in International Peace Keeping," student thesis (Newport, R.I.: U.S. Naval War College, 1967), p. 6.; Iturralde Chinel, Revolucion Dominicana, p. 6.

12. Iturralde Chinel, Revolucion Dominicana, p. 9.

13. Jerome Slater, The OAS and United States Foreign Policy (Columbus: Ohio State University Press, 1967), p. 190. 
14. Iturralde Chinel, Revolucion Dominicana, p. 10; Slater, The OAS and United States Foreign Policy, p. 190.

15. Gleijeses, The Dominican Crisis, p. 28.

16. Barry M. Blechman and Stephen S. Kaplan, Force Without War (Washington, D.C.: Brookings Institute, 1978), p. 291; Slater, The OAS and United States Foreign Policy, p. 214.

17. Blechman and Kaplan, Force Without War, p. 298; Iturralde Chinel,

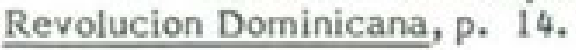

18. U.S. State Dept Bulletin, 4 Dec 61, p. 931.

19. Bracey, Resolution of the Dominican Crisis, p. xii.

20. John Carey, ed., The Dorninican Republic Crisis 1965 (Dobbs Ferry, N.Y.: Oceana Publications, 1967), p. 4; Bracey, Resolution of the Dominican Crisis, p. xii.

21. Iturralde Chinel, Revolucion Dominicana, p. 18.

22. Before legalization in 1963, Dorninican Communist parties existed underground and, although small in number and diverse in orientation, were harassed by the Trujillo, Balaguer, and Bonnelly governments. Long, "Dominican Crisis," p. 14.

23. Jerome Slater, Intervention and Negotiation: The United States and the Dominican Republic (New York: Harper and Row, 1970), p. 17; Blechman and Kaplan, Force Without War, p. 304.

24. "Dominican Coup Deposes Regime," New York Times, 26 Apr 65.

25. Iturralde Chinel, Revolucion Dominicana, p. 23.

26. Center for Strategic Studies, Dominican Action - 1965: Intervention or Cooperation (Washington, D.C.: Georgetown University, Jul 66), p. 4.

27. Schoonmaker, "U.S. Forces in the Dominican Crisis," p. 19.

28. John Bartlow Martin, Overtaken By Events (New York: Doubleday, 1966), p. 645.

29. Center for Strategic Studies, Dominican Action, p. 8.

30. "Envoy On Firing Line," New York Times, 1 May 65; Schoonmaker, "U.S. Forces in the Dorninican Crisis," p. 21. 


\section{The Call for Help}

\section{The Outbreak of Civil War}

With U.S. Ambassador Bennett and all but two of the Military Assistance Advisory Group staff out of the country, Reid moved against the latest threat to overthrow his government on Saturday, 24 April 1965. Acting on information

he received from Chief of the Armed Forces General Riviera Cuesta that a group of junior officers was planning a coup for 26 April, he revoked the commissions of three young lieutenant colonels and sent General Riviera to the 16 th of August Camp to collect their commissions. Instead, the officers seized the general. Sensing support from the population for the return of Bosch and the 1963 constitution, the officers announced over local radio stations that they were in revolt against the Reid government and adopted the label of Constitutionalists. Shortly after the announcement a second army base, the 27 th of February Camp, joined the rebellion and raised the number of Dominican soldiers in revolt to $1,500.1$ One unit of the navy's elite frogmen defected to the rebellion, while the air force remained virtually intact although initially inactive in supporting Reid.

Although the conspirators had not anticipated seizing General Riviera, the event provided the catalyst for their move against Reid. ${ }^{2}$ While the rebel military emptied the armories at the two camps (which contained an estimated 20,000 weapons), leftist political leaders in Santo Domingo mobilized. Miguel Soto and Jose Francisco Pena, both leaders of Bosch's political party, took control of the official state radio station, Radio Santo Domingo, and urged the people to demonstrate in the streets for the return of Bosch and the 1963 constitution. Announcements were broadcast that anyone who wanted guns could get them at the two camps. The rebel military also loaded some weapons aboard trucks and took them to large parks within the city, where they were distributed en masse to men, women, and teenagers alike. ${ }^{3}$

Reid immediately called upon his service chiefs to mobilize their forces and crush the rebellion. At the outbreak, the Dominican armed forces consisted of 17,610 regulars: 10,530 in the army (including the Armed Forces Training 
Center tank corps), 3,370 in the navy, and 3,710 in the air force. ${ }^{4}$ General Wessin $y$ Wessin decided that neither he nor his army troops at the training center would leave San Isidro to keep Reid in office. The chiefs of the navy and air force, Commodore Francisco Rivera Caminero and Brig. Gen. Jesus de los Santos Cespedes, also found it convenient to adopt a wait and see attitude before committing themselves, or their troops, against the rebels. Reid's only offer of help came from General Imbert, who proposed to attack the camps with national police in exchange for being named secretary of the armed forces. Reid declined Imbert's offer. 5

At the U.S. embassy in the heart of Santo Domingo, Charge d'Affaires William B. Connett, Jr., wired the State Department with the first reports of trouble at 1530 on 24 April. 6 Connett reported that although the situation was confused, the government would probably be able to get the support of the armed forces and remain in power. Later that afternoon at Camp David, Under Secretary of State George W. Ball briefed President Johnson on the situation in Santo Domingo. 7 Since the trouble had but recently begun and American lives were not in immediate danger, Johnson asked only to be kept informed and turned his attention back toward Southeast Asia.

What Connett and Reid had not foreseen was the rapid and surprisingly well organized actions of the country's Communist-oriented political parties. Of these, the Soviet-oriented Dominican Revolutionary Party and the Castroite 14 th of June Revolutionary Movement, known as 154, were the largest and best organized of the nearly dozen granted legal recognition by $\mathrm{Dr}$. Bosch in 1963.8 Despite constant secret police harassment during the latter part of Trujillo's regime, the political left had begun to organize secretly. Beginning as early as one half hour after General Riviera's capture, these political organizations mobilized and put large numbers of armed civilians into the streets. Although Reid went on national television and assured the people that he was still in charge, bands of armed youth, Los Tigres ("the Jaguars"), swarmed through Santo Dorningo shooting any policernen they could find.

By Sunday morning, 25 April, conditions in the city approached chaos. III prepared or equipped to combat such a large and well armed opposition, members of the national police abandoned their posts en masse, discarded their uniforms, and either disappeared into the crowds or sought sanctuary with 
Wessin $y$ Wessin's forces in the eastern parts of the city. The Dominican Popular Movement (MPD), one of the smaller but still very active Communist parties, opened gas stations and distributed Molotov cocktails to the crowds. 9 Armed bands of Castroites burned the offices of two right-wing parties, the National Civic Union and the Liberal Revolutionary Party; burned the offices of the anti-Communist newspaper Prensa Libre; and began to erect barricades along major city streets. Meanwhile, the rebel military had moved into the city the night before and established defensive positions at the Duarte Bridge and in many of the local parks. By then they were fully armed with mortars, machine guns, bazookas, and small arms. 10 In a last-ditch effort to gain the support of the military, Reid appointed General Wessin $y$ Wessin chief of the armed forces.

Both Reid and the rebels were concerned about the possibility of U.S. intervention. Before 1000 on 25 April Connett had received inquiries from the rebels and from Reid about the American position. Connett told them that the United States would not intervene at that time to support the government. 11 After speaking by telephone with Connett at the embassy, Secretary of State Rusk became convinced that the Loyalist military, now under Wessin y Wessin's command, would soon join the Reid junta and crush the rebellion without outside assistance.

That same Sunday morning, Bosch, from his home in exile in Puerto Rico, spoke with Jose Rafael Molina Urena. Bosch convinced Molina Urena, a party leader and former president of the Congress, to become the Constitutionalist (rebel) provisional president until he, Bosch, could return to the Dominican Republic. Word of this agreement, and more specifically of Bosch's expected return, soon reached the Dominican armed forces who adamantly opposed any attempt to reinstate Bosch. At 1500 the service chiefs agreed to fight the rebels and adopted the name Loyalist for their cause; that is, loyal to the Reid junta and opposed to the Constitutionalists. Their belated decision to band together and oppose the rebels was prompted more by the growing probability that Bosch would return than by real loyalty to Reid or his junta. 12

The military chiefs' decision to fight the rebels came too late to help Reid. At 1030, rebel forces under the command of Lt. Col. Francisco Caamano Deno stormed the presidential palace and captured Reid. For the time being 
the Loyalist government was without a political leader and General Wessin $y$ Wessin assumed the role as its de facto head of state from his headquarters at San Isidro.

Later that afternoon the Dominican Air Force attacked the rebel-held palace and other positions in Santo Dorningo with rocket and machine gun fire from four vintage P-51 Mustangs. An American journalist, Tad Szulc, reported that as the aircraft attacked, thousands of people took to the streets carrying shards of broken mirrors and tried to reflect the sun's rays into the pilots' eyes. 13 Although one plane was lost during the raid, its loss was credited to machine gun fire, not antiaircraft mirrors. At 1600 the Loyalist navy joined the fight and fired four shells over the palace from a gunboat in the Ozama River.14 The naval gunfire showed the resolve of the navy but inflicted little damage, and the gunboat quickly left the area for a safer anchorage.

Apparently intended to demoralize the rebels, the attacks succeeded only in intimidating the more moderate rebels while strengthening the resolve of the Communists and other extremists within the Constitutionalists' ranks. A group of fifty civilians, who only moments earlier had been part of the mob of Constitutionalist supporters in the streets, sought shelter in the palace during the raid and, seeing Reid, began to shout, "Al pared" (to the wall). Colonel Caamano saved Reid from the mob by hiding him in the basement and later in the evening allowing him to escape. Reid immediately sought refuge among his American friends. The State Department rejected his request for asylum at the American embassy for fear that such a move would be seen as an American alliance with the Loyalists and involve the United States too deeply in the developing situation. At that point, the embassy staff still hoped that the armed forces could recapture the government from the rebels. Reid finally found shelter at a friend's house in Santo Domingo and remained there until June. 15

The Loyalist Dominican military's refusal to support Reid actively precipitated his downfall more than did rebel actions during the first twentyfour hours of the rebellion. Had the Loyalist military acted earlier against the rebels, as both Bennett and Rusk originally expected, the rebellion would probably not have developed into a civil war. With Reid's ouster, Charge Connett telephoned Secretary Rusk and told him that the Dominican 
Revolutionary Party and the Constitutionalist military forces had taken control of Santo Domingo and that "the [Loyalist] military [was] divided, ineffectual and undecided."16 In Washington, Rusk informed President Johnson, who took the news with somber disappointment. Judging from subsequent events, Johnson must have pondered the results of such indecisive action by the Dominican military. If the Loyalist military would not, or could not, protect the Reid government against the pro-Bosch Constitutionalists, what would prevent the rebels from taking control? Earlier on the morning of 25 April the president directed the Joint Chiefs of Staff to prepare for the evacuation of Arnerican citizens from the island. Even as Rusk was briefing the president on the latest reports from the embassy in Santo Domingo, a six-ship carrier task group with Navy Capt. James A. Dare as commodore was already en route to the island from Puerto Rico. Now the discussions in the White House situation room turned to the possibility of armed U.S. intervention to prevent the fall of the Dominican Republic to the rebels and their Cornmunist-inspired cohorts.

\section{The Loss of Law and Order}

Monday, 26 April 1965, was a decisive day in the Dominican Civil War. It marked a transition for the rebels and their Constitutionalist provisional government under Molina Urena. Armed civilians, under the control of the two major Communist parties, outnumbered the original rebel military regulars under Colonel Caamano. Radio Santo Domingo, now fully under rebel control, began to call for more violent actions and for the indiscriminate killing of policemen. In an effort to deter further Loyalist air strikes, rebels seized several air force officers' wives and families and threatened to tie them to the Duarte Bridge so they would be killed if the air strikes continued. 17 At this point Charge Connett had no doubt that the rebels were fully under the control of the Communist-inspired political parties.

At the embassy, Connett, after conferring with Secretary of State Rusk by telephone, refused a request from General Wessin y Wessin, the de facto Loyalist military leader, for U.S. military assistance to crush the rebels. Responding to concerns in Washington about the safety of Americans amidst the rapidly deteriorating conditions in Santo Domingo, Connett began to coordinate 
evacuation plans for 3,500 American citizens living in the city. He continued to inform Washington of the situation and of his feelings that Communists were wresting control of the revolution from the more moderate rebel military leaders. At 1230 President Johnson was briefed by Secretary Rusk, Under Secretary Ball, Special Assistants to the President Thomas Mann and Jack Hood Vaughn, and Ambassador Bennett, recently arrived in Washington from Georgia.18 Armed with the latest situation reports from Connett, they discussed the revolution's changing complexion and the plans to evacuate American citizens.

In Santo Dorningo, fighting intensified on the 27th. (Map 3) Fifteen hundred Loyalist troops from San Isidro fought their way across the Duarte Bridge with tanks and armored cars and secured a strongpoint on the west bank of the Ozama River. Loyalist General Salvador Montas Guerrero, wi th his 700man force from the Mella Camp, located in the city of San Cristobal, fifteen miles west of Santo Domingo, led another, although uncoordinated, attack into the western portions of Santo Domingo. However, neither commander advanced or attempted to make further contact with each other or the rebels af ter the initial drive. The Loyalist Dominican Navy, which up to this point had done little more than remove its ships from the Ozama River, fired three shells at the rebel-held presidential palace and withdrew without inflicting any significant darnage. 19

Rebel forces attacked the national police headquarters at the Ozama Fortress, located on the western bank of the river in the southeast section of the city, and seized another arms cache and 700 prisoners. Another group of armed civilians stormed into the Hotel Embajador and harassed Americans assembled there in anticipation of an evacuation. That incident, occurring without Caamano's knowledge or consent, displayed his loss of control over rebel paramilitary activities and proved to be a major reason for President Johnson's later decision to land the Marines.

Ambassador Bennett returned to the Dominican Republic at 1240 on 27 April with instructions from the president and secretary of state to take charge of the evacuation and to influence the Dominican military to put down the revolt. He was met almost immediately at the embassy by Constitutionalist Provisional President Molina Urena and Colonel Caamano. The two rebel 


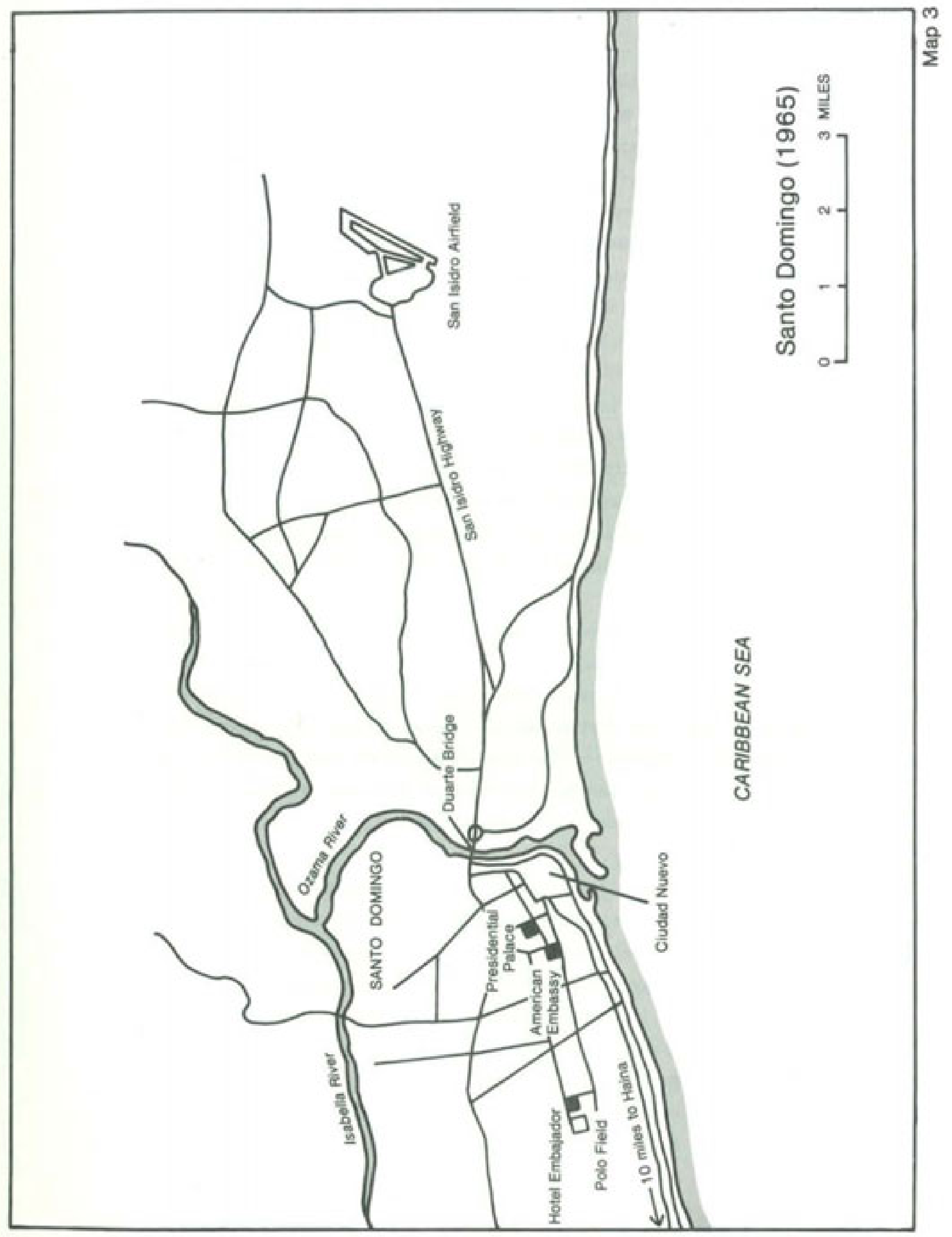


leaders wanted the United States to intercede and stop the Dorninican Air Force attacks. Since Bennett thought the Loyalists were beginning to gain the advantage, a development which he, Rusk, and Johnson would welcome, he refused to intercede. 20 Dismayed by this lack of support, Molina Urena relinquished his leadership of the Constitutionalist provisional government to Colonel Caamano before fleeing to the Colombian embassy, where he was granted political asylum. Two weeks later Caamano reflected on his meeting with Bennett: "We left deeply offended by his [Bennett's] attitude .... We decided to fight on with the people until we had won."2I

At San Isidro, Loyalist generals chose Air Force Col. Pedro Bartolome Benoit to head a new Loyalist junta composed of himself as president, Army Col. Enrique Apolinar Caeado Saladin, and Navy Capt. Manuel Santana Carrasco. 22 Thus, by nightfall on Tuesday, 27 April, a new Loyalist junta had been formed, rebel paramilitary forces had fallen under the control of radical political elements (although Colonel Caamano was now their figurehead leader), and the Loyalists had returned to Santo Domingo, albeit in small numbers and in only two separate areas.

Armed rebel civilians overran the Villa Consuelo police station the following morning, 28 April. The rebels summarily executed policemen who survived the assault but had remained in the station. Other groups of armed civilians ran down and shot on the spot many of those who managed to escape from the police station. 23 The last of the Bosch party moderates broadcast appeals for calm from San Isidro and urged the rebels to cease their attacks. Their appeals were ignored. 24 The Dominican Air Force once again began to strafe and bomb the city.

During the early afternoon of 28 April, Bennett cabled Washington with news of the "collective madness" that had engulfed the city and asked about the possible introduction of armed U.S. forces to protect Americans who had not been evacuated the previous evening by the Marines and, most importantly, to calm the situation in Santo Domingo. Rusk informed Bennett that, for the moment at least, armed intervention was out of the question "unless the outcome is in doubt." 25 The change in Rusk's attitude was founded in large measure on the resumption of Loyalist air attacks. It appeared that these attacks might turn the tide and bring a Loyalist victory without the 
commitment of U.S. troops. That afternoon, the Santo Domingo police chief promised Ambassador Bennett that "the streets would be cleared by nightfall." 26

As soon as the situation appeared to favor the Loyalists, it changed again. By noon, 28 April, rebel resistance and sniper fire directed against the American embassy increased dramatically. Mobs of armed civilians roamed the streets, looting and burning stores and settling old scores against those considered Trujilloite or anti-Bosch. From his office in the embassy, Ambassador Bennett observed the worsening situation and wondered if he had described it clearly to Secretary Rusk. Later that afternoon, after receiving two requests for U.S. forces from the police chief and Colonel Benoit, Bennett again wired Washington: "I recommend that serious thought be given to armed intervention to restore order beyond a mere protection of lives. If the present loyalist efforts fail, the power will go to groups whose aims are identified with those of the Communist Party. We might have to intervene to prevent another Cuba. ${ }^{n 27}$

At 1800 on 28 April, President Johnson approved a Joint Chiefs of Staff plan to land armed Marines in Santo Domingo to reinforce the embassy, protect Americans remaining in the city, and prevent the Dominican Republic from falling to the Communists. He feared that the Dominican Republic would follow the Cuban revolutionary model where a small but dedicated group of activists wrested the revolution from the more moderate factions. An hour later Johnson met with congressional leaders to explain his actions, and at 2015 he made a nationwide television address about the situation in the Dominican Republic. The president told his audience, "Hesitation or vacillation [would] mean death for many of our people as well as many citizens of other lands." 28 At midnight the embassy received a written request for help from Loyalist junta leader Benoit. Several days later, when the $82 \mathrm{~d}$ Airborne Division was ordered to the Dominican Republic, President Johnson referred to Benoit's request as the legal basis for doing so. "Dominican law enforcement and military officials had informed our embassy that the situation was completely out of control and that the police and government could no longer give any guarantee concerning the safety of American or any foreign nationals. ${ }^{\text {29 }}$ 
On Thursday, 29 April, the last day before the 3d Brigade, 82d Airborne Division, deployed to the island, Washington was inundated with reports of continuing violence in Santo Domingo. The Dominican Red Cross estimated that between 1,500 and 2,000 Dominicans had died in the six days since the start of the rebellion and that thousands had been wounded. Ambassador Bennett toured the city that morning and reported to Washington that he saw bodies being burned in the streets and thrown into the sea in Red Cross atteinpts to reduce the spread of disease. 30

That afternoon, in a teleconference between Bennett and Rusk, Secretary of Defense Robert S. McNamara, Under Secretary Ball, Chairman of the Joint Chiefs of Staff General Earle G. Wheeler, and Central Intelligence Agency (CIA) Director William F. Raborn, Bennett relayed information given to him by Msgr. Emanuel Clarizo, the papal nuncio to the Dominican Republic. The nuncio had told Bennett that friends of his in the Dominican Revolutionary Party were worried about their loss of control. The secretary general of the party had been removed and a former chief of the palace guard, a strong supporter of Bosch, had been executed by rebel Cornmunists. ${ }^{31}$ When Rusk asked Bennett if a rebel victory would lead to a Communist takeover, Bennett replied that it would. The ambassador envisioned the rebels installing Bosch for a brief time and then either converting or removing him in favor of a truly Communist regime. ${ }^{32}$ Certainly, the ambassador's feelings about the revolution taking place just outside his window influenced President Johnson's advisers in Washington and reinforced their suspicions about rebel objectives --to return Bosch, but only as a step toward their eventual goal of making the country another Cuba. 33

It was during this teleconference that Ambassador Benniett first suggestegd a plan to interpose U.S. forces between the combatants as an initial step in stopping the violence. Following the sequestering of the rebel forces and a forced cease-fire, the United States would request the Organization of American States to negotiate a political settlement to the civil war. 34 Bennett's plan, well received by the president's military and political advisers, developed into the administration strategy to end the fighting in Santo Domingo and force a negotiated settlement.

At 1930 on 29 April, after meeting with the principals who had just 
finished their teleconference with the embassy in Santo Domingo, Johnson made his decision to employ the $82 \mathrm{~d}$ Airborne Division in addition to the Marines from the 6th Marine Expeditionary Brigade. 35 He was convinced that unless he acted, and acted quickly and overwhelmingly, the Dominican Republic would fall to the pro-Bosch faction and ultimately to communism. Johnson, who from the beginning had wanted the Loyalists to settle the situation, was convinced that they lacked the determination to do so. His decision to allow the Joint Chiefs of Staff to employ whatever forces they deemed necessary to subdue the revolution was based on his desire to end the crisis quickly, prevent a Communist takeover, and reduce the number of casualties on all sides through a massive U.S. military presence. He felt that time was running out.

As the first elements of the $82 \mathrm{~d}$ Airborne Division prepared to depart from Pope Air Force Base, Johnson ordered 1,580 Marines from Commodore Dare's task force ashore to protect the embassy and establish a secure area in its vicinity. This area later became the International Security Zone. As the 82d Airborne Division departed Pope for Ramey Air Force Base in Puerto Rico, the OAS Council debated the situation in Santo Domingo without knowledge of the division's departure. Minutes after the Organization of American States passed a resolution that called for the establishment of an international security zone in Santo Domingo, the first transports carrying the 3d Brigade, 82d Airborne Division, landed at San Isidro Airfield.

\section{The Decision To Intervene}

Since World War II, the United States had attempted to follow a policy of military ronintervention in Latin America affairs. Begun by President Franklin D. Roosevelt's Good Neighbor Policy and strengthened by Kennedy's Alliance for Progress, American policy increasingly relied on economic development assistance and nonmilitary diplomatic pressures to effect changes in the region. However, there were exceptions. The policy toward Latin America had been one of benign neglect, interrupted occasionally by periods of ad hoc crisis response. 36

Kennedy favored the use of diplomatic and economic programs such as the Alliance for Progress rather than military pressure to resolve internal conflicts 
in Latin America, and he became one of the most admired U.S. presidents in the region. Besides Cuba, he had faced challenges in Peru, Argentina, Guatemala, Ecuador, Honduras, and the Dominican Republic and met each through diplomacy, with only the slightest use of military force. When employed, the military was used in an advisory role or as an implicit threat rather than in direct combat. Kennedy's Latin American policy was founded on the principle that relations would be conducted with any freely elected government and that the United States would support these governments against violent overthrow. Although Kennedy had opposed Juan Bosch before he was elected in 1962, he did work with him and was agitated when Bosch was deposed in September 1963.

Despite his showdown with the Soviet Union in the 1962 Cuban missile crisis and his embarrassment at the Bay of Pigs, Kennedy was dedicated to promoting change in Latin America through democratization, cooperation, and economic rewards and punishments. The threat of U.S. force existed, but such force was not used directly. The Alliance for Progress sought to foster modernization through internal development, liberalization, and the spread of democratic principles.

In the early summer of 1965, and under an administration much different from that of Kennedy, the violence in Santo Domingo and the threat of Communist expansion in the Caribbean tested U.S. foreign policy toward Latin America. To quell the violence and meet the perceived Communist challenge, Johnson changed the course of American foreign policy to one of direct military intervention in the Dominican Civil War. Why this departure from the general Latin American policy begun by Roosevelt during World War II? One reason was that Johnson was obsessed with the manner in which history viewed past U.S. presidents. He saw what the Bay of Pigs did to Kennedy and how Eisenhower was criticized for having lost Cuba to the Communists. Johnson refused to take the chance of becoming the president who lost the Dominican Republic: "The last thing I wanted -- and the last thing that the American people wanted -- was another Cuba on our doorstep." 37 Johnson was suspicious of the rebels' true motivation and of Bosch's ability to control the radicals within his Constitutionalist movement if and when he regained power. ${ }^{38}$ Johnson's policy goals toward the Dominican Republic were, in order of importance, to prevent the establishment of another radical Castroite government; to establish a 
stable, democratic, and strongly anti-Communist regime; and to pressure the Organization of American States into creating the machinery for collective action against Communist or radical dictatorial expansion in the region.

Even before the start of the civil war, Johnson's administration took steps to strengthen Reid against Bosch and his left-of-center supporters. Within a month of Reid's inauguration, the island received $\$ 100$ million in American grants and aid. In return, the United States pressured Reid to institute some political and social reforms. Although he attempted to liberalize his country, these same programs contributed to his fall from grace with the military and resulted in his government's collapse just twenty-four hours after the start of the rebellion. 39

Johnson knew there would be an outcry from Latin America against a return to American military intervention. He mistakenly believed, however, that once he established a Communist link to the revolution, the major Latin American governments, which had already demonstrated their disdain for communism by ousting Cuba from the Organization of American States, would lend him their support. "I knew it would attract a great deal of criticism [in Latin America.] . . . we had tried so hard ever since the days of Franklin Roosevelt to overcome the distrust of our neighbors ... . I did not want those days of suspicion to return. ${ }^{440}$

To establish the Communist link, President Johnson turned to his new CIA director, Raborn. Both men hoped that the news media could be used to present this link to Latin America as well as to convince the American people of the impending threat within the Dominican Republic. On Raborn's orders, two CIA lists, "Current Rebels Who Had Cuban Training" and "Rebels Who are Known Leftist Activists," were released to the press from the embassy in Santo Domingo and named fifty-eight Communists or Communist supporters within the rebel movement. 41 Listed beside the names of valid Communist conspirators were the names of several persons only loosely associated with the Communist movement; names were even duplicated within each list. These inaccuracies, and a general public distrust of the CIA's motives in releasing the information, did little to convince either the press or members of the Organization of American States that there was an imminent threat of a Cuban-directed takeover. Despite Johnson's comınents concerning "outside 
influence" at the time the lists were released, doubt was cast over U.S. intentions. Previously, the president had publicly defended his intervention solely on the grounds of protecting life and restoring order; now, he was stopping Communist expansion.

The sudden emergence of the "Communist threat" in a 2 May speech by President Johnson to justify the employment of the $82 \mathrm{~d}$ Airborne Division in the Dominican Republic came too late and with too little evidence to support it. Although 76 percent of the American population initially supported the Marine evacuation operation, less than half supported the introduction of the Army.42 Within the U.S. Congress, a storm of protest began to brew. Powerful blocs in both houses never accepted the introduction of the Army as moral or in the best interests of the United States. J. William Fulbright, Joseph Clark, and Wayne Morse led the opposition in the Senate, with Sam Rayburn leading the opposition in the House. Fulbright took exception with both the intervention and the president's explanation of why it had become necessary. He commented before the Senate Foreign Relations Committee, which he chaired: "[The US] intervened forcibly and illegally not to save lives but to prevent the victory of a revolutionary movement that was judged to be Communist dominated." 43

When the speaker of the House told Johnson that there weren't many "commies" in the Dominican Republic, the president replied that he (Rayburn) "just wasn't looking hard enough." 44 This was the beginning of a long-running feud between the president and Congress -- a feud that would eventually extend to American involvement in Vietnam. Senator Morse reflected the feelings of the congressional opposition to the intervention when he said, "If the United States had limited its actions in the Dominican Republic to rescue operations, merely sending in troops to bring out our civilians, it would not in any way have interfered, even to the slightest extent, with the rights of sovereignty." 45

Debate over the Dominican intervention spread into other areas of foreign policy as well. Walter Rostow, an accomplished political analyst and later member of the National Security Council, described the intervention as being "in substance and timing a rehearsal for the debate on Vietnam." As such, at least for Johnson, the Dominican intervention was the beginning of the loss of presidential credibility and autonomy in foreign affairs. 46 


\section{Notes - Chapter II}

1. Audrey Bracey, Resolution of the Dominican Crisis, 1965: A Study in Mediation (Washington, D.C.: Institute for the Study of Diplornacy, 1980), P. xiv.

2. Luis Iturralde Chinel, La O.E.A. y la Revolucion Dorninicana (Washington, D.C.: Union Panamericana, 1967), p. 26.

3. Ltr, C.I. Saltzman to Sen. William Fulbright, 20 Sep 65, in personal papers of Amb. W. Tapley Bennett, Jr., file 12, box 4416 83D358, U.S. Department of State historical files, Washington, D.C.; Speech, Lt Gen Bruce Palmer, Jr., for AUSA Mtg, Washington, D.C., 11 Oct 66, sub: US Stability Operations in the Dominican Republic, in private papers collection, Military History Institute, Carlisle Barracks, Pa.; Abraham F. Lowenthal, The Dominican Intervention (Cambridge, Mass.t Harvard University Press, 1972), p. 23; Tad Szulc, "When Marines Stormed Ashore in Santo Domingo," Saturday Evening Post, 31 Jul 65, p. 40.

4. Paul E. Smith, "The United States Military Assistance Program in the Dominican Republic 1953-1965: A Lesson Learned?" student essay (Carlisle Barracks, Pa.: U.S. Army War College, 18 Jan 68), pp. 12-13.

5. Frank E. Galati, "Military Intervention in Latin America: Analysis of the 1965 Crisis in the Dominican Republic," student thesis (Ft. Leavenworth, Kan.: U.S. Army Command and General Staff College, 1983), p. 67.

6. Theodore Draper, "The Dominican Crisis: A Case Study in American Policy," Commentary 79 (Dec 65): 38.

7. Lyndon Baynes Johnson, The Vantage Point (New York: Holt, Rinehart and Winston, 1971), p. 187.

8. Iturralde Chinel, Revolucion Dominicana, p. 24.

9. Center for Strategic Studies, Dominican Action - 1965: Intervention of Cooperation (Washington, D.C.: Georgetown University, Jul 66), p. 17.

10. Ibid., p. 14.

11. Ibid., p. 17.

12. Theodore Draper, "The Dominican Intervention Reconsidered," Political Science Quarterly 85 (Mar 71): 7.

13. Tad Szulc, "US to Evacuate Nationals Today in Dominican Crisis," New York Times, 27 Apr 65. 
14. Msg, AMEMBASSY Santo Domingo to SECSTATE, 25 Apr 65, 4:30 P.M., in Bennett personal papers, file 45, box 4417 83D 358.

15. Msg, SECSTATE to AMEMBASSY Santo Dorningo, 29 Apr 65, 5:20 A.M., in Bennett personal papers, file 45, box 4417 83D 358; Center for Strategic Studies, Dominican Action, p. 21.

16. Record of Incoming Telephone Call from Amb. William B. Connett, AMEMBASSY Santo Domingo, 25 Apr 65, 2:00 P.M., National Security Council (NSC) History, Dominican Republic Intervention, LBJ Library, Austin, Tex. 1966), p. 650.

17. John Bartlow Martin, Overtaken By Events (New York: Doubleday,

18. Ibid.

19. Center for Strategic Studies, Dominican Action, p. 27.

20. Bracey, Resolution of the Dominican Crisis, p. xv.

21. Washington Post, 10 May 65.

22. Office of the Joint Chiefs of Staff, "Chronology of the Crisis in the Dominican Republic" (Washington, D.C.: Historical Division, Joint Secretariat, 30 Sep 66), p. 14.

23. Memo, CIA, sub: Addenda Concerning Communist Participation in the Dominican Revolution, NSC History.

24. Center for Strategic Studies, Dominican Action, p. 33.

25. Msg, State to Bennett, AMEMBASSY Santo Dorningo, $281313 \mathrm{Apr} 65$, NSC History.

26. Joint Chiefs of Staff, "Chronology," p. 12.

27. Ambassador Bennett did not recommend approval of Benoit's first request for U.S. forces at 1500 on 28 April but supported his second request later in the afternoon. The local situation was changing very rapidly and began to favor the rebels. Memo, State Dept, $28 \mathrm{Apr} 65$, in Bennett personal papers, file 9, box 4416 83D 358; Richard J. Krickus, The Control of Local Conflict: Case Studies, vol. II: Latin America (Waltham, Mass.: Bolt Bernanek and Newman, Aug 69), p. 165.

28. Melvin H. Johnsrud, "In the Dorninican Crisis, Was Peace Victorious?" student thesis (Ft. Leavenworth, Kan.: U.S. Army Command and General Staff College, 1968), p. 10.

29. M. Margaret Ball, The OAS in Transition (Durham, N.C.: Duke University Press, 1966), p. 471. 
30. Draft white paper, "The Dominican Conflict," p. 9, and speech, Amb. W. Tapley Bennett, Jr., before the Professional Groups Active in Journalism and Foreign Affairs, $17 \mathrm{Sep}$ 65, at Atlanta, Ga., both in personal papers of Amb. Ellsworth Bunker, file: Misc., box 14383 67D291, in U.S. Department of State historical files, Washington, D.C. NSC History.

31. Msg, AMEMBASSY Santo Domingo to SECSTATE, $290515 Z$ Apr 65,

32. Herbert G. Schoonmaker, "United States Military Forces in the Dorninican Crisis of 1965," doctoral dissertation (Athens: University of Georgia, 1977), p. 59.

33. Yale H. Ferguson, "The Dominican Intervention of 1965: Recent Interpretations," International Organization 27 (Auturnn 73): 524-25.

34. Schoonmaker, "U.S. Forces in the Dominican Crisis," pp. 59-60.

35. Tbid.

36. Jack Child, "Post-War U.S. Strategy Planning for Latin America (1945-1976): from 'Rainbow' to 'IDAD'," Rpt presented to Eleventh Military History Symposium, Oct 84, U.S. Air Force Academy, Colorado Springs, Colo. For further information on the history of U.S.-Latin American and Dominican foreign relations, as seen from the liberal left, see Melvin Gurtov, The United States Against the Third World (New York: Praeger, 1974).

37. Johnson, The Vantage Point, p. 198.

38. Ferguson, "Dominican Intervention," p. 524.

39. Draper, "The Dominican Crisis," p. 36.

40. Leslie Andrew Scott, "The Dominican Republic Crisis, 1965: Military Intervention as an Instrument of American Foreign Policy" (Maxwell AFB, Ala.: Air War College, Mar 77), p. 26.

41. Working paper, U.S. Embassy Santo Domingo, sub: Communists Identified as Working in Rebel Movement, in Bennett personal papers, file 9, box 4416 83D358; Center for Strategic Studies, Dominican Action, p. 48.

42. Scott, "Dominican Republic Crisis," p. 21.

43. Galati, "Military Intervention," p. 95.

44. Speech, Pat Holt, former aide to Senate Foreign Relations Committee and Sen. William Fulbright, sub: The Dominican Republic - SFRC Investigation, NSC History.

45. Krickus, Local Conflict, p. 177. 
46. Scott, "Dorninican Republic Crisis," p. 24. 


\section{U.S. Unilateral Actions}

At sunset on Tuesday, 27 April 1965, 1,176 civilians, most of them Americans, began to disembark from a convoy of buses and trucks that had just taken them from the Hotel Embajador in downtown Santo Domingo to the small naval facility at Haina. Behind them, plumes of smoke and sounds of gunfire rose from the strife-torn city. In front of them stood the imposing steel-gray hulls of the U.S.S. Ruchamkin, the U.S.S. Wood County, and helicopters from Marine Helicopter Squadron 264, waiting to take them to safety. As the evacuees began their exodus, the United States entered a period of unilateral intervention in the Dominican Civil War -- a period that lasted until the InterAmerican Peace Force was established in Santo Domingo on 23 May.

This American military intervention, the third during the twentieth century, was significant for three reasons. When President Johnson ordered U.S. forces ashore, he redirected American policy on interventionism in Latin America. From that moment, American foreign policy assumed a more active and direct role than since the days of Franklin Roosevelt and his Good Neighbor Policy. Second, the 1965 intervention involved large U.S. Army combat forces for the first time in a direct combat role in the Caribbean. Finally, the intervention laid the groundwork and the impetus for forming and deploying an intra-regional military force, the OAS Inter-American Peace Force.

Unilateral U.S. military operations encompassed three distinct phases. In the first, the Marine Corps' 6th Expeditionary Brigade, supported by Dare's Naval Task Force 44.9, evacuated civilians on 27 and 28 April. The Army's 82d Airborne Division conducted the second phase, stability operations, from 30 April to 3 May. This phase was marked by often heavy fighting between the rebels and American forces. The establishment of the line of communication on 3 May began the third phase, which lasted until 23 May. This final stage, unilateral peace-keeping, ended when the OAS Act Establishing the InterAmerican Peace Force was ratified in Santo Domingo. Together, these unilateral operations protected American and foreign citizens from the civil war, stopped the fighting in Santo Domingo, and established conditions under which the Inter-American Peace Force could take form and assume its duties. 


\section{Phase I - Evacuation}

Less than twenty-four hours after Connett first notified the State Department that an anti-Reid rebellion had started in Santo Domingo, Dare's carrier task group received orders to steam toward the Dominican Republic. At 1104 on 25 April, Admiral Thomas A. Moorer, Commander in Chief, Atlantic, ordered Commodore Dare to deploy his forces from the Vieques Islands in Puerto Rico to an area southwest of the Dominican Republic and to prepare for the possible evacuation of U.S. citizens from Santo Domingo. By 0200 the following morning the task group, comprised of six vessels and 1,500 Marines, had taken station thirty miles offshore and was preparing to carry out a combined helicopter and sea lift evacuation on order. 1 During the previous year the task group had participated in two amphibious landing exercises at Guantanamo and was well prepared for this mission.

Aboard his flagship, the U.S.S. Boxer, Commodore Dare and Maj. Gen. R. McC. Tompkins, the Marine commander, made final plans for the evacuation. Intelligence Dare received from the Joint Chiefs of Staff neglected to detail the size, composition, or strength of the potential opposition ashore. After examining their options, Tompkins and Dare decided to attempt an unarmed evacuation using both fleet helicopters and surface vessels, while armed Marines aboard ship stood ready if needed. ${ }^{2}$ Meanwhile, on shore, Charge Connett reached an agreement with the chief of the Dominican Navy for U.S. naval forces to have free access to the port of Haina to evacuate civilians. At 1325 on 27 April, Assistant Secretary of State for Inter-American Affairs Jack Hood Vaughn notified General Wheeler that President Johnson had ordered them to implement the evacuation. ${ }^{3}$ Although Wheeler and Johnson had spoken earlier, that Vaughn relayed the president's decision to the Joint Chiefs of Staff highlighted the leading role taken by the State Department throughout the entire intervention.

The president made his final decision to order the evacuation following an incident at the Hotel Embajador where American citizens had been assembling for evacuation since 0600 . At noon a group of twenty to thirty armed civilians, many only teenagers, entered the hotel grounds and, while presumably in search 
of a Loyalist news reporter, lined some of the Americans up against a wall and fired over their heads. As other Americans ran for safety inside the hotel, some of the young rebels followed them inside while others continued to fire into the hotel's upper-level windows from outside. ${ }^{4}$ After arriving in Puerto Rico several days later, one American told the press, "They [the rebels] were delighted that we were so terrified." 5

Although no Americans were injured, the incident sent a wave of fear through the crowd. Connett echoed that fear in a strong cable to Washington. His cable reflected grave concerns about the safety of the Americans and the general disintegration of law and order in Santo Dorningo. President Johnson read the message and sent word to the joint chiefs to begin the evacuation.

When Dare received the order to execute, he dispatched two transport vessels and a flight of Marine helicopters to the designated embarkation site at Haina, the Dominican Navy's main facility. Under national police guard, Americans and other foreigners who so desired were taken by truck and bus convoy to Haina, seven miles west of Santo Domingo, to await evacuation. 6 The movement was without incident, thanks to arrangements Connett had made with both factions the previous evening. At the same time the convoy was arriving in Haina, helicopters from the Boxer transported unarmed Marine pathfinders to secure the dock area and establish a helipad. The Ruchamkin and Wood County came into port and the evacuation began. By 1640, 27 April, the evacuation was completed. Six hundred twenty people were sea lifted from the port, and an additional 556 were airlifted to the Boxer and $\underline{\text { Raleigh. }}{ }^{7}$ After the last civilian had boarded, the Marines left Haina for their ships and all the evacuees were transferred to a ship bound for Puerto Rico. This operation removed approximately one-third of all U.S. citizens residing on the island.

The next morning, 28 April, fighting continued to escalate in Santo Domingo, and once again American civilians and other foreigners began to congregate at the Hotel Embajador. At 1745 Ambassador Bennett, who had returned to Santo Dorningo the previous day, asked Commodore Dare to evacuate the new arrivals and reinforce the Marine guard at the embassy. 8 Responding to the ambassador's request and to Joint Chiefs of Staff directives that he cooperate fully with the embassy, Dare ordered a Marine battalion landing team (approximately 560 officers and enlisted men) ashore. (Map 4) 
Under the command of Col. George W. Daugherty, two Marine companies went ashore at Haina and proceeded the ten miles along the coastal highway to the polo grounds adjacent to the Hotel Embajador. By 1830 the Marines had established another helipad at the hotel. 9

During this movement the first American soldier and Dominican civilian were killed. Only four blocks from the hotel, a rebel sniper, firing from a house along the route of advance, fatally shot a Marine walking behind a tank. During the subsequent attack on the house, a hand grenade wounded a five-year-old child inside. The Marines took the child to the hotel aid station, where she died. 10 That night, 684 more civilians were airlifted to the Boxer.

In a national television address that same evening, President Johnson announced that armed Marines had landed in Santo Dorningo to protect the lives of Americans and other foreign nationals seeking evacuation. What the president did not mention was his desire that the Marines would also be able to influence the course of the rebellion. More than protecting American evacuees and the embassy compound, Johnson committed the Marines with the hope that the presence of armed U.S. forces would bolster morale among the Loyalists and demoralize the Constitutionalists. As an additional benefit, the Marines also guaranteed U.S. forces on the ground should the president feel compelled to deploy the $82 \mathrm{~d}$ Airborne Division to the growing battle in Santo Dorningo.

The president was satisfied with the evacuations and reinforcement of the area in the vicinity of the American embassy. The Marines had conducted the two operations smoothly and with minimum force, losing but one man to sniper fire during the movement from Haina to the polo grounds. 11 Johnson, always concerned with his public image, was also pleased when polls indicated that public opinion in the United States favored the evacuation operation. World reaction, especially from Latin America and the Organization of American States, also favored his handling of the evacuation, and what little opposition existed was generally mild. The very nature of world reaction to the Marine intervention may well have figured in his later decision to commit the $82 \mathrm{~d}$ Airborne Division on 30 April. Now that the Marines were firmly in place in Santo Dorningo, Johnson expected the Loyalists to take the initiative and crush the revolution. The two successful evacuations and the reinforcement of the embassy ended phase one of the operation. 


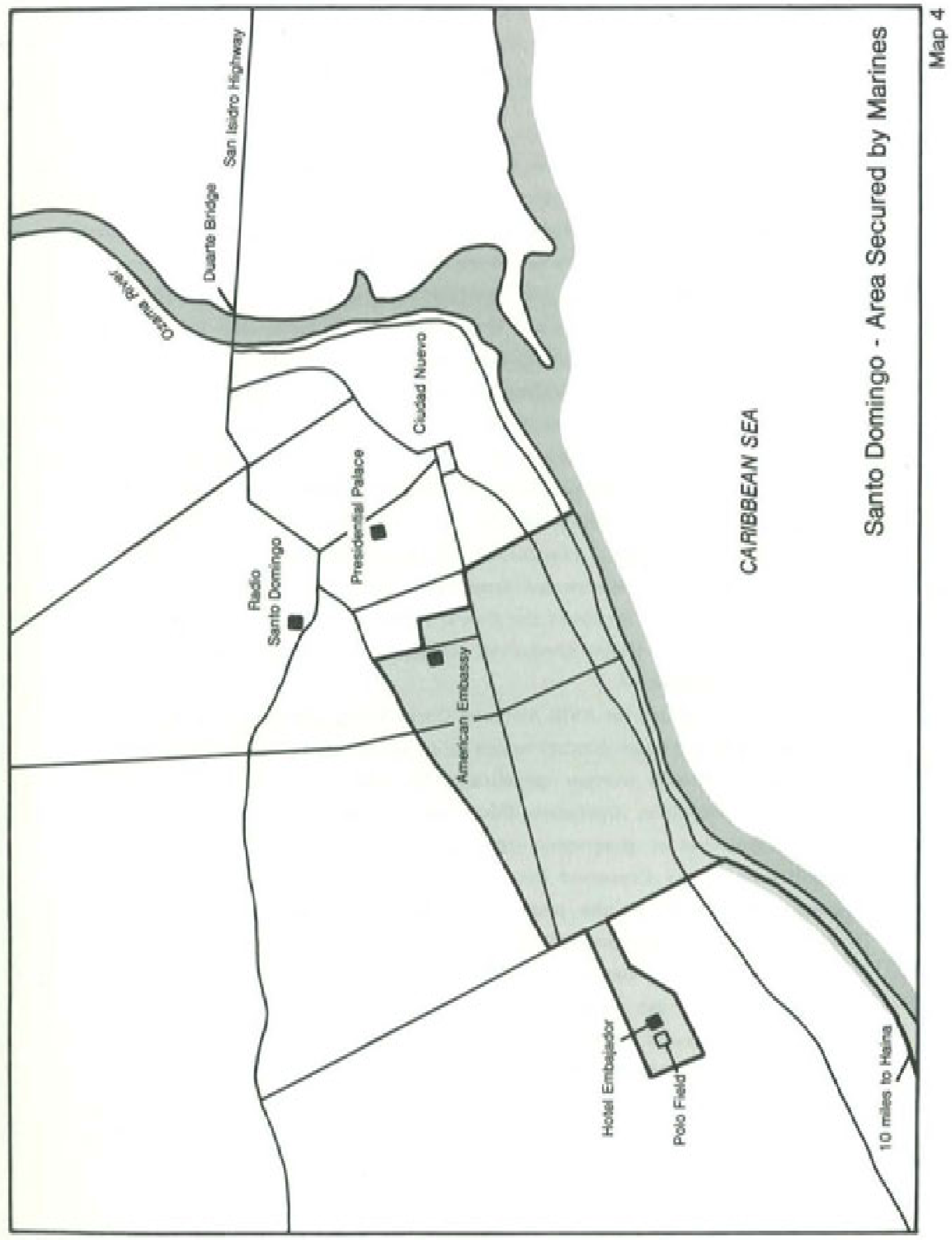




\section{Phase II - Stability Operations}

Stability operations, the second phase of the intervention, began when two battalion combat teams from the 3d Brigade, 82d Airborne Division, arrived in the early morning hours of Friday, 30 April. Now the military planners faced their own problems, many of which were spawned from an out-of-date operation plan and misplaced priorities.

The $82 \mathrm{~d}$ Airborne Division's deployment to the Dominican Republic was based on Commander in Chief, Atlantic, Operation Plan 310/2, originally formulated during Rafael Trujillo's last days in power. The plan was revised in 1963 shortly after the ouster of Dr. Bosch, when President Kennedy sent a merno to Secretary McNamara asking, "How many troops we could get into the Dominican Republic in twelve hours, in twenty-four hours, thirty-six, or fortyeight hours."12 The revision included several options ranging from shows of naval force to blockades, evacuations, and troop deployments to Puerto Rico before finally landing Marine and Army forces in the Dominican Republic itself. Once the joint chiefs approved the plan and designated it OPLAN 310/2-63, the Army and Marine Corps conducted annual mobility exercises accordingly, commencing in 1964.13

The plan called for XVIII Airborne Corps headquarters to be activated and for two Army battalion combat teams to be air-dropped northeast of San Isidro Airfield. Although written specifically for just such a contingency in the Dominican Republic, Operation Plan 310/2-63 had not been updated with current political or geographic information. On the night of 26 April, U.S. Continental Army Command notified XVIII Airborne Corps by telephone to prepare to implement the plan and to place the lead element of the $82 \mathrm{~d}$ Airborne Division, designated POWER PACK I, on Defense Condition 3.14

General York, commander of the $82 \mathrm{~d}$ Airborne Division, had two major problems during the early phases of preparing his division for combat -communications and a routine exercise, Operation BLUE CHIP. After receiving the order from XVIII Airborne Corps to begin preparations for possible deployment, he experienced delays in the retransmission of his orders through the Commander in Chief, Atlantic. For instance, he did not receive the change 
in readiness condition order through command channels until an hour and a half after Fort Bragg had received an information copy directly from the Joint Chiefs of Staff. 15 The problem of timely information through the Atlantic command was never fully resolved. Once the division and XVIII Airborne Corps headquarters were firmly entrenched in the Dorninican Republic, they established communications directly to the joint chiefs via $\mathrm{C}-130$ Talking Bird aircraft, of ten bypassing the Atlantic command entirely. For the duration of the Dorninican operation, critical information went directly from Washington to Santo Domingo, with only administrative communications following formal channels through the Atlantic command.

The division and its Air Force support were to participate in Operation BLUE CHIP, an annual training exercise scheduled to commence in mid-May. The joint chiefs' failure to cancel it once the Dominican situation began to deteriorate delayed the division's readiness for deployment by several hours. At the time when orders were given to increase the division's level of readiness, no decision was forthcoming on the fate of BLUE CHIP. By the time the exercise was cancelled, it was midnight on $28 \mathrm{April}$, and thirty-three aircraft had to unload BLUE CHIP equipment and reload with the division's combat equipment. 16

At 1630 on Thursday, 29 April, as fighting between Loyalists and Constitutionalists continued to escalate, the Joint Chiefs of Staff designated General York commander of U.S. ground forces. Shortly thereafter, Atlantic command ordered him to deploy POWER PACK I, the division's 3d Brigade, to Ramey Air Force Base in Puerto Rico. There the brigade would make final preparations and await orders to proceed with the planned airdrop in the vicinity of San Isidro Airfield. 17 The layover at Ramey was more for political than military reasons, originally designed as a show of intent to force the situation in Santo Dorningo. Proposed by the State Department and accepted by the joint chiefs and President Johnson, this show of force was intended to resolve the situation without engaging American troops in combat.

Secretary of Defense McNamara and the Joint Chiefs of Staff began discussions on whether to air-drop or airland the brigade when diplomatic traffic from Santo Domingo indicated that the situation was reaching crisis. McNamara and General Wheeler were concerned that the Loyalists might not be 
able to hold out until morning. Strike Command and the Atlantic command were opposed to changing the airdrop because of foreseen overcrowding at San Isidro and the lack of heavy equipment needed to unload aircraft already rigged for airdrop. 18 At 1910, General Wheeler asked Vice Adm. Kleber S. Masterson, commander of Joint Task Force 122, for intelligence about San Isidro -- was the airfield operational and, if so, was it still controlled by Loyalist forces?

Masterson dispatched a helicopter from the Boxer to find General Wessin $\mathrm{y}$ Wessin, last reported to be at the polo grounds. Instead of Wessin $y$ Wessin, whose whereabouts seemed a mystery, Masterson's men found General Imbert, commander of the Dominican National Police. General Imbert boarded the helicopter and was taken to the ship. Imbert told Masterson that although San Isidro was still in Loyalist hands, no one manned the tower after dark. This information was relayed to Washington, where General Wheeler decided to change the operation. Delays in the division's departure and rising concerns that, as General Wheeler told the vice J-3, "[the] whole thing was going to fold up on us unless we could get some troops in. If we wait ... we might not have anything to support," certainly influenced his decision. 19 General Wheeler ordered the brigade to bypass Ramey and to airland at San Isidro. This final change of plan was not made, however, until General York and the 3d Brigade were airborne and rigged for a combat jump. The eleventh-hour change of plans proved fortunate because it was later dicsovered that the proposed drop zone, northeast of San Isidro, was covered with sharp coral outcroppings that would have caused many casualties. 20

At 2130 , only slightly more than two hours after being asked for information about the San Isidro Airfield, the Commander in Chief, Atlantic, informed Masterson that the $82 \mathrm{~d}$ Airborne Division was being diverted from Ramey directly to San Isidro. The admiral immediately sent his aide and two Marine captains to the airfield. 21 Arriving at San Isidro, the three officers found Loyalists holding the airfield and, once convinced that the Dominicans would not interfere, told them of the division's impending arrival. They opened the control tower, turned on the runway lights, and talked down the first planes as they arrived. It was indeed fortuitous to move the three officers to San Isidro since the initial POWER PACK element did not contain an Air Force arrival control group. 
With the three American officers in the tower and an Air Force brigadier general orbiting aboard a Tactical Air Command EC-135 airborne command post, providing communications and flight vectors to the approaching aircraft, the first plane carrying General York and the initial combat elements of POWER PACK I landed at San Isidro at 0216 on 30 April. 22 During the next few hours, forty-six aircraft delivered two battalion combat teams from the $82 \mathrm{~d}$ Airborne's 3d Brigade to San Isidro, and the paratroopers began the arduous process of off-loading rigged equipment by hand. Men attempted to find their heavy equipment (much of which ended up in Puerto Rico), off-loaded aircraft, and avoided the C-130 propellers. Ramp space at the airfield was so crowded that planes were kept taxiing in circles awaiting room to unload. The remainder of the aircraft in the flight, unable to land because of limited space at the airfield, were diverted to Ramey. 23 The Atlantic command staff had foreseen the overcrowding problem and had presented it as a major argument to General Wheeler during discussions about changing the operation from airdrop to airland. Since the problem was anticipated, however, procedures for handling the overflow were included in the change of orders that Atlantic command relayed to both Masterson and York at 2130 on 29 April. Later, as space became available at San Isidro, the remainder of POWER PACK I and the rest of their equipment were shuttled to the island from Ramey.

General York, having assured himself that progress was being made at the airfield, helicoptered to the Boxer to confer with Admiral Masterson and Commodore Dare about the brigade's ground advance into Santo Domingo. They developed a plan that envisioned a battalion-size advance from the airfield to secure the Duarte Bridge and establish a strongpoint controlling the western approach to the bridge. This move would form a line running northeast from the embassy area to the Ozama River. The Marines in the embassy area would hold the left flank, Loyalist troops would form the center, and the division would hold the right flank. The plan was simply to divide the city in half. Before dawn, they presented the plan to Ambassador Bennett and received both his and President Benoit's approval.24 At daybreak, under the cover of Marine F-4 Phantoms from Puerto Rico, the 1st Battalion, 508th Infantry, moved along the San Isidro Highway and secured the eastern approach to the Duarte Bridge, the city's only link to the east. Meanwhile, 1st Battalion, 505th Infantry, 
established a security perimeter around the airfield and sent patrols into the adjacent countryside. 25

The men of Company C, Ist Battalion, 508th Infantry, crossed the bridge and established a six-block beachhead on the western bank of the Ozama River that included the city's main power station. The $82 \mathrm{~d}$ Airborne Division also controlled the Villa Duarte section east of the bridge and San Isidro, which served as the division's staging area. In the western part of Santo Dorningo, 1,700 Marines held the area around the American embassy and controlled the coastal highway leading from the city to Haina. That night the $3 \mathrm{~d}$ Battalion, 6th Marines, expanded the area around the embassy to encompass several other diplomatic missions. In accordance with an OAS resolution, this area became the International Security Zone. (Map s)

Unfortunately, the virtual disappearance of Loyalists from the center of the defensive line damaged the otherwise well planned and executed operation. When American troops appeared on their flanks, Loyalist forces made an unannounced and totally unexpected retreat across the Duarte Bridge to the Armed Forces Training Center at San Isidro Airfield. The gap they left remained open for another three days.

As the brigade began to move toward Santo Domingo, it confronted the first of many peculiarities it would have to deal with while in the Dominican Republic. Since both the Loyalists and the rebel, or Constitutionalist, regulars wore the sarne uniforms, an immediate problem becarne recognizing who was who. An imaginative U.S. officer suggested that the Loyalists wear their caps sideways or backwards. The idea not only worked but, as described by an eyewitness, "provided a comic twist" at the start of the operation. 26

As the first day progressed, York requested four additional battalion combat teams from the Joint Chiefs of Staff to reinforce the 2,500 paratroopers already on the island and permission to close the gap between the Army and Marines. Although the joint chiefs approved the request for the battalions, they could not secure President Johnson's approval for General York to advance across Santo Domingo to close ranks with the Marines. The president was concerned that the additional show of force would hurt the United States within the Organization of American States, where debates on the intervention were in progress. The OAS Council had taken a generally 


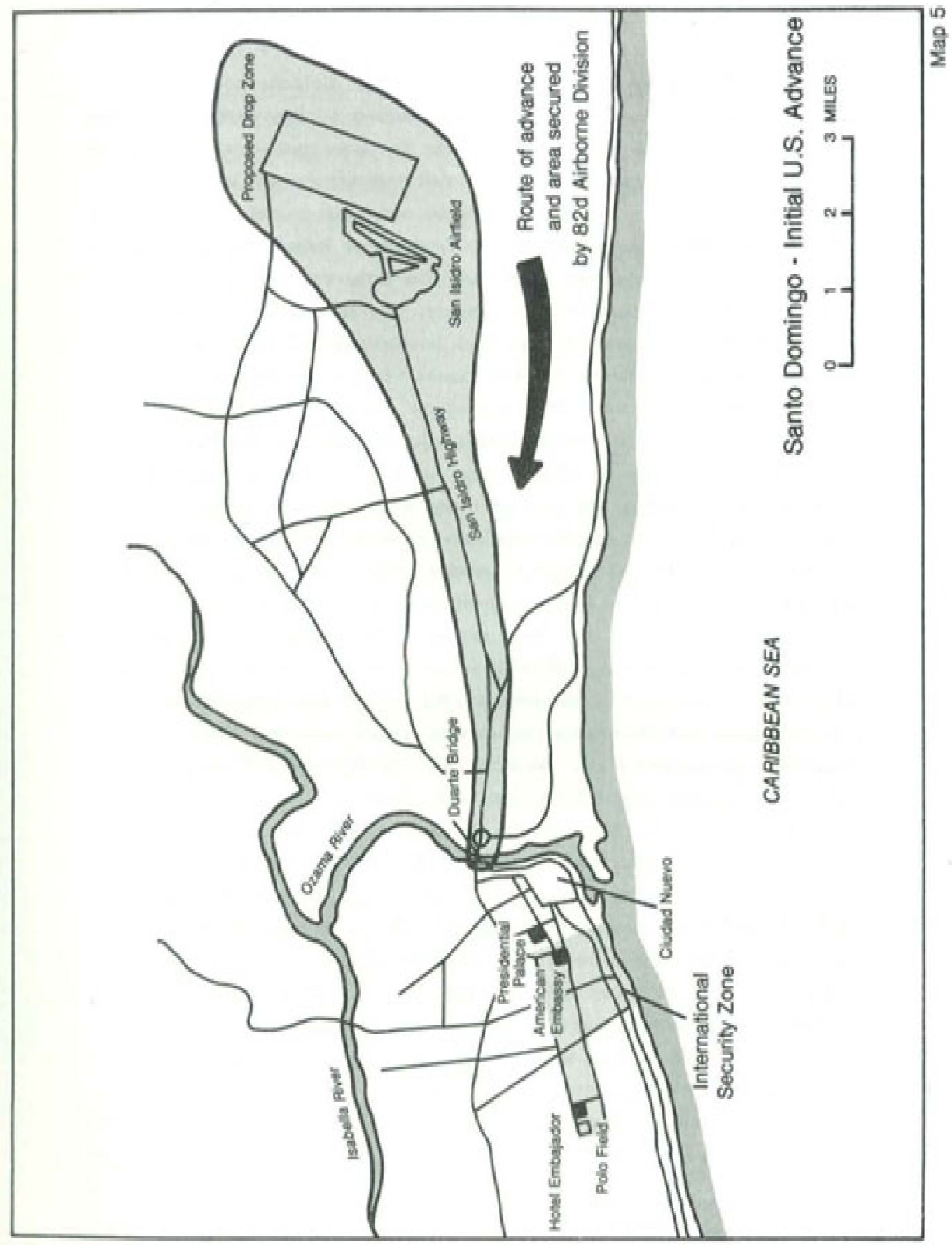


hostile position toward the introduction of the division, and presidential advisers feared that any overt American action at this early time could jeapordize efforts to gain OAS approval for later unilateral or coalition operations. General York would have to wait until the morning of 3 May to see his plan employed. There also existed concerns among the president's diplomatic advisers, particularly forıner Ambassador John B. Martin, that such an early and aggressive act could turn the intervention into an American version of the Soviet occupation of Hungary. The Joint Chiefs of Staff agreed that the operation could be postponed temporarily and would benefit from having more troops there to secure the areas. Thus began the trend that would continue throughout the entire operation. Military considerations were subordinated to State Department concerns for restraint and world opinion. 27

By the afternoon of the first day, Ambassador Bennett wired the State Department requesting the first of many shipments of emergency medical supplies and equipment for the population of Santo Dorningo. The 15th Field Hospital, 307th Medical Battalion, medical detachments, and an ambulance company were dispatched almost immediately from Fort Bragg. 28 Accompanied by emergency supplies of food, these medical units were placed in the division's second deployment package (POWER PACK II) ahead of several combat units. Even at this early stage of the operation, the military was being used to achieve political goals and was required to act with restraint and neutrality, at least in regard to humanitarian aid. Medical care and food were distributed to all Dominicans without regard for political affiliation.

Even before the $82 \mathrm{~d}$ Airborne Division had been on the island for one complete day, President Johnson felt the sting of OAS condernnations. Having made the decision to intervene, the president wanted the military phase of the stability operation completed quickly and with a minimum of public outcry. Johnson met with the secretaries of state and defense and, according to one eyewitness, told them that he did not intend "... to sit here with my hands tied and let Castro take that island .... I know what the editorials will say, but it would be a hell of a lot worse if we sit here and don't do anything and the communists take that country." 29 To make sure that the Dominican problem was solved rapidly, he instructed General wheeler to "get enough force down there to do the job quickly and overwhelmingly," and told him to get the "best 
general in the Pentagon" to command the forces in Santo Domingo. 30

Wheeler turned to Lt. Gen. Bruce Palmer, Jr., to command U.S. Forces, Dominican Republic. Paimer, then Army deputy chief of staff for operations, was on orders to take command of the XVIII Airborne Corps the following month. Operation Plan $310 / 2$ called for the activation of the XVIII Airborne Corps headquarters, and General Palmer's preparation to assume command of the corps, plus his assignment as deputy chief of staff, contributed toward his selection. Palmer learned that he would have at his disposal whatever combat forces he needed, including the 101st Airborne Division, to stabilize the situation in Santo Domingo. General Wheeler emphasized that the operation was as much political as military when he instructed Palmer that he would have to work closely with Ambassador Bennett; in fact, as Wheeler said, they (Palmer and Bennet $t$ ) "would have to work as a team." 31 Palmer also learned of his unstated mission, one given to Wheeler by the president earlier in the day. This mission was to "prevent the Dominican Republic from going Communist. The president," Wheeler told Palmer, "has stated that he will not allow another Cuba .... You are to take all necessary measures ... to accomplish this mission." ${ }^{n 32}$

While Palmer was en route to the island, the Joint Chiefs of Staff directed that the 2d Brigade, $82 \mathrm{~d}$ Airborne, still at Fort Bragg, be placed on Defense Condition 2. The remainder of the division, as well as the entire $101 \mathrm{st}$ Airborne Division, was placed on condition 3, and the 4 th Marine Expeditionary Brigade was ordered to Santo Domingo froin Camp LeJeune. 33 This move brought the number of U.S. troops in the continental United States on alert for the Dominican Republic to over 24,000 men. ${ }^{34}$

Just before midnight on 30 April, Palmer arrived in Santo Domingo and went directly to the embassy to confer with Ambassador Bennett. The situation in Santo Domingo had continued to deteriorate. Rebels had captured Fortress Ozama, a national police stronghold, seizing large quantities of arms and ammunition. They also captured Radio Santo Domingo, a facility they would use effectively throughout the conflict. Loyalist troops under command of General Wessin $y$ Wessin had retreated across the Duarte Bridge to San Isidro Airfield and were demoralized. Of the 30,000 Dominican soldiers, airmen, and police at the start of the civil war, General Wessin y Wessin now 
commanded less than 2,400 troops and only 200 national police, or about 15 percent of the original force. 35 With the exception of the two American controlled sections of the city, the area surrounding the American embassy and the stronghold near the bridge, the rebels controlled Santo Domingo.

On 1 May, U.S. forces under the command of General Palmer were involved in the largest buildup in the history of American military intervention in Latin America. The Joint Chiefs of Staff dedicated all Air Force assets not supporting Southeast Asia to the Dominican Republic. An air bridge was established between Pope and San Isidro, with a transport from the 19th Air Force landing in the Dominican Republic on an average of every five minutes. In the first fourteen days of the intervention, the Air Force flew 1,538 sorties that delivered 14,650 personnel and their equipment to the island. As each aircraft returned to the continental United States, it was refueled, reloaded, and returned with a new flight crew to San Isidro. 36

By Tuesday, 4 May, only five days after the first arrival of the division, U.S. troop strength onshore (including Army, Marine, and Air Force) rose from 4,200 to over 17,000 . The arriving forces included the remaining two brigades of the 82d Airborne Division, the 5th Logistic Command (later Group), the 7 th Special Forces Group, and several psychological warfare organizations, both military and Department of State, which together comprised POWER PACK 1IV. Outside the Dominican Republic, the Air Force deployed two fighter and reconnaissance squadrons to Ramey in Puerto Rico: eighteen F-100 fighters from the 353d Tactical Fighter Squadron, twelve F-104s from the 331st Fighter Interceptor Squadron, and six RF-101 and three RB-66 reconnaissance aircraft from the 363d Composite Reconnaissance Unit. 37 Their mission was to watch for and interdict any Cuban arms shipments. 38 In Santo Domingo, U.S. Forces, Dominican Republic, grew on 5 May with the inclusion of all Marine forces onshore. Thus was established the command relationship that continued throughout the operation. (Chart 1 )

General Palmer was concerned about the gap left between American lines when the Loyalists withdrew. The gap allowed the rebels to move freely throughout the city and gave them the opportunity to fortify Ciudad Nuevo, their stronghold in Santo Domingo. By closing the opening, Palmer hoped to divide the rebel territory, isolate Ciudad Nuevo, and restrict the flow of 
Chart 1 - Command Relationship, U.S. Forces

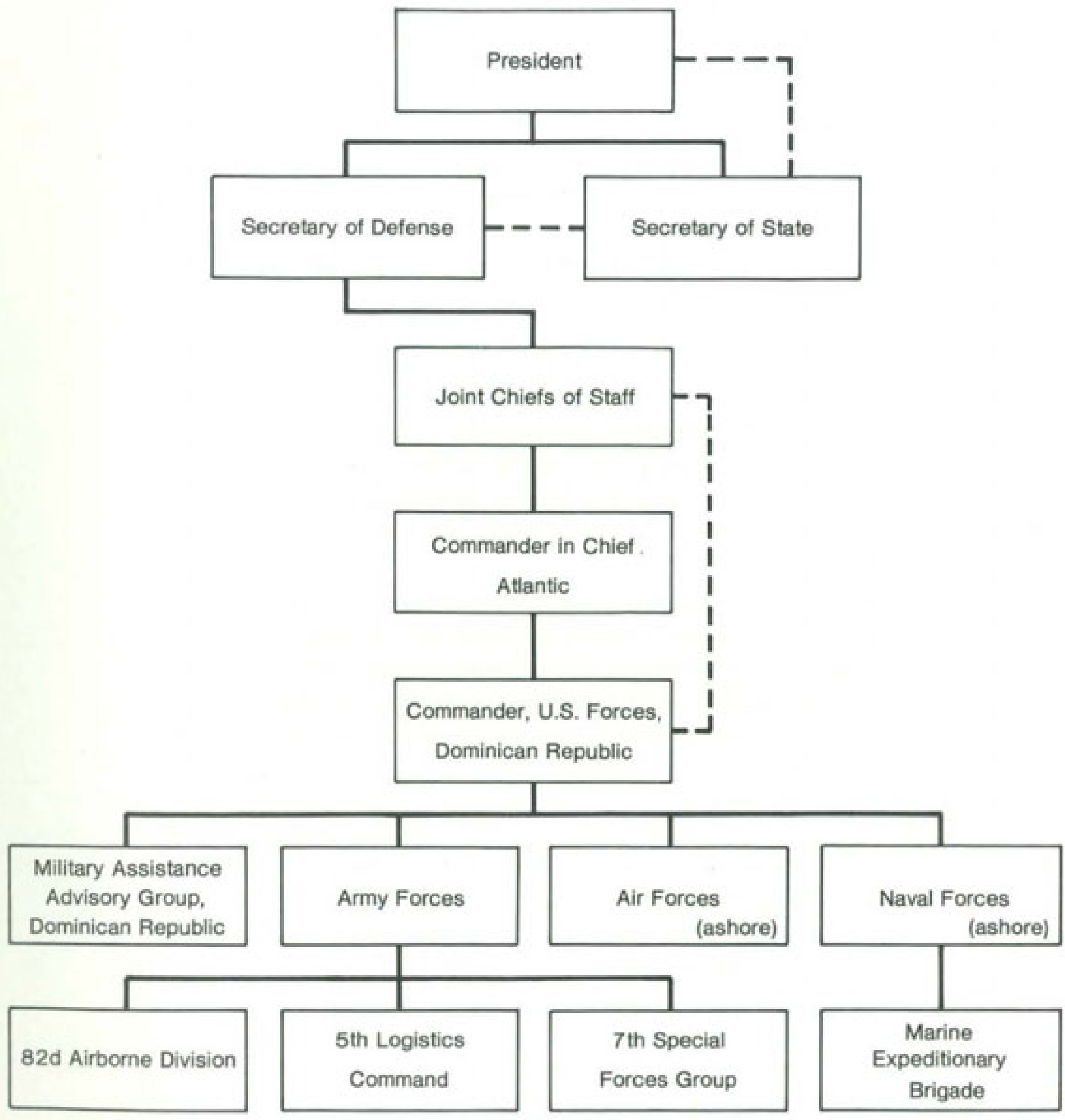


armaments. In addition, he hoped that presenting a solid line of defense would demoralize the rebels and bolster the Loyalists. On Saturday, 1 May, after proposing his plan to unite his forces in Santo Domingo to the director of the Joint Staff, Palmer ordered York to send a reconnaissance patrol from the Duarte Bridge, along Calle Concepcion, to see if contact could be made with the Marines in the International Security Zone, a distance of slightly more than two and a half kilometers. Two platoons from Company C, 1st Battalion, 508th Infantry, completed the mission but took seven casualties -- two killed and five wounded by rebel fire. However, the company's success in reaching the Marine positions prompted Palmer to ask the joint chiefs' permission to close the gap permanently. ${ }^{39}$ In an open telephone conversation between General Palmer in Santo Domingo and General Wheeler and President Johnson in Washington, the president approved Palmer's plan with the proviso that Palmer first obtain OAS concurrence. Palmer was instructed to base his request to a five-member OAS special committee (formed on 1 May by the OAS Council to oversee conditions in Santo Domingo) on the grounds that it would provide a land route for resupply and evacuation from the International Security Zone to the airfield at San Isidro. 40

Since 30 April, the OAS Council and the Tenth Meeting of Ministers of Foreign Affairs, in session at the Pan American Union in Washington, had been forums for bitter denunciations of U.S. interventionism. Debates were now turning toward finding means to reduce U.S. military presence through the possible formation of a unified OAS military force. Although resistance remained strong, Ambassador Bunker made slow but steady progress toward such a force. However, both he and President Johnson feared that another unannounced unilateral action, such as closing the gap, might kill their chances.

In Santo Domingo, General Palmer met with OAS Secretary General Jose A. Mora and the special committee on Sunday, 2 May. After a brief and cordial discussion relating to the benefits and low risks anticipated in such an operation, General Palmer received their permission to establish the line of communication. At one minute past midnight on the morning of 3 May, three U.S. infantry battalions left the bridge and leapfrogged toward the security zone. The first battalion advanced one-third of the way and held, allowing the other two battalions to pass through its line. The second and third battalions 
repeated this procedure until at 0112 they made contact with the Marines at Calle San Juan Bosco and Calle Rosa Duarte. By avoiding known concentrations of Caamano's forces, the operation succeeded against minimal resistance, united American forces, and trapped 80 percent of the rebels south of the line. 41 In only one hour and eleven minutes the four-block-wide line of communication was established. (Map 6) At dawn two infantry companies traversed the corridor without incident, and the nickname All American Expressway emerged.

The establishment of the line of communication paved the way for a settlement to the civil war. The corridor not only provided a route for supplies and communications between the two American camps but, most importantly, cut the city in half, isolating the majority of the rebels in Ciudad Nuevo and in a small enclave north of the Duarte Bridge on the Ozama River. With the exception of the small area north of the line, Caamano's rebel forces were contained to the south and east. Similarly, the Loyalist forces were kept to the north and west of the rebel area and across the river to the east. With U.S. forces between the combatants, rebel military aspirations to expand beyond Ciudad Nuevo withered, and the Loyalists, whose morale had greatly improved with the arrival of the $82 \mathrm{~d}$ Airborne, could not attack the rebel stronghold south of the American-held line. For the United States, the corridor provided the opportunity to act more impartially to achieve a political settlement since the U.S. troops would not permit the Loyalist forces to defeat the rebels militarily. 42 The successful American military initiative allowed President Johnson to concentrate on the search for a political solution.

\section{Phase III - Unilateral Peace-Keeping}

With Santo Domingo divided by U.S. forces, General Palmer emphasized assistance to the people of the city and support to U.S. and OAS diplomatic efforts. By Tuesday, 4 May, he had at his command twelve infantry battalions (nine Army and three Marine) and would soon be given control over the 41 member Military Assistance Advisory Group and the Air Force's Joint Air Traffic Coordinating Center that managed the air bridge into San Isidro. ${ }^{43}$ Now the need for support and logistic units began to escalate. During the next week, 


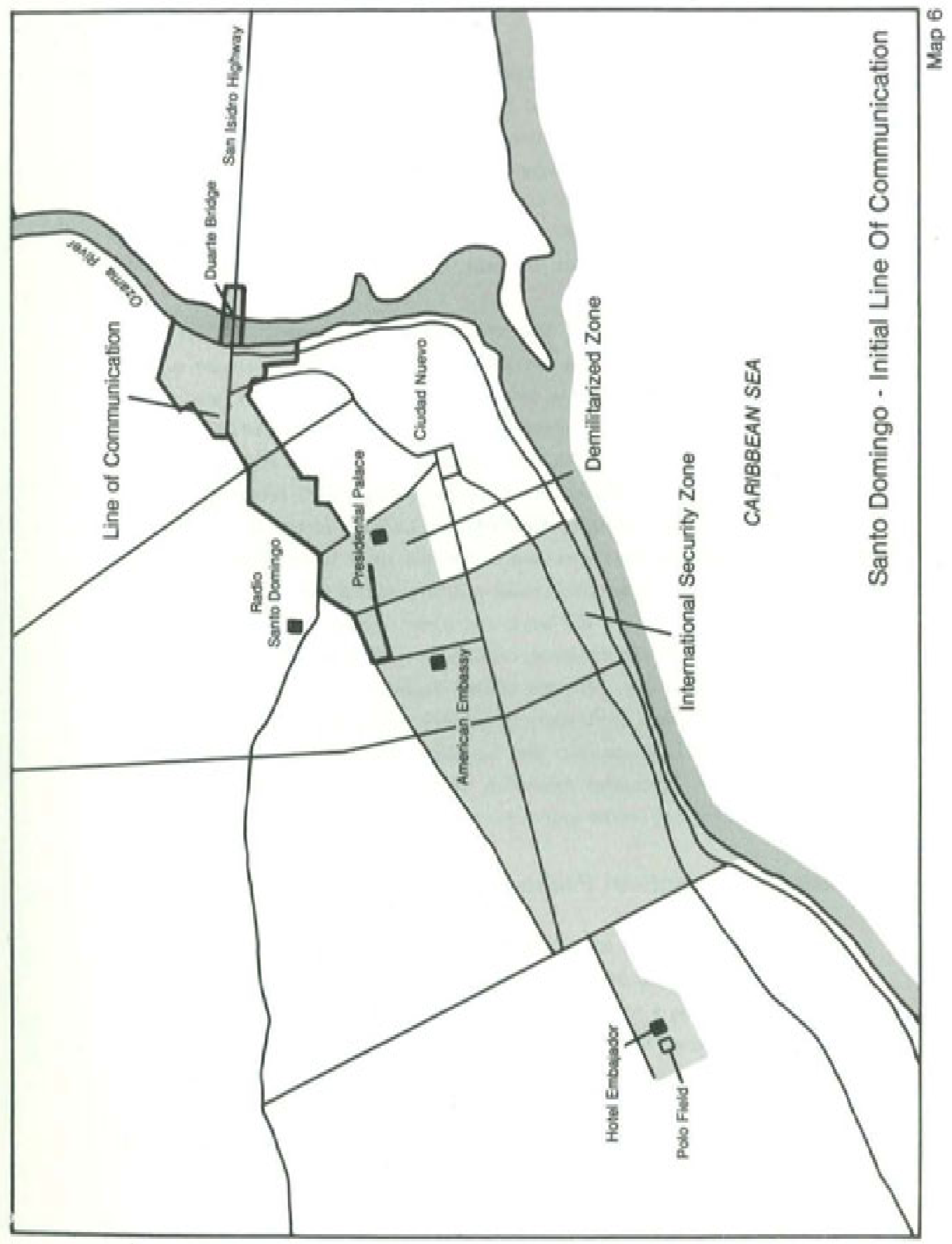


military police, quartermaster, finance, ordnance, and supply and salvage units arrived. Aircraft from Pope delivered some 30.7 million pounds of supplies during May. 44 But even while troops continued to arrive in the Dominican Republic, discussions about withdrawals were taking place in the White House.

As early as 6 May, just eight days after General York and POWER PACK I landed at San Isidro, Special Assistant to the President for National Security Affairs McGeorge Bundy proposed token troop withdrawals. Bundy felt this would assist Ambassador Bunker's mission of finding support for the formation of an inter-American force. 45 Bunker used the first withdrawals to prove the sincerity of U.S. intentions and to serve as a lever for the inter-American force. His suggestion that additional U.S. troops would be withdrawn if OAS troops replaced them allowed Latin governments to support a multinational force on the grounds that, by doing so, they would hasten the removal of U.S. combat troops from a neighbor's soil. Since the Marines were traditionally the most visible American military symbol throughout Latin America, the Joint Chiefs of Staff ordered them withdrawn first.

Meanwhile, at the XVIII Airborne Corps headquarters in the old Trujillo residence in Santo Domingo, General Palmer turned his attention to stemming the flow of armaments into the rebel area and returning the city to some degree of normality. He realized the importance of restraint and issued orders placing numerous restrictions on the rules of engagement. He also decided that the vast majority of his artillery support could be withdrawn. The artillery, which had fired but eight illumination rounds during the very first night of operations before being ordered to cease for fear of starting fires, would not fire again during the intervention, and, except for one battery, all division artillery was removed by the end of May.46 The division started information programs and published a daily news bulletin for the troops to help them understand why they were there and thus prevent incidents between them and often hostile rebel-inspired crowds. Coupled with Palmer's ever-increasing emphasis on restraint and fire discipline, the education program proved invaluable to the negotiation effort.

With the relative calming of emotions in Santo Dorningo, the first major step toward an eventual settlement occurred on 5 May when Colonels Benoit and Caamano and the OAS special committee signed The Act Of Santo 
Domingo. The colonels represented the Loyalist and Constitutionalist factions, and the five members of the special committee represented the Meeting of Foreign Ministers and the Organization of American States. Proposed by the committee, the act provided for a general cease-fire, recognition of the International Security Zone, agreement to assist relief agencies, and the sanctity of diplomatic missions; above all, it set a framework for later negotiations. 47 The one thing the act did not do was stop all the fighting. Occasional sniping continued against U.S. forces in the security zone and line of communication, as did attacks on patrols that strayed into rebel territory. However, major battles between the Dorninican factions subsided, at least for the time being.

On Friday, 7 May, the president of the Supreme Court of Justice, Dr. Julio Cuello, swore in a new junta headed by General Imbert (former Ambassador Martin's personal choice for the job) and three distinguished civilians: Alejandro Zeller Coco, a civil engineer; Carlos Grisolia Poloney, a lawyer; and Julio D. Postigo, a writer and editor who had published Juan Bosch's latest book about his rise to and fall from power. 48 The new junta replaced the Benoit Loyalist government and was an attempt to form a more broadly based government intended to gain public support and distance itself somewhat from the military. Although associated with the military, Imbert was the sole survivor from the Trujillo assassination and retained a great deal of popular support. The junta, named the Government of National Reconstruction, received U.S. recognition and began to reorganize the leadership of the Loyalist armed forces. Commodore Caminero became the minister of the armed forces, General Wessin y Wessin became the head of the army, and General Jesus de los Santos Cespedes replaced Wessin y Wessin as commander of the San Isidro facility. 49

On 13 May Loyalist General Imbert suddenly broke the peace that had settled over the city. In an attack that took the United States completely by surprise, he moved against rebel forces located north of the line of communication and against rebel-held Radio Santo Domingo. During the attack, U.S. troops shot down one of the new government's five P-51 Mustangs when it accidentally strafed their position. Although Ambassador Bennett lodged a complaint with OAS representatives, the offensive actually 
accomplished several U.S. goals and was strikingly similar in design and concept to Operation Plan STRIKE BREAKER, developed and approved by the U.S. commander in the Dominican Republic but never implemented. 50 It eliminated pockets of resistance outside Ciudad Nuevo and temporarily silenced Radio Santo Domingo before government commandos put it off the air the following day. 51

As long as Imbert's forces remained north of the line of communication, Palmer did not interfere with their actions against the rebels. In retaliation, rebel forces attacked the U.S.-held power station but were soundly defeated by a squad of paratroopers holding that position. 52 The campaign ended on 21 May when the new government's forces reached the line of communication to the south and the Ozama River on the east, thus effectively removing rebel opposition north of the line. (Map 7) The resulting cease-fire lasted until the rebel offensive of mid-June.

This cease-fire, accompanied by the near total separation of cornbatants by the line of communication, marked the beginnings of true neutrality for U.S. Forces, Dorninican Republic. Despite pulic announcements of neutrality from the start of the intervention, U.S. actions had overwhelmingly favored the Loyalist cause. Now, in the unilateral peace-keeping phase, the military could treat both sides equally while diplomats sought to resolve the civil war through negotiation. This American shift was both successful and noticed, for on 22 May Colonel Caamano told OAS Secretary General Mora that he now considered U.S. troops neutral. He announced that he would negotiate with American representatives, but not with Imbert. 53

The peace-keeping mission continued and grew. With the relatively stable military situation after 21 May, General Palmer placed greater emphasis on civil affairs, humanitarian aid, and neutrality. These humanitarian efforts supported the United States and Organization of American States as peacekeepers trying to help a neighbor and facilitate negotiation. Special Forces, who arrived in the Dominican Republic on 4 May (D plus 4), were sent into the countryside where they established six detachment sites and assisted aid programs, gathered intelligence on popular feelings and rebel resistance, and looked for signs of Cuban involvernent. In addition to these more routine activities, the Special Forces' eighteen officers and sixty-seven enlisted men 


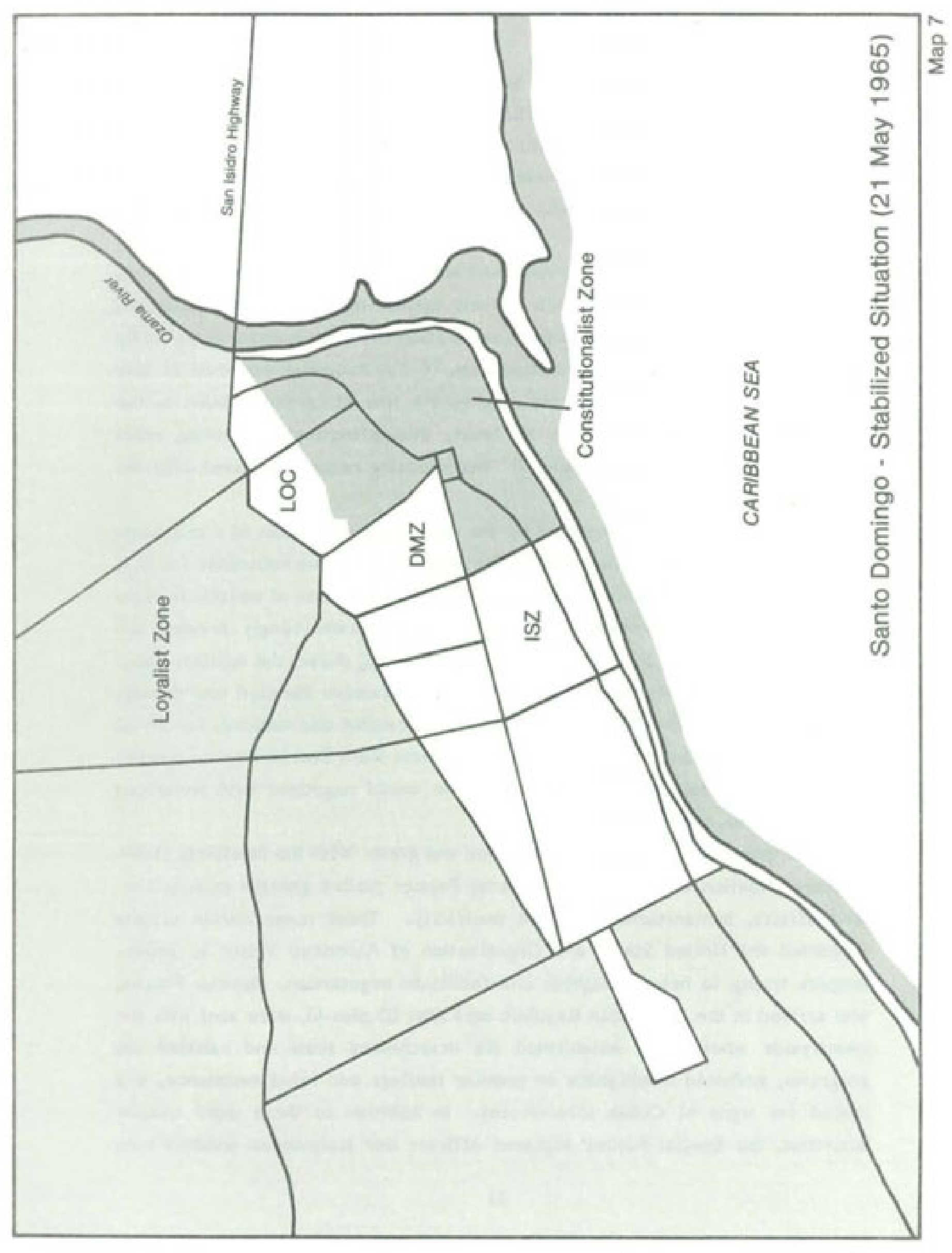


performed several special missions. On 19 October they located, seized, and detained Constitutionalists operating an underground pro-rebel newspaper, Patria. On 23 October they reinforced Juan Bosch's personal bodyguard at his residence and after 12 January 1966 maintained surveillance on his activities. And on 17 January they covertly moved the family of Dominican Col. Montes Arache from its home in Puerto Plata, on the northern shore, to Santo Domingo. 54 Except for inflammatory broadcasts from Radio Havana, no solid evidence of Cuban involvement with material aid to the rebels was uncovered. Throughout the operation, the Dominican campesinos, farmers and countryfolk, remained relatively unconcerned over the violence in Santo Domingo.

Meanwhile, in the city, U.S. soldiers settled into a routine of normal garrison life and peace-keeping duties in the line of communication and International Security Zone. They assisted relief agencies in restoring public services and utilities and in distributing food and medical supplies.55 Checkpoints to control access into and out of Cludad Nuevo were manned around the clock and stemmed the flow of arms and of Loyalists into the rebel stronghold. Soldiers who only weeks earlier had been met with rocks and snipers' bullets began to see smiles and signs of appreciation from the population of Santo Domingo.

General Palmer ordered the line of cornmunication boundary expanded on 5 May to protect U.S. troops from sniper fire. (Map 8) Shortly thereafter, the International Security Zone expanded eastward to encompass the French embassy. General Palmer coordinated the movement in advance with both the Organization of American States and Colonel Caamano, and it was not opposed.56 The situation in Santo Domingo had indeed begun to calm. U.S. presence had forced a stalemate, and with each passing day rebel resistance decreased. Their military initiatives had been lost. Any victories they achieved would have to come from negotiation and compromise, not from armed conflict.

In just three weeks U.S. armed forces changed the entire outlook of the Dominican rebellion. Overwhelming American combat forces had separated the combatants and forced a military stalemate. 57 President Johnson and his key political advisers successfully used controlled, overwhelming force to prevent the establishment of another Castro-type regime in the region. The application 


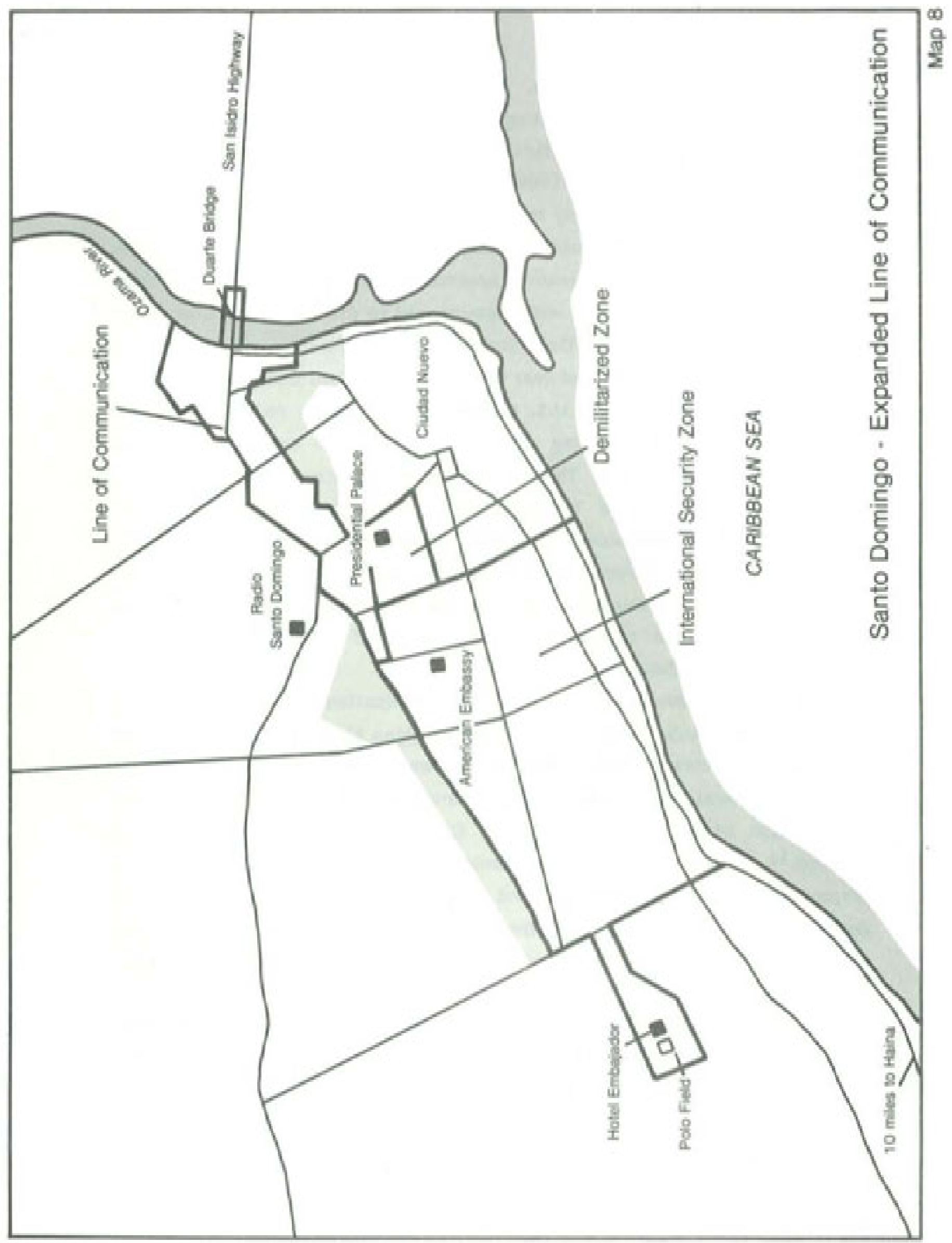


of a disciplined, restrained force, capable of shifting its neutral position so as to complement political negotiations, was rapidly bringing a violent situation under control. Indirectly this application of force also provided an impetus for the formation of the Inter-American Peace Force. The assumption of peacekeeping operations by Latin troops would allow for the withdrawal of U.S. forces. Had not the Army been present, there is little reason to believe that the Organization of American States would have acted in any concerted military manner to resolve the situation in the Dominican Republic. Unilateral American military actions laid the foundation upon which the Inter-American Peace Force could be established and operate in an atmosphere of relative calm and stability. 


\section{Notes - Chapter III}

1. Washington Center of Foreign Political Research, National Support of International Peacekeeping and Peace Observation Operations, vol. V (Washington, D.C.: Johns Hopkins University, Feb 70), p. 253.

2. James A. Dare, "Dominican Diary," Proceedings (Dec 65): 38.

3. Msg, State to JCS, $2711725 Z$ Apr 65, National Security Council (NSC) History, Dominican Republic Intervention, LBJ Library, Austin, Tex.

4. Ltr, AMEMBASSY Santo Domingo to SECSTATE, 13 Jun 65, sub: Shooting Incident at the Hotel Embajador on April 27, in personal papers of Amb. W. Tapley Bennett, Jr., file 11, box 4416 83D358, U.S. Department of State historical files, Washington, D.C.

5. "Evacuees Arrive, Tell of Terror," New York Times, 29 Apr 65.

6. Merno, White House for Bundy, 6 May 65, sub: Dominican Republic Task Force Meeting -- Decisions Taken, NSC History, p. 4; Washington Center, National Support, p. 254.

7. R. McC. Tompkins, "Ubique," USMC Gazette 49 (Sep 65): 34.

8. Dare, "Dominican Diary," p. 42.

9. Herbert G. Schoonmaker, "United States Military Forces in the Dominican Crisis of 1965," doctoral dissertation (A thens: University of Georgia, 1977), p. 58.

10. Tad Szulc, "14 Marines Are Wounded," New York Times, 1 May 65.

11. Abraham F. Lowenthal, The Dominican Intervention (Cambridge, Mass.: Harvard University Press, 1972), p. 123.

12. Schoonmaker, "U.S. Forces in the Dominican Crisis," p. 12.

13. Ibid., p. 86.

14. Speech, Lt Gen Bruce Palmer, Jr., for AUSA Mtg, 26 Oct 66, Washington, D.C., sub: U.S. Stability Operations in the Dominican Republic, in private papers collection, U.S. Army Military History Institute, Carlisle Barracks, Pa.

15. Speech, Lt Gen Bruce Palmer, Jr., for AUSA Mtg, 11 Oct 66, Washington, D.C., sub: U.S. Stability Operations in the Dominican Republic, in Palmer private papers. 
16. Edward E. Mayer, "The Dominican Crisis - 1965," student thesis (Carlisle Barracks, Pa.: U.S. Army War College, 8 Apr 66), p. 32.

17. Ibid.

18. Department of the Army, Office of the Chief of Staff, "Stability Operations Dominican Republic," pt. 2, vol. IV (Washington, D.C.: Department of Army, 28 Jun 71), pp. 90-91.

19. Palmer speech, 11 Oct 66.

20. Mayer, "The Dorninican Crisis," p. 32.

21. Msg, CINCLANT to CJTF 122, $300230 \mathrm{Z}$ Apr 65, NSC History; Tompkins, "Ubique," p. 36.

22. Department of the Army, "Stability Operations," p. 93.

23. Ibid.

24. Tompkins, "Ubique," p. 36.

25. U.S. Forces, Dominican Republic, "Report of Stability Operations" (Santo Domingo: HQ, USFORDOMREP, 31 Aug 65), Incl 4 to ch. 4; Elbert E. Legg, "The U.S. Military Role in Coping with a Sudden Revolt in the Dominican Republic," student thesis (Carlisle Barracks, Pa.: U.S. Army War College, 4 Jan 68), p. 6; Department of the Army, "Stability Operations," p. 94.

26. Eldredge R. Long, Jr., "The Dominican Crisis 1965: An Experiment in International Peace Keeping," student thesis (Newport, R.I.: U.S. Naval War College, 1967), p. 39.

27. Yale H. Ferguson, "The Dominican Intervention of 1965: Recent Interpretations," International Organization 27 (Autumn 1973): 530.

28. List of Assignments, U.S. State Dept, 1 May 65, NSC History, p. 3.

29. John Bartlow Martin, Overtaken by Events (New York: Doubleday, 1966), p. 662.

30. Oral History, Gen Bruce Palmer, Jr., Military History Institute, Carlisle Barracks, Pa., p. 155.

31. Ibid., p. 154.

32. Frank E. Galati, "Military Intervention In Latin America: Analysis of the 1965 Crisis in the Dorninican Republic," student thesis (Ft. Leavenworth, Kan.: U.S. Army Command and General Staff College, 1983), p. 85; Palmer oral history, p. 152. 
33. Barry M. Blechman and Stephen S. Kaplan, Force Without War (Washington, D.C.: Brookings Institute, 1978), p. 314.

34. Lowenthal, The Dominican Intervention, p. 116.

35. Paul E. Smith, "The United States Military Assistance Program in the Dominican Republic 1953-1965: A Lesson Learned?" student thesis (Carlisle Barracks, Pa.: U.S. Army War College, 18 Jan 68), pp. 12-13; Martin, Overtaken by Events, p. 64.

36. USFORDOMREP, "Report of Stability Operations," Incl 1 to ch. 4; Department of the Army, "Stability Operations," p. 36.

37. Aerospace Studies Institute, "The Dominican Republic Crisis of 1965: The Air Force Role," AU-434-66 (Maxwell AFB, Ala.: Air University, Dec 66), pp. 28-29.

38. Department of the Army, "Stability Operations," p. 42.

39. USFORDOMREP, "Report of Stability Operations," p. 9; Robert F. Barry, ed., Power-Pack (Portsmouth, Va.t Messenger Printing Co., 1982), p. 24.

40. Palmer oral history, p. 167; Galati, "Military Intervention," p. 88.

41. USFORDOMREP, "Report of Stability Operations," pp. 9-10; Palmer speech, 11 Oct 66, p. 5.

42. Palmer speech, 11 Oct 66, p. 5 .

43. Washington Center, National Support, p. 261.

44. "The Dominican Intervention 1965" (Carlisle Barracks, Pa.: U.S. Army War College, 1984 ), p. 9.

45. Action Memo, White House for Bundy, 6 May 65, sub: Committee Meeting, Dominican Republic Task Force, NSC History, p. 2.

46. Long, "The Dorninican Crisis," p. 41.

47. Organization of American States, Tenth Meeting of Consultation of Ministers of Foreign Affairs, "First Report of the Special Committee of the Tenth Meeting of Consultation of Ministers of Foreign Affairs," doc. 47 (Washington, D.C.: Pan American Union, 1965), pp. 14-15; Act of Santo Domingo, reprinted in The OAS Chronicle 1 (Washington, D.C.: Pan American Union, August 1965): 28-29.

48. Luis Iturralde Chinel, La O.E.A. y la Revolucion Dorninicana (Washington, D.C.t Union Panamericana, 1967), p. 65.

49. Ibid., p. 66 . 
50. Long, "The Dominican Crisis," p. 56; Schoonmaker, "U.S. Forces in the Dominican Crisis," p. 167.

51. Msg, USCOMDOMREP to CINCLANT, 1423112 May 65, NSC History; USFORDOMREP, "Report of Stability Operations," p. T-1.

52. Richard W. Mansbach, ed., Dominican Crisis 1965 (New York: Facts on File, 1971), pp. 60-65.

53. Ibid., p. 81.

54. Department of the Army, XVIII Airborne Corps, "Stability Operations Report, Dominican Republic (Part III) (Ft. Bragg, N.C.: HQ, XVIII Airborne Corps, 1 Oct 65), p. V1-1; Palmer oral history, p. 172.

55. Before the operation ended in 1966, U.S. Army doctors treated 58,000 Dominican citizens for ailments that covered the spectrum of routine and emergency medical care. Memo, Palmer to Bunker, 27 Nov 65, sub: Support for Provisional Government, in personal papers of Amb. Ellsworth Bunker, file: Provisional Government, Political Matters, box 14384 67D291, U.S. Department of State historical files, Washington, D.C.; Schoonmaker, "U.S. Forces in the Dominican Crisis," p. 154.

56. Chronology, U.S. Department of State, NSC History, p. 36; Mansbach, Dominican Crisis, p. 28.

57. Dr. Lawrence Yates, Combat Studies Institute, Fort Leavenworth, Kansas, is currently producing a study which will examine U.S. Army tactical operations in depth. This study is expected to be available in 1987. 


\section{The Inter-American Peace Force}

\section{Toward an Inter-American Force}

Just as a commander maneuvers his forces on a battlefield to seize objectives, so diplomats at the Organization of American States sought strategic positions through debate and behind-the-scenes pressure to reach theirs. Never before had the organization established a combined military force to quell internal unrest in a neighbor state. The birth of such a force was not easy, as it involved a myriad of political questions and required Latin nations to overcome long-standing opposition to military intervention by themselves or especially by the United States. For these reasons, an examination of the process which resulted in the Inter-American Peace Force, in which the United States was the major participant, is just as important as operations undertaken by the coalition force once it was in the Dominican Republic.

As American forces were landing in the Dominican Republic, Latin American nations were in the midst of general economic and political expansion. Trade patterns were shifting from the dominant north-south axis that had existed since the late nineteenth century to a more balanced one that included east-west trade as well. ${ }^{1}$ Brazil, Argentina, Venezuela, and Mexico were emerging as significant economic powers through development of their natural resources, primarily oil and foodstuffs, and, accompanied by military growth, they became the region's de facto political leaders. Coupled with an expanding view of a political world that included more than the two superpowers, and a realization of the importance and practicality of regional geopolitics, these nations challenged the traditional twentieth-century role of the United States as the hemisphere's uncontested political leader. 2

This difference of perspective was crucial in the establishment of the Inter-American Peace Force, a one-time experiment that played an important role in the Dominican Civil War and in subsequent U.S.-Latin American relations. Bitter anti-American rhetoric in the OAS demonstrated to Washington that Latin American countries were changing their view both of their own position in the world and of their relationship with the United States. 
While President Johnson knew there would be some resistance to an intraregional military force in Latin America, the amount of anti-American comments within the Organization of American States and the general reluctance to form the force was surprising to a man accustomed to getting his way in politics.

\section{Initial OAS Debates}

Differences in perception of national threats posed by instability, Communist influence, and the fear of a reeınergence of unilateral U.S. intervention differed greatly between Washington and capitals in Latin America. These differences set the stage for the OAS debates of late April and May 1965. Latin American governments tended to define political instability in somewhat broader and less drastic terms than did the United States. Accustomed to periodic outbreaks of violence as an institutional part of their political systems, they did not feel so threatened by the revolution in Santo Domingo as did the U.S. State Department. In fact, the vast majority of the OAS delegates seated in the Pan American Union represented governments that had initially come to power through violence rather than through the ballot box.

Communist expansion was indeed a matter of regional concern but one that each government treated differently. While all the OAS members in 1965 viewed communism as a potential threat to the peace and security of the region, many governments drew a distinction between communism and liberal social modernization. In the Dominican Republic, even the most modest internal progress toward social liberty and a more equitable distribution of property would seem a dramatic step leftward by comparison to the Trujillo regime. Despite President Johnson's persistent references to Communist control of the Dominican Constitutionalist movement, few Latins became converts to his theory that a return of Juan Bosch would threaten their individual countries. Even those who did accept the "Communist connection" were unsure whether that threat was greater than, or even equal to, their perceptions of the Yankee threat.

During the late 1950s, John Dreier, then U.S. ambassador to the Organization of American States, addressed the issue of diverging perspectives 
on the threat of communism within the region: "Fear of U.S. political domination, rather than any sympathy with communism, has been a reason for the reluctance of the OAS on various occasions . . . to take a stronger position against Communist infiltration and subversion. Defense against communism is recognized as desirable; but this does not, in the Latin American view, justify the risk of opening the door to U.S. political domination." ${ }^{13}$

In Latin America, initial reactions to the landing of the Marines on 27 and 28 April ranged from tacit support and approval (Panama) to shock and indignation (Argentina), with many nations between the two extremes. Despite these early feelings and OAS approval for the Marines to establish the International Security Zone, the introduction of the $82 \mathrm{~d}$ Airborne Division brought censure from the OAS Council. The common thread among the members was that the right of intervention belonged solely to collective actions taken by themselves through the OAS Consultation of Foreign Ministers. ${ }^{4}$

The organization was outraged that the United States had not consulted the council before deploying the 82d Airborne Division. Secretary of State Rusk's argument to Venezuelan President Betancourt before the 6 May vote on the Inter-American Peace Force, that the United States had acted so as to prevent the fall of yet another Cuba through inaction, fell on deaf ears. ${ }^{5}$ Latins who accepted the Marine evacuation of noncombatants from Santo Domingo could not allow the introduction of the Army into the civil war to go unchallenged. Likewise, the often used American rebuttal that the unannounced intervention was necessary because of the slowness of OAS debating and action was a position built on air. In 1962 the organization had debated the Cuban issue and expelled Cuba in just twelve hours. Furthermore, in the Dominican Republic, the Army was already on the ground at San Isidro before Ambassador Bunker ever mentioned the possibility of their introduction.

As Marines prepared to evacuate American citizens from the docks at Haina on 27 April, Ambassador Bunker approached the Inter-American Peace Commission, a standing commission of the OAS Council chaired by the Uruguayan ambassador -- an outspoken critic of U.S. policy -- and called for the first debates on the situation in the Dominican Republic. ${ }^{6}$ Although the commission met, all debate concerning the deteriorating conditions in Santo Dorningo was passed to the full OAS Council, scheduled to meet the next 
morning. 7

Another, and perhaps more immediate, cause for not informing the OAS Council of the planned U.S. military intervention was the real fear of its being rejected out of hand. At the time that the president made the decision to commit the $82 \mathrm{~d}$ Airborne Division, Ambassador Bunker did not believe that he could deliver the necessary two-thirds vote. ${ }^{8}$ At least by following the sequence that occurred, Rusk and Bunker had time to find support for the unilateral actions while debates took place in the Pan American Union in Washington.

Other OAS members demanded answers from the United States to several important questions before they would lend their support to any proposed regional military force. Had the "Johnson Doctrine" replaced Kennedy's Alliance for Progress and Franklin Roosevelt's much-applauded Good Neighbor Policy? Was Johnson cornmitting the United States to a policy of unilateral military interventionism without regard for the OAS charter or Latin sensitivities? It fell to Ambassador Bunker to answer these questions before the OAS Council.

During the morning session on 28 April, Bunker, who neither requested military assistance nor mentioned the possible introduction of additional American troops, explained that the Marines' sole mission was to save lives. Later, this omission haunted U.S. efforts. That evening the United States requested another special session of the council for the following day and succeeded in having the issue raised before the Tenth Meeting of Foreign Ministers in accordance with Articles 39 and 40 of the OAS charter. That body is the highest council of the organization and the only one empowered to act militarily against a member state.

Before the Meeting of Foreign Ministers could convene on the 30 th, OAS Secretary General Mora received distressing news from the papal nuncio and dean of the diplomatic corps in Santo Domingo, Monsignor Clarizo: "The situation is very serious. Both sides would favor prompt assistance from the OAS." 9 The monsignor added that he was attempting to achieve a cease-fire. This information led the council to pass its first resolution on the Dominican situation. The resolution called for a cease-fire and the establishment of the International Security Zone in the diplomatic section of the city, which the 6 th 
Marines already had secured. The vote, sixteen to zero with four abstentions (Chile, Uruguay, Mexico, and Venezuela), came in the early hours of Friday, 30 April, with the council adjourning at 0200 , just minutes before the first plane carrying General York and the 82d Airborne Division landed at San Isidro. Late that morning Monsignor Clarizo and Ambassador Bennett negotiated a ceasefire - the first of many - but, as was of ten to be the case, it was violated almost immediately. 10

U.S. diplomatic efforts intensified before the foreign ministers that same day, with Ambassador Bunker calling for the transfer of military responsibility to the Organization of American States while making it clear that the United States reserved the right to protect its citizens "in a situation of anarchy."11 Bunker reaffirmed the necessity for the American actions and asked the organization to provide the vehicle by which Dorninicans could reestablish a viable and stable government. President Johnson bolstered the ambassador by requesting that OAS representatives be sent to the island to pave the way for a return to the constitutional process and by dispatching Ambassador-at-Large Averell Harriman to meet with political leaders throughout Latin America. In addition, Johnson pledged American support for OAS actions and hinted at Communist influence within the rebellion. 12 When the president addressed the nation that night, he was certain that anti-Communist sentiments filled the country, the Congress, and the Organization of American States. When he stated, "People trained outside the Dominican Republic are seeking to gain control," he surely was aiming his comments at the organization as well as at the American public. ${ }^{13}$ No doubt, President Johnson was hoping to rekindle the anti-Communist feelings that had resulted in Cuba's expulsion in 1962.

Unswayed by the president's speech and concerned by reports of the continuing buildup of U.S. Army troops in Santo Dorningo, the Meeting of Foreign Ministers launched another attack on Ambassador Bunker and the intervention. Led by Venezuela, Chile, and Mexico, the ministers denounced the United States for violating the OAS charter and expressed deep concern over American unilateral action. ${ }^{14}$ Bunker responded with arguments based on the right for self-defense of a country's nationals and on the collapse of law and order in Santo Domingo. He failed to convince anyone of American motives but took the opportunity to cosponsor a Mexican resolution that called for the 
formation of an OAS special committee charged with fact-finding, negotiation, and humanitarian assistance. 15

That Mexico both condemned U.S. actions and proposed exactly what Bunker wanted was oddly consistent with Latin political thought. Mexico felt a strong obligation to denounce U.S. intervention for any reason but shared a deep concern over communism within the region. Thus, as was true with many countries, Mexico accompanied its public condemnations with more discreet expressions of support. Without this dichotomy between public statements and private actions, diplomatic progress within Latin America would not have been possible.

On 1 May, the OAS Meeting of Foreign Ministers formed a special cominittee and empowered it to seek a cease-fire, to ensure that evacuations of civilians went unimpeded, and to investigate the situation in Santo Dorningo. 16 The five-member special committee, chaired by Argentine Ambassador Picardo Colombo and composed of representatives from Argentina, Brazil, Colombia, Guatemala, and Panama, left for Santo Domingo the next day aboard a U.S. aircraft. 17 Once in place, the committee played an important role in negotiations and in reporting local conditions to the OAS Council and the ministers. Secretary General Mora arrived in Santo Domingo just before the committee, and his appearance and individual efforts to promote peace in Santo Domingo marked the first time that an OAS leader had personally participated in such a mission. 18 His intercession in the conflict reflected the degree of concern that the Latin nations felt about both the violence of the civil war and the unilateral American intervention. Although the United States was not a formal member of the committee, its influence was seen in the committee's reports and in their positive position on the establishment of an inter-American force. Thus, the formation of the special committee laid the foundation for the Organization of American States to take action on the Dominican situation.

\section{Debates on an Inter-American Force}

Before the 6 May foreign ministers' vote on an inter-American military force, the OAS members displayed an unexpected level of reluctance toward the American proposal for a multinational force. Many Latin American nations 
suspected President Johnson's motives and feared giving legitimacy to an American return to interventionism. Considerations for public opinion at home and an awareness that any action they might take would be interpreted as one Latin acting against another on behalf of the United States forced many political leaders to temper support for an OAS-sponsored force. 19

President Johnson used this period to strengthen his case concerning Communist domination of the rebel forces in Santo Dorningo and to stress the importance that Latin American contributions could make to ending the hostilities. The United States tried to reduce the damage that its unilateral actions had already caused by stressing neutrality in dealing with the two factions. While obvious in intent, the plan seemed to have some success. Opposition within the Organization of American States began to decline as time passed and as more information became available from the cornmissions and committees that visited Santo Domingo. 20

On Monday, 3 May, the OAS Council received two reports from its special missions that had been in Santo Domingo. These reports concluded that conditions had deteriorated to the point where intervention had become necessary and detailed the conditions they found on their arrival: "We were deeply moved and saddened... [there is] an evident lack of security and of authorities having effective control ... the atmosphere was one of tragedy, mourning, and real human anguish." As if to heighten the special cornmittee's apprehensions, Colonel Caamano advised its inembers to use an ambulance to travel inside Santo Dorningo since he could not guarantee that the rebels would not fire on any other type of transport. 21 Both reports reluctantly called for the introduction of Latin American troops so that U.S. troops could be reduced or totally withdrawn. This was the opportunity Johnson had been waiting for. The call for Latin troops by the OAS cornmittees lent credence to his desire to involve other regional nations. At the same time, the recommendations provided the Latin governments with the means to react under the premise of reducing U.S. involvernent in the region.

Supported by the reports' recommendations, Ambassador Bunker formally called for a vote on the resolution to establish an inter-American force. 22 This stand had not been unforeseen and was, in fact, the culmination of a great deal of American pressure on the committees. The inter-American force would be 
used to establish an atmosphere where negotiation and conciliation could prosper, with neither faction feeling millitarily threatened by the other. "The United States forces that are there have been employed to help carry out the resolutions of the Organization of American States," Bunker said. "We are anxious ... to create a multinational force. We would hope that member countries would supply forces so that we might withdraw some of our own. We would hope that all forces could be withdrawn at the earliest possible moment." 23

The 6 May resolution, sponsored jointly by Argentina, Bolivia, Brazil, Colombia, Costa Rica, and Venezuela, called for the formation of a unified inter-American force under the control of the OAS Meeting of Foreign Ministers. 24 Its mission would be to maintain the security of the inhabitants, protect human rights, and establish an atmosphere for reconciliation and the resumption of democratic institutions. Secretary General Mora would request volunteer forces reinaining under the control of their national services but acting under the operational command of the OAS force commander. The force cornmander in turn would receive guidance and instructions from the ministers.25 The Meeting of Foreign Ministers would remain in session to provide this guidance and would keep the United Nations informed of its actions. The ministers would be impartial and would be empowered to withdraw the forces. The resolution also provided the United States a legitimate umbrella under which to operate until OAS forces could be found and provided President Johnson with multilateral support for his anti-Communist policies. Finally, the resolution gave the Organization of American States an opportunity to demonstrate its ability to handle a violent situation through coordinated joint action. (Chart 2)

The positive vote that followed the Inter-American Peace Force debate was a relief for Ambassador Bunker, the president, and all American ambassadors in Latin America. Temporarily at least, it relaxed the pressure to get a positive vote on the inter-American force from their host nations. The charter required a two-thirds majority for resolutions calling for armed actions, and the final vote on the resolution was fifteen to five: Mexico, Uruguay, Chile, Ecuador, and Peru voted against the resolution. Venezuela, torn between a long-standing contempt for communism and strong revulsion for American 
Chart 2 - Command Relationships, Inter-American Peace Force

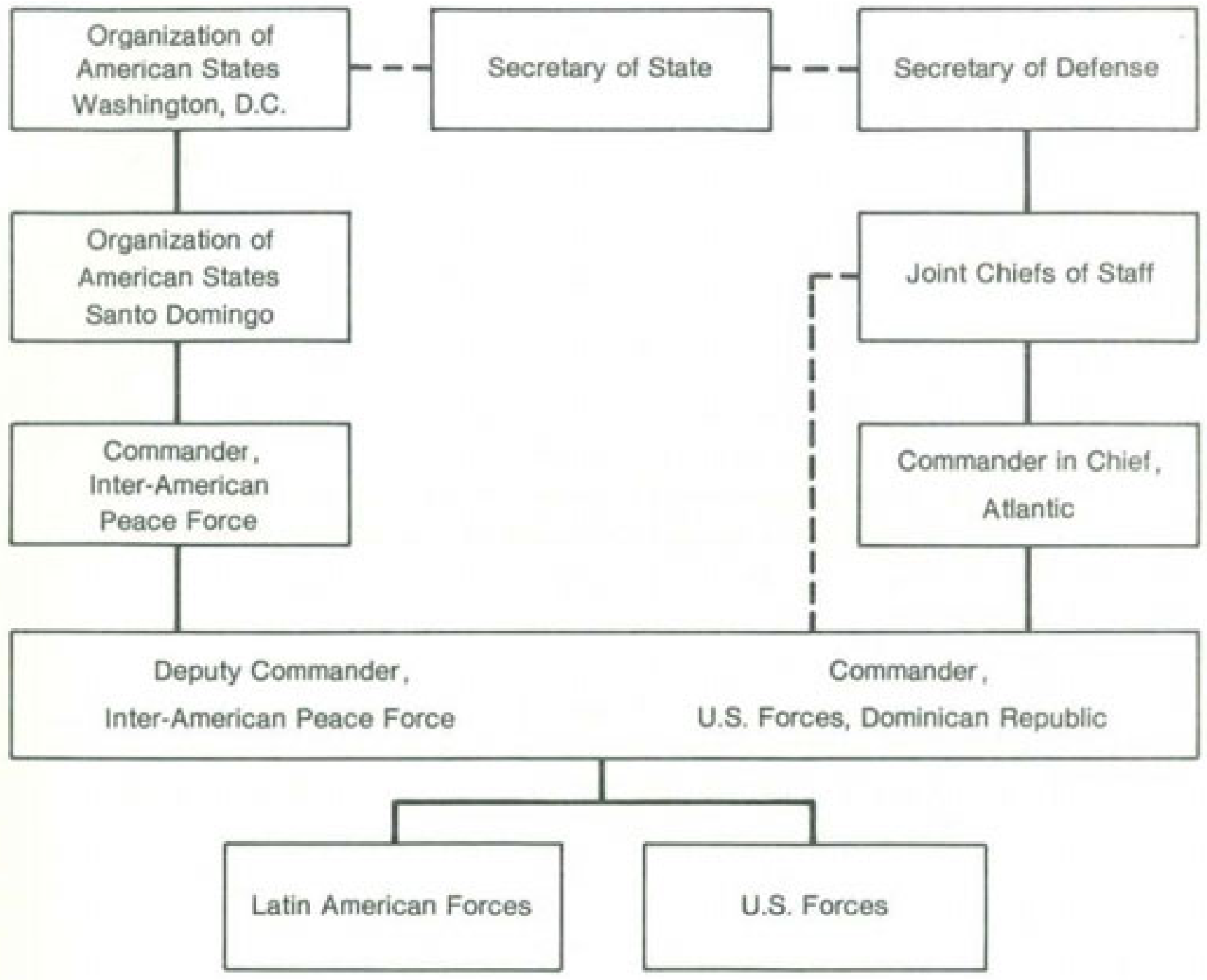

\footnotetext{
- Direct Operational Control

- Coordination
}

Source: Department of the Army, Challenge: A Report by the Chief of Statt (Washington, D.C.: Department of the Army. Jul 64 - Apr 68), p. 353. 
interventionism, abstained but agreed to abide by the majority's decision. 26

\section{Composition of the Force}

Now began the search to find soldiers for the new force. Initially, Secretaries Rusk and McNamara anticipated military participation from Venezuela, Brazil, Argentina, Costa Rica, and several other nations in Central America. Events within Latin America soon took unexpected turns, however, and large anti-American demonstrations occurred in many capitals. The vast majority of Latin newspapers reflected these sentiments, and anti-American articles and editorials outnumbered pro-American ten to one. 27 Although supporting Johnson's objectives, Venezuelan President Betancourt felt that unilateral actions had forced Latin America into a fait accompli by not seeking OAS support first. 28 Argentine and Colombian military leaders favored sending troops but were blocked by domestic considerations as well as Argentina's distrust over the OAS offer to have Brazil name the military commander. Panama and Bolivia opposed U.S. military actions but voted in favor of the resolution and supplied humanitarian aid. Paraguay agreed to send troops only if everyone else did. And, not too surprisingly, Haiti was not asked to contribute. 29

On 12 May, Honduras became the first nation formally to offer troops for the inter-American force. Brazil, Nicaragua, Costa Rica, and El Salvador soon followed. 30 On 22 May Mora asked Brazil to name the commander and the United States to name his deputy. 31 The first Latin American troops, Honduran infantry, arrived in the Dominican Republic on 14 May and began operations with the newly named Inter-American Peace Force nine days later. National contributions to the non-U.S. portion of the force were: Brazil, 1,130; Honduras, 250; Nicaragua, 160; Paraguay, 184; EI Salvador, 3 staff officers; and Costa Rica, 20 policemen (Costa Rica did not have a standing military force). Ambassador Bunker's original offer to place all 21,500 U.S. troops already there under Inter-American Peace Force command was later amended to a 6,243-man permanent contingent. 32

Many nations that opposed the force nevertheless responded to a Meeting of Foreign Ministers' resolution of 3 May calling for humanitarian aid. ${ }^{33}$ The 
United States, Mexico, Venezuela, Argentina, Brazil, Bolivia, Peru, Colombia, Panama, and Puerto Rico contributed food, medicine, and clothing. The OAS Relief Coordination Center was established in Santo Domingo on 8 May and coordinated relief operations throughout the life of the peace force. It worked in conjunction with Dominican public health authorities, the Pan American Sanitary Bureau, the U.S. Agency for International Development, Caritas, CARE, the International and Dominican Red Cross, and Church World Services. By the end of August, OAS members had contributed 62.6 million pounds of foodstuffs for the relief effort. ${ }^{34}$ In addition to food, doctors and nurses from many nations began to arrive on the island as early as 6 May. The willingness these nations showed to provide such assistance demonstrated their desire to help, but through means other than military force. Considering the domestic political situations in many of these nations, humanitarian aid was the only realistic form of assistance they could offer.

\section{The Resolution Becomes Reality}

General Palmer assumed temporary command of the peace force until Brazilian General Hugo Panasco Alvim arrived on Friday, 28 May. Kept informed of events at the Organization of American States by the Joint Chiefs of Staff, General Wheeler directed Palmer, who opposed placing the force under non-U.S. command, to protect U.S. influence as much as possible. Thus, Palmer formed a skeleton headquarters even before the force was activated officially. The headquarters was established in the Hotel Jaragua on the coast southeast of the American embassy, and officers already assigned to XVIII Airborne Corps formed a cadre staff. By forming the cadre staff before the Brazilian commander arrived, Palmer assured that adequate U.S. influence would continue in the new organization. General Palmer had first expressed fear of losing autonomous action to the secretary of defense on 9 May, and Palmer and Admiral Moorer reiterated that fear on the 27 th in message traffic with General Wheeler. Wheeler responded that the only viable option for the InterAmerican Peace Force was to have a Latin commander who would share responsibility with Palmer as his deputy. 
The United States, by supplying the vast majority of inanpower and almost all logistics, would be able to influence the actions of the force without cornmanding it. An intra-regional military peace-keeping force under OAS control was far more palatable in Latin America than was one under U.S. control; at the same time, the regional force would tend to seek the same goals as the United States -- ending the strife and preventing a Communist takeover. Any overt atternpt to inaintain American autonomy or independence of action while part of the force was politically taboo. General Wheeler clearly stated his position, and reinforced the primacy of political considerations in the intervention, when he told General Palmer and Admiral Moorer, "We devised the IAF [inter-American force] concept for the purpose of giving an international cover to American military involvement in the Dominican Republic and to legitimatize our activities in world opinion by identifying them with the OAS." 35

Even before these rudimentary steps were taken, the first elements of the Inter-American Peace Force began to arrive in the Dominican Republic. The Honduran contingent of some 250 officers and enlisted men deployed to San Isidro aboard U.S. aircraft on 14 May. Their arrival highlighted a problem that caused consternation among U.S. planners and logisticians. To entice support for the Inter-American Peace Force, the United States offered to provide all supplies and logistics to any participating contingents. Thus, except for the Brazilian contingent, Latin soldiers arrived with their weapons but little else. 36 Faced with having to feed and outfit the arrivals from stocks meant for only American troops, General Palmer suggested to the joint chiefs that further Latin troop deployments be delayed until additional supplies became available or until the Latin governments made their own arrangements for supplies. His suggestions were not accepted; making the peace-keeping force multinational as soon as possible became President Johnson's highest priority once the military stalemate had been achieved between the two Dominican factions. To lessen Palmer's immediate burden, however, Secretary of Defense McNamara directed that additional food, clothing, tentage, and non-U.S. standard ammunition be sent directly to the Dominican Republic from storage depots in the continental United States. The United States continued to feed, house, and supply the non-Brazilian forces for the duration. 
Nicaraguan and Costa Rican troops arrived in Santo Domingo on 15 May. The $82 \mathrm{~d}$ Airborne Division's assistant division commander and G-3 briefed arriving contingent commanders on the military situation and on how their forces would be supported and employed. Lead elements of the Brazilian infantry battalion arrived on 22 May, and the Brazilian contingent that included 1,130 men and almost .75 million pounds of equipment arrived at San Isidro airfield by the 28 th. 37 When Paraguayan and EI Salvadoran contingents arrived a month later, the total Latin American strength was brought to 1,763 officers and enlisted men. 38

On the afternoon of Sunday, 23 May, representatives from five nations met in the Hotel Embajador to sign a document that produced a singular experiment in cooperation for the Organization of American States and changed the modus operandi employed by the United States to influence events in Latin America. When the last national contingent commander put his name to the Act Creating the Inter-American Peace Force, a new organization and concept for collective action was born. This was the first time sovereign states within the Americas banded together to form a regional multinational military force. 39 The formation of this force did not prove easy. Not only was it an experiment in coalition military operations, but the very conception of such a force required the OAS members to overcorne suspicions of the United States and of Latin neighbors as well.

The signing ceremony in Santo Domingo that May afternoon did more than give the Inter-American Peace Force its legal birthright. It ended weeks of diplomatic maneuvering between the United States -- seeking regional and international approval through multinationalization - and Latin nations who tended not to see issues and solutions from the same perspective as did the "giant to the north." After he signed the document, OAS Secretary General Mora announced: "[The Inter-American Peace Force would provide] for the promotion of the peace and the tranquility, under conditions that will permit the Dorninican people to establish a democratic civil government, to hold elections, [and] close the wounds and bitterness from the civil war and follow the road of help and reconstruction. ${ }^{n 40}$

General Alvim assumed command of the unified force on $29 \mathrm{May}$, in a ceremony at the Hotel Jaragua, and immediately set about formalizing staff 
and order of battle. 41 The headquarters, as established by General Palmer, had six major staff sections bearing " $\mathrm{C}$ " designations and was similar in function to standard U.S. organizational staffs. General Alvim designated American officers as deputy commander, deputy chief of staff, supply and logistic officer, provost marshal, information officer, and deputies in all other sections. The headquarters was staffed with 156 men divided equally between U.S. and Latin officers, although the vast majority of enlisted men (42) were Americans. ${ }^{42}$ Hampered by language barriers and, at least in U.S. eyes, by a generally lethargic approach to staff work, they functioned reasonably well throughout the operation. The Army reduced the language barrier by identifying and deploying Spanish-speaking officers and enlisted men to the headquarters. Although 1,100 U.S. officers were assigned within Latin America at the outbreak of the civil war (in military assistance advisory groups, other military assistance groups, and attache assignments), this pool of talent went largely untouched; only 4 of the 47 chosen for the U.S. part of the peace force staff had Latin experience. ${ }^{43}$ Differences about roles and responsibilities were never reconciled fully, although they were generally overcome by U.S. officers "picking up the slack" and through similar theories of military staff organization as taught by U.S. military schools and the School of the Americas. Staff functioning was also improved significantly by a sense of camaraderie and understanding that developed between the officers themselves.

Another American concern dealt with regulations establishing command relationships within the peace force. The State Department sent General Palmer a draft set of regulations on 28 May. "Regulations for the OAS InterAmerican Force," based on a proposal that General Palmer and Ambassador Bennett submitted to Washington on 9 May, formalized the organization of the headquarters and made the deputy commander the "alter ego of the commander," empowered to act with the voice of the commander and without reservation in his absence. 44

Combat units were organized into two forces -- U.S. and Latin American. Because of their relatively modest number, initially all Latin contingents were placed in a Latin American brigade and on 4 June came under the command of Brazilian Col. C. de Meira Matlos. With the arrival of the Nicaraguan and Costa Rican units, the brigade was subdivided into the Fraternity Battalion, 
composed of the Brazilian marine company and all non-Brazilian troops, and the Brazilian Battalion, made up entirely of Brazilian infantry. 45 The American contingent (composed of the 1st Brigade, 82d Airborne Division; 16th General Supply Group; 7th Special Forces; and Air Force elements) remained under General Palmer. This procedure satisfied Palmer, Moorer, and the joint chiefs' concerns about placing U.S. troops under the direct control of a foreign cornmander. In theory, U.S. forces would be under the operational control of the Inter-American Peace Force and, through it, the Organization of American States. In reality, they remained under the direct control of General Palmer, whom, before he left for the island, General Wheeler had told that the president expected to follow directives from his national chain of cornmand should differences between U.S. and OAS objectives arise. 46 (Chart 3)

\section{Operations in Santo Domingo}

By late May the fluid military situation in Santo Domingo was essentially stabilized, and the United States began to withdraw combat troops. Earlier that month, even as U.S. forces were arriving on the island, Secretaries Rusk and McNamara discussed this process as a means to develop support for an OAS peace force. Army units not involved in the security of the line of communication, International Security Zone, or San Isidro Airfield, as well as the vast majority of division artillery, began to return to Fort Bragg on 29 May. The Marines, the first in and the most visible symbol of the United States, were the first to redeploy and by early July had all departed. By 24 June, onshore U.S. strength had been reduced from its 17 May peak of 21,900 to some $12,400.47$ By Christmas Day, only those elements specifically dedicated to the Inter-American Peace Force remained on the island. 48

These troop reductions reflected more than relative peace and stability in Santo Domingo. Primarily, the withdrawals demonstrated to the members of the Organization of American States that the United States would act in good faith to reduce its military presence as Latin troops joined the force. Second, the reductions showed American confidence in the ability of the Latin troops to maintain the peace, backed as they were by an $82 \mathrm{~d}$ Airborne Division brigade. The latter proved important in obtaining contributions for the peace force 
Chart 3 - Organization, Inter-American Peace Force

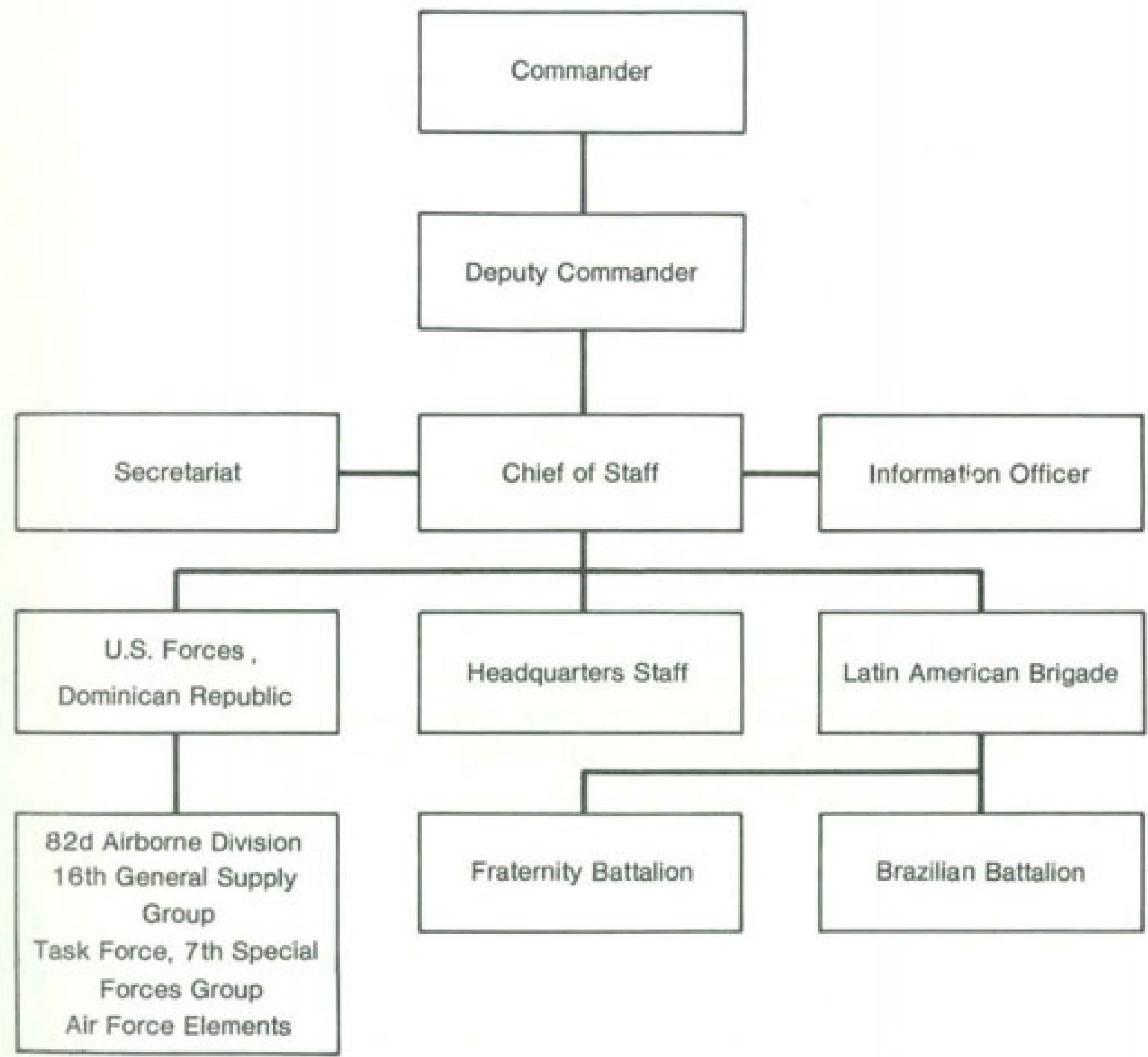

Source; Organization of American States, Fuerza Interamericana De Paz (Washington, D.C: Pan American Union, 1066), P.15. 
as well as supporting those governments that had made early offers of troops. Finally, the reductions were aimed at calming discontent and debate over the president's policies in Congress and in the press. In retrospect, the reductions influenced public opinion more in Latin America than in Washington.

Even before assuming an official role, Latin American units were placed in the relatively quiet security zone as members of joint military police patrols and observation teams to monitor the cease-fire. These teams, which began operations on 24 May, roamed the Loyalist-held areas of Santo Domingo and reported to General Palmer. Each three-man military police patrol was composed of an American, a Honduran, and a Costa Rican soldier. Two days after they began operation, the patrols were augmented by all-Latin observation teams who reported cease-fire violations and civil troubles to the peace force staff. Beginning on 29 May and continuing through early June, Brazilian units relieved U.S. troops along the International Security Zone, secured the presidential palace, and established security checkpoints in the vicinity. At the same time, units from the all-Latin Fraternity Battalion began to occupy positions on the security zone and line of communication perimeters adjacent to rebel territory. 49

In June, Colonel Caamano's rebel forces tested the resolve of the new coalition. On the 6 th they suspended negotiations and fired at troops along the line of communication. U.S. and Latin troops returned fire in a demonstration of their will to hold the corridor open and inviolate. After a brief but violent exchange, the rebels withdrew into Ciudad Nuevo. Then, one week later on 15 June, the rebels launched a second and final attempt to expand out of their stronghold. Commencing at 0750, they attacked American outposts along the line of communication with sporadic but coordinated small arms fire. By 0915 they were directing continuous fire against U.S. forces, and at noon they assaulted Brazilian positions. 50 Despite the coordinated attack involving mortars, bazookas, and several tanks, the rebels lost a 56-square-block area to 82d Airborne Division units which had received OAS permission to advance. During the battle, twenty-four American and five Brazilian soldiers were wounded and sixty-seven rebels were killed. 51

The June offensive fully initiated the Latin troops to battle. Although Brazilians did not leave their defensive positions, they returned fire with great 
bravado, expending far more ammunition than did their American comrades. Failure to split the Brazilians from the American troops and the loss of territory so demoralized the rebels that they returned to the negotiating table.

Three days later, on 18 June, the OAS ad hoc committee (created by a Meeting of Foreign Ministers resolution on the $2 \mathrm{~d}$ ) achieved a major diplomatic breakthrough and the first concrete step toward a final political solution. The committee was composed of three members: Ilmar Penna Marinko of Brazil, Ramon de Clairmont Duena of El Salvador, and Ellsworth Bunker of the United

States. After 101 separate meetings with the Constitutionalists and Loyalists (48 with Caamano and 53 with Imbert), an agreement established a provisional government that would rule until elections could be held within six to nine months.52 The population was to be disarmed and the Inter-American Peace Force and OAS Human Rights Commission were to remain in Santo Domingo until the promised elections took place. At noon on 18 June, U.S. helicopters dropped 70,000 copies of the agreement in Santo Domingo and the adjacent countryside in an attempt to show the population that peace was at hand and to calm feelings from the recent rebel offensive. 53

The peace force had taken military control of the situation in Santo Domingo from the rebels and given it to the OAS negotiators. Following the fighting in mid-June, it became obvious that the force was there to stay and that it was willing to carry out its mission of peace-keeping in support of a negotiated settlement. In later years, General Palmer credited the resolve and determination of the inter-American force during June 1965 with speeding the situation toward resolution. The next task for the Organization of American States was to seek an acceptable caretaker government until proper elections could be held.

\section{The Provisional Government and the Peace Force}

The OAS ad hoc committee agreement, signed following the thwarted rebel offensive of 15 June by Colonel Caamano and General Imbert, opened a month of negotiations to find an acceptable leader for a provisional government. On 10 July both factions approved Hector Garcia-Godoy with the proviso that his government use an interim constitution rather than that of 1962 
or 1963. Ambassador Bennett suggested Garcia-Godoy after Caamano rejected the original U.S. nominee, Rafael Bonnelly, as being too closely linked with the Loyalist military. After another six weeks of intensive negotiations with Imbert, and with Ambassador Bennett relaying President Johnson's threat to sever U.S. economic aid to him unless a new provisional government was formed, the OAS-proposed Acts of Reconciliation and Institutional Act was ratified on 31 August. 54 The acts proposed to restore peace to the island, to promote economic recovery, to establish democratic institutions, and to assure that Dominican citizens could live under a systern of freedom and justice rather than the anarchy and chaos that had existed since 24 April.55 Colonel Caamano's signature on the document officially ended the civil war and led to the dissolution of both the Constitutionalist and national reconstruction governments, making way for the new provisional government. Among the Constitutionalist signatories to the acts were Antonio Silvestre Guzman and Salvador Jorge Blanco, both of whom later became presidents of the republic.

Garcia-Godoy was sworn into office on Sunday, 3 Septernber, on the steps of the national palace and was extended U.S. diplomatic recognition on the 4 th. He pledged impartiality, a removal of the military from politics, and an end to corruption in government. 56 Supported by $\$ 20$ million in U.S. aid, food, and medicine, Garcia-Godoy began to calm the situation. One of his first official acts was to order the reintegration of General Wessin y Wessin's autonomous Armed Forces Training Center into the regular Dominican Army. Not surprisingly, the powerful general was less than enthusiastic about this plan, and he challenged it directly on 9 September. Under the guise of a farewell address to his troops, he massed his tanks and began a slow road march toward Santo Domingo. Suspecting a coup, Garcia-Godoy requested assistance from Generals Alvim and Palmer, who ordered an American battalion to prevent the heavily armed force from entering the city. U.S. troops blocked the highway leading to the Duarte Bridge and brought the advancing armored column and Wessin $y$ Wessin's hopes of retaining his power to a halt. 57

As an aftermath to this episode, General Wessin y Wessin was retired and put aboard a commercial aircraft to Florida, where he became the Dominican Republic's consul general.58 Realizing that the United States had backed his expulsion, Wessin y Wessin publicly announced that he had been "forced to leave 
at the point of an American bayonet." Actually, the U.S. officers who escorted him to the plane were armed with pistols. 59

The formation of the provisional government shifted the role of the InterAmerican Peace Force from neutrality to support of the new government. 60 The force gave Garcia-Godoy the time he needed to establish his government, reduce tensions, and hold elections. Generals Alvim and Palmer prevented a second military coup attempt in late September, using their new directive to support the provisional government. Hearing that the military was about to issue a decree which would in effect refuse to recognize Garcia-Godoy's authority, Alvim and Palmer met secretly with the military leaders and convinced them that the Inter-American Peace Force would act to preserve the government. The proclamation was never issued.

Besides military support, the inter-American force (actually the U.S. contingent) provided the provisional government with tangible material and training support. Consumables such as food, petroleum products, medicine, and building materials went to the Dominican armed forces, the national police, and the former Constitutionalists at the 27 th of February Camp. In addition, iterns such as light vehicles, tentage, uniforms, and armored vests went primarily to the national police. To round out the support package, the U.S. $2 \mathrm{~d}$ Battalion, 504 th Infantry, provided nearly 6,000 man-hours of counterguerrilla training to the Dominican Mella Battalion at Camp Mella. This three-week course included instruction and practical field exercises concentrating on camouflage, demolitions, and intelligence gathering and processing. American forces also provided routine transportation, publication, and communication support on demand to the Garcia-Godoy government. Excluding this last category of support, U.S. Forces, Dominican Republic, directly contributed over $\$ .2$ million in supplies and equipment. 61

With the peace force firmly behind him, Garcia-Godoy continued to make changes. He reorganized the national police, so long a point of controversy, under the Ministry of the Interior and announced plans to disarm Ciudad Nuevo and move the rebel forces out of the city. Realizing that his own forces were unprepared for such an undertaking, Garcia-Godoy requested assistance from General Palmer and the Inter-American Peace Force. On 25 October the 1st Brigade of the $82 \mathrm{~d}$ Airborne Division, augmented with two infantry battalions 
from 2d Brigade, began to sweep south across Ciudad Nuevo from positions along the line of communication. Simultaneously, the Latin American Brigade took up blocking positions to the west, effectually sealing Ciudad Nuevo between inter-American forces and the Ozama River. The operation proceeded without serious incident and ended with peace-keeping troops escorting Colonel Caamano and his remaining supporters to the 27 th of February Camp, located on the eastern bank of the Ozama. On 1 November the 1st Brigade withdrew from Ciudad Nuevo, leaving one company of the 1st Battalion, 504th Infantry, occupying the city power plant and the Duarte Bridge. 62 .

With the core of Constitutionalist resistance removed from Santo Dorningo, daily life in the city began to return to normal under the care of the provisional government and the watchful eyes of the peace force. By the second week of November, banks and newspapers resumed operation and the port of Santo Domingo reopened. The reorganized national police received training and equipment from U.S. forces and gradually exerted control over the city, although occasional outbreaks of lawlessness continued. Within the provisional government, discussions turned toward a timetable for merging the autonomous national police with the army. ${ }^{63}$ Santo Domingo was still far from peaceful, but it was finally beginning to recover and return to normal.

Throughout the summer of 1965, inter-American troops maintained ten security checkpoints to control access and stop the flow of arms and munitions into Ciudad Nuevo. Their effectiveness became visible in early July with the appearance of the first anti-Brazilian slogans alongside the mandatory "Yankee go horne" graffiti.

Before the scheduled elections, President Garcia-Godoy called upon InterAmerican Peace Force troops to stop several violent clashes between former Constitutionalists and Loyalist military in Santiago and Barahona, both located to the northwest of Santo Domingo. (Map 9) During the night of 21-22 November, riots broke out in these two cities when former Constitutionalists seized local radio stations. Shortly after taking control, the rebels announced that they had established a new Dominican government. The latest coup was to be short lived, however, as President Garcia-Godoy dispatched Dominican troops to the cities and requested inter-American support. Part of the Ready Reaction Force, Company C, 2d Battalion, 508th Infantry, went immediately to 


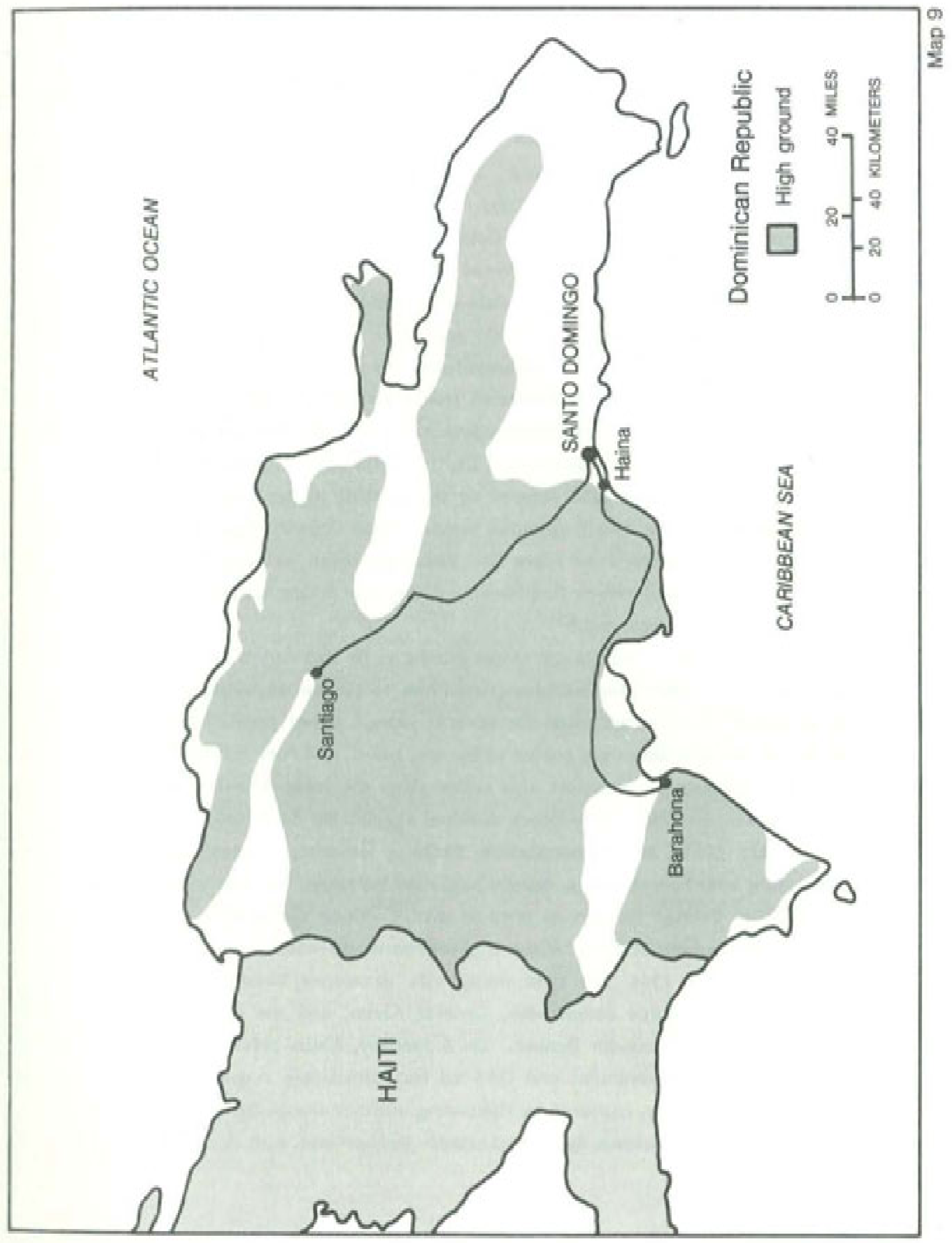


the area. Although the company did not participate in the actual fighting to regain government control, its presence was credited with helping Dominican forces put down the new uprising. 64

A second, and more serious, incident occurred on 19 December in Santiago, when police and military troops attacked a large group of Constitutionalists. That morning Colonel Caamano and approximately 150 armed Constitutionalist soldiers traveled by motorcade from Santo Domingo to Santiago to celebrate Mass for a slain rebel lieutenant. At 0900 , following Mass, 300 Loyalist troops and national policemen set upon the group as they proceeded to the Hotel Matum for breakfast. The ensuing gun battle raged for five hours until a company of American troops arrived by plane and helicopter from San Isidro Airfield. The paratroopers maneuvered themselves between the factions and allowed their commander, Lt. Col. John Costa, to negotiate for the release of fifteen Americans trapped by the fighting in the hotel and for the disengagement of the two Dominican forces. Soon Colonel Caamano and his supporters were allowed to leave for Santo Dorningo, but not before four Constitutionalists and eleven Dominican military and police were killed and an additional eighteen wounded. 65

The incident at the Matum Hotel proved to be Caamano's swan song. In late January of 1966 Garcia-Godoy posted him to London as military attache; he remained there in seclusion for several years. Other prominent military leaders of the rebellion were posted to Europe, Israel, and Puerto Rico. 68

The provisional president also called upon the inter-American force to quell sporadic outbreaks of violence directed against the Santo Domingo police in February 1966. In one particularly barbaric incident, a crowd set upon a policeman, beat him severely, doused him with kerosene, set him aflarne, and dragged him through the streets until he died.67 Once again, the peace force acted on the request of the provisional government and restored order.

In January 1966 the first major rift developed between the InterAmerican Peace Force commander, General Alvim, and the U.S. diplomatic mission led by Ambassador Bunker. On 6 January, Alvim refused to act on a joint provisional government and OAS ad hoc committee request to occupy Radio Santo Domingo, captured by right-wing military troops during an aborted coup attempt the previous day. Ambassador Bunker met with Alvim and told 
him that he would instruct General Palmer to recapture the radio station with American troops if Alvim refused to issue the order. Faced with this ultimatum, Alvim gave in; acting under his orders, U.S. paratroopers seized Radio Santo Domingo the next day. In a face-saving move, Brazilian President Castelo Blanco agreed to remove General Alvim if the United States also replaced General Palmer. Later that month, Brig. Gen. Alvaro de Silva Braga and Brig. Gen. Robert R. Linvill took command.68 The replacement of a general and a lieutenant general with two brigadier generals further signified the diminishing military role of both the United States and the Organization of American States in restoring normality to the Dominican Republic.

\section{The Election of June 1966}

Dominicans approached the scheduled June election with mixed feelings and expectations. Since independence, the nation had had twenty-seven constitutions and some thirty-two elections, of which perhaps only four could be considered reasonably free and honest. 69 Often losers had prevented winners from taking office. In this instance, the U.S. State Department and the InterAmerican Peace Force made it clear that the new elections would be free, honest, and binding. They established three sets of observers to monitor elections throughout the island: the provisional government's Central Election Commission, a 41-member OAS observation team (representing eighteen member nations), and an unofficial but State Department-sponsored U.S. team of nine observers under Socialist Norman Thomas. 70 All three groups agreed that the elections had indeed been free from obstruction or pressure and, despite minor irregularities in registration procedures, had been conducted honestly and in good faith.

Eleven of twelve recognized political parties participated in the June election, but the race was between three former Dominican presidents -Balaguer, Bonnelly, and Bosch. Balaguer won the election with 57.7 percent of the 1.3 million ballots cast, defeating his closest rival, Bosch, by 8.3 percent. 71 Bonnelly, representing the right wing, finished a poor third with less than 3 percent of the vote. Why had Bosch, the symbol and voice of the Constitutionalist cause, lost? General Palmer provided the best answer. He 
attributed Bosch's loss to flaws in his character; that is, Bosch lacked machismo and appeared cowardly by remaining in exile for so long before and during the civil war. 72

Exactly one year and two months after the start of the civil war, and acting upon a request from Provisional President Garcia-Godoy, the OAS Tenth Meeting of Foreign Ministers passed a resolution on 24 June 1966 calling for the withdrawal of the peace force to begin before 1 July and be completed within ninety days. 73 On 28 June the ministers issued orders to General de Silva Braga directing the redeployment of the 8,000 troops from the republic. 74 The withdrawal began with the remaining battery of the U.S. Ist Battalion, 320th Artillery, on 28 June and continued throughout the summer. The Costa Rican detachment left in July; the Brazilian marines and the infantry from Honduras, Nicaragua, Paraguay, and Panama left in August; and by 21 September the last of the U.S. and Latin troops were gone. General de Silva Braga boarded a Brazilian transport plane on 21 September and brought the mission to a close. ${ }^{77}$

The last soldier to leave Dominican soil was General Linvill, and on 27 September 1966 the Organization of American States officially deactivated the Inter-American Peace Force. 76 The operation cost 237 casualties and a financial expenditure of $\$ 311$ million by the United States for both humanitarian aid and military-related costs. 77 (Table 1) 


\section{Table 1 - Inter-American Peace Force Casualties:}

April 1965 - September 1966

\begin{tabular}{c|c|c|c|c}
\hline & Killed in Action & Wounded in Action & Non-Combat Dead & Total \\
\hline U.S. & 27 & 172 & 20 & 219 \\
Latin & 0 & 17 & 1 & 18 \\
\hline Total & 27 & 189 & 21 & 237
\end{tabular}

Source: Washington Center of Foreign Poliscal Pesearch, National Support of International Peacekeeping and Peace Observation Operations (Washington, D.C.: Johns Hopkins University, Feb 7O), pp. 289-313. 


\section{Notes - Chapter IV}

1. Gabriel Marcella, Dimensions of U.S.-Latin American Military Relations, ACN 78062 (Carlisie Barracks, Pa.: U.S. Army War College, 5 Sep 78), p. 2.

2. Jack Child, "Post-War U.S. Strategy Planning for Latin American (1945-76): from 'Rainbow' to 'IDAD'," Rpt presented to Eleventh Military History Symposium, U.S. Air Force Academy, Colorado Springs, Colo., Oct 84.

3. M. Margaret Ball, The OAS in Transition (Durham, N.C.: Duke University Press, 1966), p. 450.

4. John Carey, ed., The Dominican Republic Crisis 1965 (Dobbs Ferry, N.Y.: Oceana Publications, 1967), p. 10; Paul Hofman, "Cuba Assails Marine Landings; Other Latins Express Concern," New York Times, 30 Apr 66.

5. Memo of Conversation, Rusk and Betancourt, 3 May 65, National Security Council (NSC) History, Dominican Republic Intervention, LBJ Library, Austin, Tex.

6. Washington Center of Foreign Political Research, National Support of International Peacekeeping and Peace Observation Operations (Washington, D.C.: Johns Hopkins University, Feb 70), p. 262.

7. Center for Strategic Studies, Dorninican Action -- 1965: Intervention or Cooperation, Special Rpt ser. no. 2 (Washington, D.C.: Georgetown University, Jul 66), p. 44.

8. Yale H. Ferguson, "The Dominican Intervention of 1965: Recent Interpretations," International Organization 27 (Auturnn 73): 534.

9. Washington Center, National Support, p. 264.

10. Cese de Fuego Firmado el 30 de ABRIL DE 1965 (Ceasefire Signed on 30 April 1965), personal papers of Amb. W. Tapley Bennett, Jr., file 9, box 4416 83D358, U.S. Department of State historical files, Washington, D.C.; Resolution, Council of the OAS, $30 \mathrm{Apr} 65$, "Cessation of Hostilities and the Establishment of an International Neutrality Zone," in The OAS Chronicle 1 (Washington, D.C.: Pan American Union, Aug 65): 20; Center for Strategic Studies, Dominican Action, Pp. 44-45.

11. Melvin $\mathrm{H}$. Johnsrud, "In the Dominican Crisis, Was Peace Victorious?" student thesis (Ft. Leavenworth, Kan.: U.S. Army Command and General Staff College, 1968), p. 11; John W. Finney, "Washington Declares Its Right to Protect American Lives," New York Times, 30 Apr 66; Center for Strategic Studies, Dorninican Action, p. 47. 
12. U.S. Department of State, "The Dominican Crisis: The Hemisphere Acts," Inter-American ser. 92 (Washington, D.C.:Government Printing Office, Oct 65).

13. Center for Strategic Studies, Dominican Action, p. 49.

14. U.S. Congress, Senate, Committee on Foreign Relations, "Background Information Relating to the Dominican Republic," 89th Cong., 1st sess. (Washington, D.C.: Government Printing Office, Jul 65), p. 21.

15. Richard W. Mansbach, ed., Dominican Crisis 1965 (New York: Facts on File, 1971), p. 52.

16. Resolution, OAS Tenth Meeting of Consultation of Ministers of Foreign Affairs (MFM), "Special Committee to Seek the Re-Establishment of Peace and Normal Conditions in the Dominican Republic," doc. 11, rev. 2 (Washington, D.C.: Pan American Union, 1 May 65).

17. OAS Tenth MFM, "First Report of the Special Committee of the Tenth Meeting of Consultation of Ministers of Foreign Affairs," doc. 47 (Washington, D.C.: Pan American Union, 1965), p. 1; List of Assignments, U.S. State Dept, 1 May 65, NSC History; Luis Iturralde Chinel, La O.E.A. y la Revolucion Dominicana (Washington, D.C.: Union Panamericana, 1967), p. 51; Speech, Lt Gen Bruce Palmer, Jr., for AUSA Mtg, 11 Oct 66, Washington, D.C., sub: U.S. Stability Operations in the Dominican Republic, in private papers collection, Military History Institute, Carlisle Barracks, Pa.

18. Ferguson, "The Dominican Intervention of 1965," p. 535.

19. Jerome Slater, Intervention and Negotiation (New York: Harper and Row, 1970), p. 84.

20. Washington Center, National Support, p. 268.

21. 3 May 65 Memo of Conversation; OAS Tenth MFM, "First Report of Special Committee," pp. 2-3.

22. Iturralde Chinel, Revolucion Dominicana, p. 59.

23. U.S. Department of State, "The Dominican Crisis."

24. Resolution, OAS Tenth MFM, sub: Inter-American Force, doc. 39, rev. 2 (Washington, D.C.: Pan American Union, 6 May 65), Pp. 1-2; Iturralde Chinel, Revolucion Dominicana, p. 59.

25. "Security Council Authorizes U.N. Representative in Dominican Republic," U.S. State Dept Bulletin 52 (31 May 65): 869-85; Resolution, OAS Tenth MFM, 22 May 65, sub: Provisions Relating to the Inter-American Force, in The OAS Chronicle 1 (Washington, D.C.: Pan American Union, Aug 65): 1-2. 
26. Mansbach, Dominican Crisis, p. 53; Iturralde Chinel, Revolucion Dominicana, p. 60.

27. Duty Log, State Dept, 6 May 65, NSC History; U.S. Senate, "Background Information," p. 26.

29. 3 May 65 Memo of Conversation, p. 3.

29. John Child, Unequal Alliance: The Inter-American Military System, 1938-1978 (Boulder, Colo.: Westview Press, 1980), p. 173; Msg, SECSTATE to All Diplornatic Posts ARA, 091745 May 65, NSC History; Duty Log.

30. U.S. Senate, "Background Information," pp. 27-31.

31. MFM Resolution, "Inter-American Force," p. 26.

32. "Statements and Diplomatic Notes of Ambassador Ellsworth Bunker to Tenth Meeting of Consultation of Foreign Ministers of the American Republics," U.S. State Dept Bulletin 52 (7 Jun 65): 912.

33. Resolution, OAS Tenth MFM, "Urgent Appeal for Aid to the Dominican Republic," doc. 25, rev. 2 (Washington, D.C.: Pan American Union, 3 May 65).

34. Msg, Acting Director of OAS Secretariat Services in the Dominican Republic to Secretary General of the Organization, 18 Sep 65, file OEA, ser. F/II.10, doc. 270-463, at OAS Columbus Mernorial Library, Washington, D.C.; OAS Tenth MFM, "Second Report of the Special Committee of the Tenth Meeting of Ministers of Foreign Affairs," doc. 81 (Washington, D.C.: Pan American Union, 2 Jun 65), pp. 17-20; Chronology, Ad Hoc Committee, 21 May 65 , in personal papers of Amb. Ellsworth Bunker, file: Chronology, box 14383 67D291, U.S. Department of State historical files, Washington, D.C.

35. Msg, CINCLANT to JCS, 2718322 May 65, and Msg, JCS 2997 to CINCLANT and USCOMDOMREP, 27 May 65, file: CJCS 091 Dominican Republic, Historical Records Division, Joint Secretariat, Washington, D.C.

36. Honduran troops had their weapons $(M-1)$, twenty rounds of ammunition, a poncho, and a mess kit. Costa Ricans had their pistols and twelve rounds, not even a change of uniform. Eldredge R. Long, Jr., "The Dominican Crisis 1965: An Experiment in International Peace Keeping," student thesis (Newport, R.l.: U.S. Naval War College, 1967), p. 51.

37. Department of the Army, Office of the Chief of Staff, "Stability Operations Dominican Republic," pt. 2, vol. IV (Washington, D.C.: Department of the Army, 28 Jan 71), p. 1.

38. Washington Center, National Support, p. 315.

39. Department of the Army, "Stability Operations," p. 1. 
40. Iturralde Chinel, Revolucion Dominicana, p. 62.

41. In later years, General Palmer described Alvim as a competent leader who generally sought compromise rather than conflict with the United States and who worked closely with him and with the desires of the U.S. government. Oral History, Gen Bruce Palmer, Jr., Military History Institute, Carlisle Barracks, Pa., p. 184.

42. Ltr, Linvill to Bunker, 10 Jun 66, sub: IAPF Authorized and Assigned Strengths, in Bunker personal papers, file: Withdrawal of IAPF, box 14384 67D291; Department of the Army, "Stability Operations," pp. 1-2.

43. Department of the Army, "Stability Operations," p. 9.

44. U.S. Forces, Dominican Republic, "Report of Stability Operations, Dominican Republic" (Santo Domingo: HQ, USFORDOMREP, 31 Aug 65), p. 13; Msg, State 1273 to Santo Domingo, 28 May 65, file: JCS IN 81835, Historical Records Division, Joint Secretariat, washington, D.C.

45. Department of the Army, "Stability Operations," pp. 1-2.

46. Palmer oral history, p. 154.

47. The first U.S. combat troops to leave the Dominican Republic on 29 May included the 20th Chemical Detachment; 2d Battalion, 321st Artillery; 1st Battalion, 320th Artillery; and 1st Battalion, 319th Artillery. USFORDOMREP, "Report of Stability Operations," Incl 2 to ch. 4; Statement by Deputy Secretary of Defense Cyrus R. Vance before Senate Foreign Relations Committee, 14 Jul 65, p. 10; Mansbach, Dominican Crisis, p. 84.

48. Elbert E. Legg, "The U.S. Military Role in Coping with a Sudden Revolt in the Dominican Republic," student thesis (Carlisle Barracks, Pa.: U.S. Army War College, 4 Jan 68), p. 13.

49. USFORDOMREP, "Report of Stability Operations," p. 14; Department of the Army, "Stability Operations," pp.3-5.

50. Msg, AMEMBASSY Santo Domingo to SECSTATE 2422, 15 Jun 65 , 2:15 P.M., in Bennett personal papers, file 46, box 4417 83D358; Chronology, U.S. Department of State, NSC History; Palmer speech.

51. Department of the Army, "Stability Operations," p. 5; Mansbach, Dominican Crisis, p. 91; Ferguson, "The Dominican Intervention of 1965," p. 9.

52. Resolution, OAS Tenth MFM, "Ad Hoc Committee for the Restoration of Democratic Order in the Dominican Republic," doc. 118, rev. 2 (Washington, D.C.: Pan American Union, 2 Jun 65); Audrey Bracey, Resolution of the Dominican Crisis, 1965: A Study in Mediation (Washington, D.C.: Institute for the Study of Diplomacy, 1980), p. 3. 
53. Mansbach, Dominican Crisis, p. 96; Bracey, Resolution of the Dominican Crisis, p. 9.

54. OAS Tenth MFM, "Act of Dominican Reconciliation and Institutional Act," doc. 363 (Washington, D.C.: Pan American Union, 7 Sep 65), in OAS Columbus Memorial Library, file OEA, ser. F/II.10, doc. 270-463; Department of the Army, "Stability Operations," p. 6.

55. Memo of Daily Notes, Amb. Ellsworth Bunker, 21 Aug 65, in Bunker personal papers, file: Ambassador's Notes, box 14383 67D291.

56. "Inaugural Address by Dr. Hector Garcia-Godoy September 3, 1965," in Bennett personal papers, file 9, box 4416 83D 358.

57. Bracey, Resolution of the Dominican Crisis, p. 33.

58. Memo, State Dept, 4 May 65, sub: Minutes of Meeting, NSC History; Cable, Acting Director of the OAS Secretariat Services in the Dominican Republic to Secretary General of the Organization, 9 Sep 65, in OAS Columbus Memorial Library, file OEA, ser. F/II.10, doc. 270-463; Iturralde Chinel, Revolucion Dominicana, p. 132-33.

59. Palmer oral history, p. 181.

60. Palmer speech.

61. Department of the Army, XVIII Airborne Corps, "Stability Operations Report, Dominican Republic (Part III)" (Ft. Bragg, N.C.: HQ, XVIII Airborne Corps, 1 Oct 66), p. 1-1; Memo, Palmer to Bunker, 27 Nov 65, sub: Support for the Provisional Government, in Bunker personal papers, file: Provisional Government, Political Matters, box 14383 67D291.

62. XVIII Airborne Corps, "Stability Operations Report," p. 1-1.

63. Draft Rpt, OAS Ad Hoc Committee to OAS, 12 Nov 65, sub: Report of the Ad Hoc Committee to the Tenth Meeting of Consultation of Ministers of Foreign Affairs, in Bunker personal papers, file: OAS/10th MFM, box 14384 67D291; Merno of Daily Notes, Amb. Ellsworth Bunker, 10 Nov 65, in Bunker personal papers, file: Ambassador's Notes, box $1438367 \mathrm{D} 291$.

64. XVIII Airborne Corps, "Stability Operations Report," p. III-1.

65. Bracey, Resolution of the Dominican Crisis, pp. 36-37.

66. While in London, Colonel Caamano remained secluded and isolated from the diplomatic community. In 1973 he was killed by Dorninican armed forces while atternpting to return to the island secretly with a small band of conspirators from Cuba. Msg, AMEMBASSY London to State, 5 Apr 67, sub: Col. Caamano, in Bennett personal papers, file 58, box 4418 83D 358; Msg, OAS Ad Hoc Committee to President of the Organization, 24 Jan 66,- in OAS 
Columbus Memorial Library, file OEA, ser. F/II.10, doc. 270-463; Department of the Army, "Stability Operations," p. 7.

67. Ltr, Chief of Dominican National Police to representatives of the Inter-American Commission on Human Rights, 15 Feb 66, in OAS Columbus Memorial Library, file OEA, ser. F/II.10, doc. 270-463.

68. Ltr, Garcia-Godoy to Comision Ad-Hoc de la OEA, 7 Jan 66, in Bunker personal papers, file: Ambassador's Military Folder (old), box 14383 67D291; Ferguson, "The Dominican Intervention of 1965," p. 536; Bracey, Resolution of the Dominican Crisis, p. 40.

69. Henry Wells, ed., Dominican Republic Election Factbook (Washington, D.C.: Institute for the Comparative Study of Political Systems, 1966), p. 8.

70. OAS, "Report Presented by the Mission of Observers to the President of the Organization" (Washington, D.C.: Pan American Union, 2 Jun 66), in OAS Columbus Mernorial Library, file OEA, ser. F/II.10, doc. 270-463; Memo, Bunker, 21 Jun 66, sub: Members of Thomas Group, in Bunker personal papers, file: Commissions and Missions, Thomas Mission, box $1438367 \mathrm{D} 291$.

71. Johnsrud, "Was Peace Victorious?" p. 15.

72. Palmer oral history, p. 185.

73. OAS, "Resolution on the Withdrawal of the IAPF from the Territory of the Dominican Republic," doc. 461 (Washington, D.C.: Pan American Union, 27 Jun 66), in Bunker personal papers, file: Withdrawal of IAPF, box 14384 $67 \mathrm{D} 291$.

74. Washington Center, National Support, pp. 311-12.

75. OAS Ad Hoc Committee, "Special Report of the Ad Hoc Committee of the Tenth Meeting of Consultation of Ministers of Foreign Affairs of the American States," 15 Sep 66, in Bunker personal papers, file: Withdrawal of IAPF, box $1438467 \mathrm{D} 291$.

76. Iturralde Chinel, Revolucion Dorninicana, p. 186.

77. Washington Center, National Support, pp. 289-313. 


\section{Conclusion}

Analyzing the overall Dominican operation requires consideration of more than the success or failure of military actions. There was never any real doubt that the $82 \mathrm{~d}$ Airborne Division could militarily subdue either or both factions in the civil war. Considering the overwhelming U.S. military strength and resources, the battle could have been ended anytime President Johnson desired, had he chosen a purely military solution. Instead, he chose to pursue a diplomatic solution through the Organization of American States, to use military force as his means rather than his end. Throughout the intervention, the U.S. military role changed frequently with regard to neutrality toward the combatants, to freedom of action, and to intensity. Each stage (initial evacuation of U.S. and foreign civilians, stability operations, and unilateral and multilateral peace-keeping) required separate and distinct actions by the $82 \mathrm{~d}$ Airborne Division and General Palmer. During each of these phases, political considerations dictated the manner, intensity, and scope of military operations. The intervention graphically displayed the manner in which military force must be integrated into political policy to achieve a desired solution. Therefore, an examination of the political and political-military results of the intervention is essential to assess the operation properly.

The U.S. Army was employed both independently and as part of a multilateral peace-keeping force in the 1965 Dominican intervention to stabilize conditions and maintain the peace to facilitate reinstatement of democracy. Its combat role was limited both in duration and in the application of force. The $82 \mathrm{~d}$ Airborne Division's major role was that of peace-keeping and maintaining a buffer between the combatants in Santo Domingo. The division shared the stage with State Department representatives in Washington, the Organization of American States, and the U.S. embassy in Santo Domingo. And the military played a supporting role to diplomatic efforts by the United States and the Organization of American States. General Palmer addressed the singular position in which his forces had been placed in a speech he prepared for an Association of the United States Army meeting in October of 1966: "The solution of the problem of a nation [does] not necessarily lie in the defeat of a 
specific political faction, but may well spring from dealing with the source of the problem -- the economy and welfare of the nation and its people. Thus, our military task in stability or national development operations may of ten be to control opposing factions and bring about an atmosphere of tranquility and stability."1

\section{Political Operations}

The United States and the Organization of American States shared the political objective of establishing a democratic government that could operate in relative peace and tranquility. The free elections of 1966 , following the establishment of the provisional government the preceding September, came as a direct result of this joint objective's being achieved. A second Cuba, as President Johnson had phrased it, had been avoided. For the people of the Dominican Republic, the intervention had succeeded in restoring the democratic process. A stable Dominican government materialized, in later years avoided coups as the means to change power, and continued to be antiCommunist if not always pro-American. Subsequent governments reduced the Dominican military's political influence and changed its role to emphasize maintaining internal security rather than repelling foreign invasion, its intended role before 1965.

Within Latin America, the intervention both created and destroyed. The Organization of American States gained regional and international prestige by providing the diplomatic forum which ended the rebellion. 2 By forming the Inter-American Peace Force, the organization showed the world that it was capable of policing internal problems without outside interference. The peace force proved, if only for this one event, that the OAS nations could work together toward a common goal. That the organization was forced into action by the U.S. unilateral military intervention or that the peace force was predominantly American is of little consequence. The perception of OAS action existed, and in international politics, perceptions of ten carry as much weight as facts.

However, the U.S. intervention damaged political relationships within the western hemisphere - causing wounds which remain unhealed. When the 3d 
Brigade of the 82d Airborne Division landed at San Isidro on 30 April 1965, twenty years of American-Latin American foreign policy changed. Latin nations that believed the United States had finally abandoned its policy of interventionism were stunned and outraged at the unilateral action. Their rekindled suspicions of the United States have yet to be extinguished.

The intervention also caused deep rifts within the United States, especially between the Congress and the chief executive. Initial public support for the evacuation soon gave way to opposition to the Army's combat and stability roles. Johnson based his early public appeals on the need to protect American lives, and only later did he introduce a Communist threat that he never substantiated. While self-defense actions seemed reasonable and well explained, those concerning Communist influence were often vague and accompanied by exaggerations and half-truths. Neither the public nor the news media were quick to accept the CIA lists or many of Johnson's statements concerning Communist infiltration and control of the Constitutionalist movement. Journalists were quick to investigate the president's assertions and publish their own, of ten contradictory, findings. ${ }^{3}$

\section{Military Operations}

President Johnson gave General Palmer the missions of protecting American lives, preventing a Communist takeover of the government, establishing a stable atmosphere, and assisting OAS negotiations. He accomplished each of these objectives. Not one American who remained in Santo Domingo following the Marine evacuations on 27 and 28 April lost his life to revolutionary violence after the Army arrived. The violence, however, did not stop. Three thousand Dominicans lost their lives either to fighting between the two political factions or in battles with the $82 \mathrm{~d}$ Airborne Division during this same period. ${ }^{4}$ The rapidity and relatively large scale of the $82 \mathrm{~d}$ 's deployment to the Dominican Republic stunned the rebellion and quickly led to the physical separation of the factions. The Army's arrival bolstered Loyalists' morale and gave them back a will to fight the extremist elements that were attempting to seize the revolution from the Dominican Revolutionary Party. The only area in which the division's rapid deployment failed to meet the 
president's expectations was in the political arena, not on the field of battle. 5 Johnson never expected the intense level of domestic opposition to his interjection of the Army into the Dominican Civil War.

Despite avoidable shortcomings with initial intelligence and planning, the Army carried out all combat operations with efficiency and minimal collateral damage. After establishing the line of communication on 3 May, U.S. forces quickly adapted to their roles as peace-keepers and providers of humanitarian aid for the people of Santo Domingo. Late in May, General Palmer directed a change in the rules of engagement. The soldier, who had previously been allowed to "return fire when fired upon," was then required to "take cover and not fire unless the position was in danger of being overrun or American lives [were] in extreme danger." 6 The disciplined and informed paratroopers handled the frequently changing definition of neutrality remarkably well. Begun as proLoyalist, the operation shifted close to neutrality after the line of communication was established, achieved true neutrality following the rebel offensive of mid-June, and finally became pro-provisional government with its formation in late October. At every step the soldiers knew what General Palmer expected from them, and they responded accordingly.

The incorporation of elements of the $82 \mathrm{~d}$ Airborne Division into the InterAmerican Peace Force in late May was handled effectively, thanks in great measure to the preparations Palmer made in establishing a cadre staff. Similar theories of military organization and staff procedures, as taught by the U.S.sponsored inter-American military education system, helped smooth operations within the headquarters and promoted a general feeling of common purpose and camaraderie among the staff. While the Army assigned competent officers to man the U.S. positions on the staff, many had never dealt with Latin officers and literally could not speak their language.

The Latin elements of the peace force conducted themselves well both in handling direct military threats and in resisting temptations to respond to provocation from Communist-inspired crowds and propaganda. Although many arrived with minimum personal equipment and remained totally dependent on the United States for logistics, their effectiveness increased throughout the operation. Brazilian actions during the rebel offensive of 15 June demonstrated Latin discipline and dedication to the inter-American mission. 


\section{Summary}

From the operation's onset, U.S. policy makers viewed military force as a means through which political ends could be achieved. The $82 \mathrm{~d}$ Airborne Division was used to capture objectives which would strengthen American or OAS political positions rather than to clear the entire field of battle. That is, the military mission remained flexible and changed several times during the operation to speed an eventual political solution. The separation of the combatants and the prevention of the spread of hostilities outside of Santo Domingo brought about a military stalemate between the Loyalists and Constitutionalists which, in turn, led to negotiation. The division's presence then preserved relative tranquility and gave the factions time and incentive to form the provisional government and eventually to hold elections the following June.

At every step along the way, General Palmer and the $82 \mathrm{~d}$ Airborne Division were called upon to use different methods of operation. Rules of engagement were changed to emphasize increased levels of restraint and neutrality as the intervention progressed. Humanitarian aid and order replaced combat as the essential mission for the division once stability had been achieved in Santo Domingo. ${ }^{7}$ At each step and change of mission, General Palmer supported the political goals of the president and secretary of state first, and military expediency second. The $82 \mathrm{~d}$ Airborne Division rapidly deployed en masse to the Dominican Republic and, possessing the discipline and self-restraint to adapt quickly to changing political environments, was the catalyst for the eventual diplomatic solution to the civil war. General Palmer's thorough understanding of his role, his ability to work closely with Ambassadors Bunker and Bennett, and the discipline and restraint displayed by the $82 \mathrm{~d}$ Airborne's individual soldier during the seventeen-month-long operation ended the 1965 Dominican Civil War and returned the country from the brink of collapse. 


\section{Notes - Chapter V}

1. Speech, Lt Gen Bruce Palmer, Jr., for AUSA Mtg, 26 Oct 66, Washington, D.C., sub: US Stability Operations in the Dominican Republic, private papers collection, Military History Institute, Carlisle Barracks, Pa., p. 17.

2. Memo, State Dept, 4 May 65, sub: Minutes of Meeting, National Security Council History, Dominican Republic Intervention, LBJ Library, Austin, Tex., p. 2.

3. Throughout the intervention several prominent journalists took exception with administration claims about the depth of Communist participation in the revolution. Tad Szulc and Peter Kihrs, both writing for the New York Times, ran several series that challenged Johnson's statements throughout the summer of 1965. In the United States, public distrust was evident in statements made by congressional leaders opposed to Johnson's Dominican policy. These congressmen included Representative Rayburn and Senators Fulbright, Clark, and Morse.

4. By mid-September 1965 U.S. forces had successfully evacuated nearly 5,000 civilians from 46 nations from Santo Domingo. Of this total, approximately one-half were Americans. Speech, Amb. W. Tapley Bennett, Jr., to the Professional Groups Active in Journalism and Public Relations, 17 Sep 65, at Atlanta, Ga., in personal papers of Amb. Ellsworth Bunker, file: Speeches, box 14383 67D291, U.S. Department of State historical files, Washington, D.C.; Yale H. Ferguson, "The Dominican Intervention of 1965: Recent Interpretations," International Organization 27 (Autumn 73): 539.

5. Elbert E. Legg, "The US Military Role in Coping with a Sudden Revolt in the Dominican Republic" (Carlisle Barracks, Pa.: U.S. Army War College, 4 Jan 68), p. 10.

6. William E. Klein, "Stability Operations in Santo Domingo," Infantry 56 (May-Jun 66): 38.

7. Humanitarian support for the Dominican people was wide ranging and varied. General support included trash and garbage removal, water, incinerator operations, orphanage assistance, farm grain supply, food distribution, care of zoo animals, roads and irrigation systems, fuel distribution, clothing, wells, transportation services, and films and movies. For a complete and concise discussion of the humanitarian aid provided by U.S. Forces, Dominican Republic, see Ltr, Linvill to Bunker, 15 Apr 66, sub: Civic Action Program and Psychological Operations in the Dominican Republic, and L tr, Linvill to Bunker, 12 May 66, sub: Report of Civic Action Activities, both in Bunker personal papers, file: Correspondence with USFORDOMREP, box $1438367 \mathrm{D} 291$. 


\section{APPENDIX}

\section{Who's Who}

\section{Dominicans}

Alvarez Holguin, Lt. Col. Pedro Augusto (Army)

Commander of 16 th of August Camp at outbreak of civil war; one of three officers who started rebellion against Reid government

Aristy, Hector Chief adviser to Colonel Caamano during revolution and man who assumed de facto power among rebel fighting forces

Balaguer, Joaquin Right-of-center figurehead president at end of Trujillo era; head of first council of state after Trujillo assassination until mid-January 1962; elected to presidency 1 June 1966, defeating Bosch and Bonnelly; now leads Reformist Party

Benoit, Col. Pedro Bartolome (Air Force) President of San Isidro junta established 27 April 1965; made official call for U.S. military assistance

Bonnelly, Rafael

Right-wing president from 1962 until 27 February 1963; headed second council of state after Balaguer deposed; unsuccessful candidate for president in June 1966 election

Bosch, Juan

President from February 1963 until ousted by coup in September 1963; formed Dominican Revolutionary Party while in exile in Puerto Rico; unsuccessful candidate for presidency in June 1966; current head of leftwing political party

Caamano Deno, Lt. Col. Francisco (Army)

Adviser to Reid who became leader of rebel elements of revolution; Constitutionalist president in 1965; pro-Bosch; died in aborted coup attempt in 1973

Clarizo, Msgr. Emanuel

Papal nuncio to Dominican Republic and dean of diplomatic corps; played decisive role in commencing negotiations between Constitutionalists, Loyalists, and OAS representatives

de los Santos Cespedes, Brig. Gen. Jesus

Commander of Dominican Air Force in 1965; first to strike against rebels 
Garcia-Godoy, Hector

Dominican businessman and diplomat; provisional president from 3

September 1965 to 1 July 1966 after signing of Act of Reconciliation

Guzman, Silvestre Antonio

Member of Dominican Revolutionary Party suggested but not accepted for provisional president; vice-presidential candidate with Bosch in June 1966

election; became president in May 1978 and held office until August 1983

Hernando Ramirez, Lt. Col. Miguel Angel (Army)

Commander of 27 th of February Camp at start of rebellion against Reid; his were first troops to rebel and call for return of Juan Bosch

Imbert Barrera, General Antonio

Surviving assassin of Trujillo; head of Government of National Reconstruction May-August 1965; replaced by provisional government of Garcia-Godoy

Molina Urena, Jose Rafae!

Provisional president of Constitutionalist government for two days before fleeing to Colombian embassy; member of Bosch's Dominican Revolutionary Party

Reid Cabral, Donald "Donny"

Head of triumvirate and provisional president from 25 September 1963 until start of civil war on 25 April 1965; considered pro-U.S. moderate

Rivera Caminero, Commodore Francisco

Commander of Dominican Navy and later secretary of armed forces in both Government of National Reconstruction and provisional government

Wessin y Wessin, Brig. Gen. Elias

Right-wing leader of Loyalists; commander of training center at San Isidro Airfield; leader of coup which overthrew Bosch in 1963; forced to retire by Garcia-Godoy and Inter-American Peace Force

\section{Brazilians}

Alvim, General Hugo Panasco

Initial commander of Inter-American Peace Force from May 1965 to January 1966

Braga, Brig. Gen. Alvaro de Silva

Replaced General Alvim as peace force commander and served until disbandment in September 1966 


\section{Americans}

Department of the Army Staff, April 1965

Vice Chief of Staff

Secretary of the Army

Assistant Chief of Staff

for Operations (Plans and Operations) Maj. Gen. A.S. Collins, Jr.

Chief of Staff

Deputy Chief of Staff for Operations and Plans

Assistant Chief of Staff for Operations (Special Operations)

Under Secretary of the Army

Chief, Western Hemisphere

General Creighton W. Abrams

Stephen Ailes

General Harold K. Johnson

Lt. Gen. Bruce Palmer, Jr.

Maj. Gen. W.R. Peers

Stanley Resor

Col. E.A. Rundquist

Ball, George w.

Under secretary of state

Bennett, W. Tapley, Jr.

U.S. ambassador to Dominican Republic March 1964-April 1966

Bundy, McGeorge

Special assistant to President Johnson for national security affairs; chief of U.S. mission to form provisional government

Bunker, Ellsworth

U.S. ambassador to the Organization of American States; dominant member of OAS ad hoc committee

Connett, william B., Jr.

Counselor at U.S. embassy in Santo Domingo; deputy chief of U.S. mission; charge d'affaires for first three days of civil war

Dare, Capt. James A. (Navy)

Commander, Task Force 44.9

Mann, Thomas C.

Under secretary of state for economic affairs; President Johnson's key Latin American adviser

Martin, John Bartlow

Former U.S. ambassador to Dominican Republic; special envoy for President Johnson

McNamara, Robert S.

Secretary of defense 
Moorer, Admiral Thomas $\mathrm{H}$.

Cornmander in Chief, Atlantic, after 30 April 1965

Palmer, Lt. Gen. Bruce, Jr.

Became commander of U.S. Forces, Dominican Republic, and deputy commander of Inter-American Peace Force; later vice chief of staff and acting chief of staff, 1972-73

Quilty, Col. Joe (Marine Corps)

Chief of U.S. Military Assistance Advisory Group in Santo Dorningo in 1965

Tompkins, Maj. Gen. R. McC. (Marine Corps)

Deputy commander of Joint Task Force 122; commander of Marine forces ashore

Vance, Cyrus R.

Deputy secretary of defense

Vaughn, Jack Hood

Assistant secretary of state for inter-American affairs

Wheeler, General Earle G.

Chairman, Joint Chiefs of Staff

York, Maj. Gen. Robert

Commander of 82d Airborne Division and first commander of U.S. Forces, Dominican Republic

\section{Major Dominican Political Parties}

Dominican Revolutionary Party (Partido Revolucionario Dominicano)

Democratic left formed by Bosch in 1939 while in exile; support from peasants, small landowners, urban workers, and urban poor; in 1962 won 60 percent of votes and elected Bosch to presidency; became factionalized and more leftist after 1965

National Civic Union (Union Civica Nacional)

Founded before December 1962 elections; anti-Trujillo businessmen and professionals; supported anti-Bosch coup in 1963 and Imbert in 1965; suffers from factionalization between moderates and extremists

National Integration Movement (Movimiento de Integracion Nacional)

Founded February 1966 to promote Rafael Bonnelly; moderate conservative party with right-of-center support; opposition party for Dominican Revolutionary Party and Reformist Party 
Reformist Party (Partido Reformista)

Formed in 1963 with Balaguer as head and legally recognized in 1964; vehicle for Balaguer to seek presidency; right-of-center and rural support

14 th of June Revolutionary Movement (Movimiento Revolucionario 14 de Junio) Named for aborted Cuban-sponsored invasion in 1959; resistance movement to Trujillo and strongly Castroite; split from National Civic Union; supported Bosch and had representation in Garcia-Godoy government 


\section{BIBLIOGRAPHY}

\section{Books}

Aguilar, Luis E. Latin America 1983. Washington, D.C.: Stryker-Post Publications, 1983.

Atkins, G. Pope. Arms and Politics in the Dominican Republic. Boulder, Colo.: Westview Press, 1981.

Ball, M. Margaret. The OAS in Transition. Durham, N.C.: Duke University Press, 1966.

Barnet, Richard J. Intervention and Revolution. New York: New American Library, 1968.

Barry, Robert F., ed. Power-Pack. Portsinouth, Va.: Messenger Printing Co., 1982.

Blechman, Barry M., and Kaplan, Stephen S. Force Without War. Washington, D.C.: Brookings Institute, 1978.

Bosch, Juan. The Unfinished Experiment: Democracy in the Dominican Republic. New York: Praeger, 1965.

Carey, John, ed. The Dominican Republic Crisis 1965. Dobbs Ferry, N.Y.: Oceana Publications, 1967.

Child, John. Unequal Alliance: The Inter-American Military System, 1938-1978. Boulder, Colo.: Westview Press, 1980.

Draper, Theodore. The Dominican Revolt: A Case Study in American Policy. New York: Commentary, 1968.

Fehrenbach, T.R. This Kind of War. New York: Macmillan, 1963.

Gleijeses, Piero. The Dominican Crisis: The 1965 Constitutionalist Revolt and American Intervention. Baltimore: Johns Hopkins University Press, 1978.

Gurtov, Melvin. The United States Against the Third World. New York: Praeger, 1974.

Gutierrez, Carlos Maria. The Dominican Republic: Rebellion and Repression. New York: Monthly Review Press, 1972. 
Hansen, Harry, ed. The World Almanac 1964. New York: New York World Telegram, 1964. 1965.

The World Almanac 1965. New York: New York World Telegram,

Johnson, Lyndon Baynes. The Vantage Point. New York: Holt, Rinehart and Winston, 1971 .

Lowenthal, Abraham F. The Dominican Intervention. Cambridge, Mass.: Harvard University Press, 1972.

Mallin, Jay. Caribbean Crisis: Subversion Fails in the Dominican Republic. Garden City, N.J.: Doubleday, 1965.

Mansbach, Richard W., ed. Dominican Crisis 1965. New York: Facts on File, 1971 .

Martin, John Bartlow. Overtaken by Events. New York: Doubleday, 1966.

Millet, Allan Reed. The Politics of Intervention. Columbus: Ohio State University Press, 1968.

O'Brien, William V. The Conduct of Just and Limited War. New York: Praeger, 1981.

Organization of American States. Fuerza Interamericana De Paz. Washington, D.C.: Pan American Union, 1966.

Slater, Jerome. Intervention and Negotiation: The United States and the Dominican Republic. New York: Harper and Row, 1970.

- The OAS and United States Foreign Policy. Columbus: Ohio State University Press, 1967.

Support the Dominican People's Resistance to U.S. Armed Aggression. Peking: Foreign Languages Press, 1965.

Szulc, Tad. Dominican Diary. New York: Delacorte Press, 1965.

Weil, Thomas E., et al. Area Handbook for the Dorninican Republic. Washington, D.C.: Government Printing Office, 1973.

Weil, Thomas E.; Black, Jan Knippers; et al. Dominican Republic: A Country Study. 4 th ed. Washington, D.C.: Government Printing Office, 1982.

Welles, Sumner. Naboth's Vineyard. 2 vols. New York: Payson and Clarke, 1928. 


\section{Periodicals}

Barrett, Raymond J. "Inter-American Peace Force." Military Review 47 (May 1967): 85-91.

Bender, L.B. "Dominican Intervention: The Facts." National Review 18 (February 8, 1966): 112-14.

Bethel, Paul D. "Dominican Intervention: The Myths." National Review 18 (February 8, 1966): 107-111.

Black, Robert A. "Inter-American Security." USMC Gazette 49 (September 1965): 51-54.

"Century Club Wings Awarded in Dominican Republic." Airborne Quarterly (Autumn 1965): 20.

Dare, James A. "Dominican Diary." Proceedings (December 1965): 36-45.

Draper, Theodore. "The Dominican Crisis: A Case Study in American Policy." Commentary 79 (December 1965): 33-64.

- "The Dominican Intervention Reconsidered." Political Science Quarterly 85 (March 1971): 1-36.

Ferguson, Yale H. "The Dominican Intervention of 1965: Recent Interpretations." International Organization 27 (Autumn 1973): 517-43.

Klein, William E. "Stability Operation in Santo Domingo." Infantry 56 (May-June 1966): 35-39.

Langley, Lester D. "Military Commitments in Latin America: 1960-1968." Current History 56 (June 1969): 346-51.

Lewy, Guenter. "The Proprieties of Military Intervention." Parameters 11 (June 1981): 2-8.

Moskos, Charles C., Jr. "Grace Under Pressure." Army 16 (September 1966): 9.

"Operation DOM-REP." Airborne Quarterly (June-August 1965): 13-15.

Rabe, Stephen G. "The Johnson (Eisenhower) Doctrine for Latin America." Diplomatic History 9 (Winter 1985): 95-100.

"The Role of Investment in Latin America's Economic Future." U.S. State Department Bulletin (February 1985): 36-43. 
"Security Council Authorizes U.N. Representative in Dominican Republic." U.S. State Department Bulletin (May 31, 1965): 869-85.

Slater, Jerome. "The United States, the OAS, and the Dominican Republic 196163." International Organization 18 (Spring 1964): 268-91.

"Statements and Diplomatic Notes of Ambassador Ellsworth Bunker to Tenth Meeting of Consul of Foreign Ministers of the American Republics." U.S. State Department Bulletin (June 7, 1965): 1354.

Szulc, Tad. "When the Marines Stormed Ashore in Santo Domingo." Saturday Evening Post (July 31, 1965): 36-\$6.

Taylor, Telford. "Military Intervention in Civil Wars: Do Law and Morality Conflict?" Parameters 11 (June 1981): 9-14.

Tompkins, R. McC. "Ubique." USMC Gazette 49 (September 1965): 34-39.

\section{Reports}

Andrews, John H. "The Dominican Intervention 1965-66." Student paper. Ft. Leavenworth, Kan.: U.S. Army Command and General Staff College, 1 March 1982.

Atkins, G. Pope. Mutual Security in the Changing Inter-American System: An Appraisal of OAS Charter and Rio Treaty Revisions. Carlisle Barracks, Pa.: Strategic Studies Institute, 1977.

Ault, John W., Jr. "Dorninican Republic Crisis: Causes, Intervention, Lessons Learned." Student research study. Ft. Leavenworth, Kan.t U.S. Army Command and General Staff College, May 1970.

Bentley, David A. "Political Stability in the Dominican Republic: An Outlook for the Future." Student paper. Ft. Bragg, N.C.: Foreign Area Officer Course, U.S. Army John F. Kennedy Center, 20 March 1984.

Blechman, Barry M., and Kaplan, Stephen S., eds. Intervention in the Dominican Republic, 1961-66. Washington, D.C.: Brookings Institute, December 1976.

Bracey, Audrey. Resolution of the Dominican Crisis, 1965: A Study in Mediation. Washington, D.C.: Institute for the Study of Diplomacy, 1980.

Center for Strategic Studies. Dominican Action - 1965: Intervention or Cooperation. Special Report Series No.2. Washington, D.C.: Georgetown University, July 1966.

Child, Jack. "Post-War US Strategy Planning for Latin America (1945-76): from 'Rainbow' to 'IDAD'." Report presented to Eleventh Military History 
Symposium, U.S. Air Force Academy, Colorado Springs, Colo., October 1984.

Clark, W. K. "Military Contingency Operations: The Lessons of PoliticalMilitary Coordination." Student thesis. Ft. Leavenworth, Kan.: U.S. Army Command and General Staff College, 1975.

Condit, D. M.; Cooper, Bert H., Jr.; et al. Challenge and Response in Internal Conflict. Washington, D.C.: Center for Research in Social Systems, September 1968.

Costa, John J. "The Dominican Republic: Intervention in Perspective." Student paper. Ft. Leavenworth, Kan.: U.S. Army Command and General Staff College, 2 May 1968.

Department of the Army, Office of the Chief of Staff. "Caribbean Basin: Areas of Army Concern/Interest -- Politico-Military Perceptions." Information paper. Washington, D.C.: Department of the Army, 22 March 1985.

- Challenge: Compendium of Army Accomplishments: A Report by the Chief of Staff. Washington, D.C.: Departinent of the Army, July 64-April 68. Secret.

. "Stability Operations Dominican Republic," Pts. 1 and 2, Vol. IV. Washington, D.C.: Department of the Army, 28 January 1971.

. XVIII Airborne Corps. "Stability Operations Report, Dominican Republic (Part III)." Ft. Bragg, N.C.: Headquarters, XVIII Airborne Corps, 1 October 1966.

"The Dominican Intervention 1965." Carlisle Barracks, Pa.t U.S. Army War College, 1984.

The Economist Intelligence Unit. Quarterly Economic Review of Cuba, Dominican Republic, Haiti, Puerto Rico. No. 4, 1984. London: Spencer House, 1984.

- Annual Supplement 1984. London: Spencer House, 1984.

Ellsworth, Harry Alanson. "One Hundred Eighty Landings of United States Marines, 1900-1934: A Brief History." Unpublished study, 1934. In U.S. Marine Corps History Office, Washington, D.C.

Galati, Frank E. "Military Intervention in Latin America: Analysis of the 1965 Crisis in the Dominican Republic." Student thesis. Ft. Leavenworth, Kan.: U.S. Army Command and General Staff College, 1983.

Hinrichs, Ralph W., Jr. "United States Involvement in Low Intensity Conflict Since World War II: Three Case Studies - Greece, Dominican Republic and Vietnam." Student thesis. Ft. Leavenworth, Kan.t U.S. Army Command and General Staff College, 1984. 
Iturralde Chinel, Luis. La O.E.A. y la Revolucion Dominicana. Washington, D.C.: Union Panamericana, 1967. In OAS Columbus Memorial Library, Washington, D.C.

Johnsrud, Melvin H. "In the Dominican Crisis, Was Peace Victorious?" Student thesis. Ft. Leavenworth, Kan.: U.S. Army Command and General Staff College, 1968.

Krickus, Richard J. The Control of Local Conflict: Case Studies, Vol. Il: Latin America. Waltham, Mass.: Bolt Bernanek and Newman, August 1969.

Legg, Elbert E. "The US Military Role in Coping With a Sudden Revolt in the Dominican Republic." Student thesis. Carlisle Barracks, Pa.: U.S. Army War College, 4 January 1968.

Long, Eldredge R., Jr. "The Dominican Crisis 1965: An Experiment in International Peace Keeping." Student thesis. Newport, R.I.: U.S. Naval War College, 1967.

Lowenthal, Abraham F. The Dominican Republic: The Politics of Chaos. Washington, D.C.: Brookings Institute, 1969.

Marcella, Gabriel. Dimensions of US-Latin American Military Relations. ACN 78062. Carlisle Barracks, Pa.: U.S. Army War College, 5 September 1978.

- Latin America in the 1980's. ACN 81048. Carlisle Barracks, Pa.t U.S. Army War College, 15 June 1983.

Mayer, Edward E. "The Dominican Crisis -- 1965." Student thesis. Carlisle Barracks, Pa.: U.S. Army War College, 8 April 1966. Secret.

Office of the Joint Chiefs of Staff. Chronology of the Crisis in the Dominican Republic. Washington, D.C.: Historical Division, Joint Secretariat, 30 September 1966. Top Secret.

Organization of American States. Annual Report of the Secretary General 1965. Washington, D.C.: Pan American Union, 1966.

- "Documents of the Consultation of the Organization Relating to the Tenth Meeting of Consultation of Ministers of Foreign Affairs." Washington, D.C.: Pan American Union, 1965.

- "First Report of the Special Committee of the Tenth Meeting of Consultation of Ministers of Foreign Affairs." Doc. 47, rev. Washington, D.C.: Pan American Union, 2 June 1965.

- "Minutes of Meeting of Consultation of Ministers of Foreign Affairs of American States, Tenth." Washington, D.C.: Pan American Union, \& August 1965. 
- "Report on the Dorninican Republic Emergency Aid Operation up to

June 30, 1965." Washington, D.C.: Pan American Union, 12 August 1965.

- "Report Presented by the Mission of Observers to the President of the Dominican Republic." Washington, D.C.: Pan American Union, 2 June 1966.

. "Resolution on the Withdrawal of the Inter-American Peace Force From the Territory of the Dominican Republic." Washington, D.C.: Pan American Union, 24 June 1966.

. "Resolutions Approved by the Tenth Meeting of Consultation of Ministers of Foreign Affairs as of June 2, 1965." Doc. 78, rev. 5. Washington, D.C.: Pan American Union, 7 June 1965.

. "Second Report of the Special Committee of the Tenth Meeting of Consultation of Ministers of Foreign Affairs." Doc. 81, rev. Washington, D.C.: Pan American Union, 2 June 1965.

Perez-Poveda, Gustavo. "The Dominican Republic: Will a Democratic Tradition Take Root?" Student paper. Ft. Bragg, N.C.: Foreign Area Officer Course, U.S. Army John F. Kennedy Center, September 1984.

Poole, Walter S. The History of the Joint Chiefs of Staff: The Joint Chiefs of Staff and National Policy, Vol. IX: 1965-1968. Washington, D.C.: Historical Division, Joint Secretariat, May 1985. Top Secret.

Rosenblum, Donald E. Decisionmaking for Intervention. Staff study. Carlisle Barracks, Pa.t U.S. Army War College, 20 February 1969.

Schoonmaker, Herbert G. "United States Military Forces in the Dominican Crisis of 1965." Doctoral dissertation. A thens: University of Georgia, 1977.

Scott, Leslie Andrew. "The Dominican Republic Crisis, 1965: Military Intervention as an Instrument of American Foreign Policy." Maxwell AFB, Ala.: Air War College, March 1977.

Sereseres, Caesar D. The Future of US Military Diplomacy in the Hemisphere. ACN 77040. Carlisle Barracks, Pa.: U.S. Army War College, 11 November 1977.

Smith, Paul E. "The United States Military Assistance Program in the Dominican Republic 1953-1965: A Lesson Learned?" Student essay. Carlisle Barracks, Pa.: U.S. Army War College, 18 January 1968.

Stevens, Kenneth T. "What Does it Mean to Win in the Dominican Republic?" Student paper. Ft. Leavenworth, Kan.: U.S. Army Command and General Staff College, 1966. 
United States Army War College. Case Study 5-01, Dominican Republic. Carlisle Barracks, Pa.: U.S. Army War College, 2 January 1968.

United States Congress, Senate, Committee on Foreign Relations. "Background Information Relating to the Dominican Republic." 89 th Cong., 1st sess. Washington, D.C.: Government Printing Office, July 1965.

United States Department of State. "Background Notes: Dominican Republic." Washington, D.C.: Government Printing Office, October 1981.

. "The Dorninican Crisis: The Hemisphere Acts." Inter-American Series 92. Washington, D.C.: Government Printing Office, October 1965.

. "Dominican Republic: Post Report, June 1983." Washington, D.C.: Government Printing Office, June 1983.

United States Forces, Dominican Republic. "Report of Stability Operations, Dominican Republic." Santo Domingo: Headquarters, U.S. Forces, Dominican Republic, 31 August 1965.

Washington Center of Foreign Political Research. National Support of International Peacekeeping and Peace Observation Operations. Vol. V. Washington, D.C.: Johns Hopkins University, February 1970.

Wells, Henry, ed. Dominican Republic Election Factbook. Washington, D.C.: Institute for the Comparative Study of Political Systems, 1966.

Wiarda, Howard J. "From Fragmentation to Disintegration: The Social and Political Effects of the Dominican Revolution." Paper presented at Southern Political Science Association Convention, Gatlinburg, Tenn., 1012 November 1966. In U.S. Army War College, Carlisle Barracks, Pa.

\section{Private Papers}

Oral History of General Bruce Palmer, Jr. U.S. Army Military History Research Collection, Senior Officers Debriefing Program. Carlisle Barracks, Pa.: Military History Institute, 1976.

Oral History of Cyrus R. Vance. In Johnson Memorial Library, Austin, Tex.

Private papers of Ambassador W. Tapley Bennett, Jr. In U.S. Department of State Archives, Washington, D.C.

Private papers of Ambassador Ellsworth Bunker. In U.S. Department of State Archives, Washington, D.C.

Private papers of General Bruce Palmer, Jr. In U.S. Army Military History Research Collection. Carlisle Barracks, Pa.: Military History Institute. 
Act Establishing the Inter-American Peace Force, I)

Act of Santo Domings, 49-50

Acts of Reconciliation and lestitutional Act, 7 .

Airctaft

C-1 $30,37,39$

EC-135, 39

$\mathrm{F}=4,39$

$\mathrm{F}-100,4 \mathrm{4}$

$F=100$, of

P-51, 16, 50

RB -66, at

RF-10i, 40

All American Expressway, 47

Altiance for Progress, 23-24, 63

Alvim, General hugo Panasco, 70, 72, 73, 78, 79, 82,83

Arache, Col. Montes, 53

Argentina, 24

humanitarian aid, 69

manaing of peace force, 69

in OAS special committee, 63

reaction to landing of Marines, 62

resolution establishing pesce force, 6 ?

Armed Forces Training Center, 8, 9, 13-19, 40, 50, 78

Atlantic Command. See Commander in Chief, Atlantic.

Baez, Buenaventura, 3

Balaguer, Joaguin, 6-8, $12 \mathrm{n} .22,83$

Ball, George $\mathrm{z} . ., 14,18,22$

Barahona, 80

Bay of Pigs, 24

Bennett, $\%$. Tapley, $\mathrm{rr}_{n=}, 10,13,16,28 \mathrm{n} .27,50,73$, 78

communications with Washington, 18, 20-22, 42

evacuation of civilians, 18,39

plan to separate combatants, 22, 39

relations with PaImer, 63,96

Benoit, Col. Pedro Bartolome, 49-50

as head of Loyalist junta, 20

requests for U.S. forces, $21,23 n .27$

Betancourt, Romulo, 6, 62, 69

Blanco, Castelo, 83

Blance, Salvador Jorge, 78

Bolivia, 10

humanitarian aid, 69,70

resolution establishing peace force, 6 ?

Donnelly, Rafael $F_{y,} 8,12 n-22,78,83$

Bosch, Juan, 8-9, 50, 53, 61, 83, 84. See alse

Dominican Revolutionary Party.

election to presidency, 20

exile, is

legalization of Communist parties, 14

epposition to, 24,36

support for, 13, 15, 22

Braga, Brig. Cen. Alvaro de Silva, 83, 84

Brazil, 77,95

humanitarian aid, 70

manning of peace force, $69,72,74,84$

naming of peace torce commander, 69

OAs special comisittee, 65

resolation establishing peace force, 6 ?
Brazilian Battalion. See Latin Arserican Brigade.

Bundy, McGeorge, 49

Bunker, Ellswor th, 77, 82

Johnsev's support of, 64

relations with Paliner, 96

role in OAS, 46, 49, 62-67, 69

Caainano, t.t. Gen. Fausto, IIn 1 I

Caamano Deno, Col. Francisco, 47, 53, 66, 76-78, $80,32,90 n-66$

Act of Santo Domingo, 49-50

captuare of Reid, 15-16

as Constitutionalist leader, 17-20

refinsal to negotiate with Imbert, 5 i

on U.S, neutrality, 51

Caeado Saladin, Col. Enrique Apotinar, 20

Caminero, Commodore Francisco Rivera, 16, 30

Camp David, 14

Camp LeJeune, 43

Camp Mella, 79

CARE, 70

Caribbean, 1

display of American force in, 7

threat of Communist expansion in, 24

U.S. policy toward, 23-26

Caritas, 70

Carrasco, Capt. Manuel Santana, 20

Castro, Fidel, 42, 53

Casualties, 34, 96, 34, 94

Cundillos, political legacy of, 3, 3

Cease-tires, 22, 50, 51, 63, 60, 65, 76

Central Intelligence Agency (CIA), 22, 25, 94

Chile

establishing International Security Zone, 64

establisting peace force, 67

opposition to intervention, 64

Clusech World Services, 70

Cinudad Nuevo, 44, 47, 51, 53, 76, 79, 80

Ciudad Trujillo,

Clarizo, Migr. Emanuel, 22, 63

Clark, Joseph, 26, 97n,3

Coco, Alejandro Zeller, so

Colombia

humanitarian aid, 70

manning of peace force, 69

OAs special committee, 65

resolution establishing peace force, 67

Colombo, Picardo, 65

Commander in Chief, Atlantic. See also Moorer, Adiniral Thomas A.

corninunications problems, 36-37

Naval Task Group 44.9, 32

Operation Plan $310 / 2,36$

POWER PACK $1,37,33,39$

Communist influence in Latin America, and U.S. fear of, $18,21-22,42,43,61-62,71$

Communist parties, Dominican, 15, 16, 1 ?

harassnent of, $12 \mathrm{n} .22,10$

legalization of, 8,14

at outbreak of civil war, 16

Congress, Dorninican, is

Congress, U.5., 21, 64, 76, 94, 97n.3

House of Representatives, 26

Senate

Foreign Relations Committee, 26 
oposition to intervention, 26

Connett, William B., Jr.

coenenunications with Washington, 14-18, 32-33

evacuation of civilians, 17-18, 32-33

Constitutionalists

adoption of name, 13

fighting with Loyalists, 37

fighting with U.S. forces, 31, 50, 51

neutralization of, $46,53,79-30,94,96$

offensives, $76-77,32,83,95$

provisional governinent, 17,78

radicals in, $26,61,66$

successes, $13,15,17,20,43,44$

U.S. hopes to dernorallize, $34,46,77$

Costa, Lt. Col. John, 82

Costa Rica

manning of peace force, $69,72,73,84,88 n .36$

resolution establishing peace force, 67

Council of state, 8

Cuba, $43,44,51,53,90 \mathrm{n}, 66$

Comminist takeover, 7,24

expulsion from OAS, $25,62,64$

revolutionury model, 21, 22, 93

Cuban missile crisis, 24

Cuello, Julio, 50

Dare, Capt. James A., 17, 23, 32, 33, 39

Daugherty, Col. George $\mathrm{w}_{\text {. }} 34$

de Caceres, Jose Nunez, 3

de ta Mara, Antonio, 6

de los Santos Cespedes, Brig. Gen. Jesus, 14, 90

Defense Condition 3, 36, 43

del Prado family, 3

del Resario, Francisco, 3

Dominican Air Force, 13, 14, 16, 20

Dominican armed forces, is

Dominican Army, 78

Dominican national police, $5,14-15,18,33,38,43$, $44,79,80$

Dominican Navy, 13, 10, 16, 18, 32, 33

Dominican provisional governinent, 93, 95, 96. See also Garcia-Godoy, Hector.

agreement establishing, 77

forination, 78

leadership, $77-78$

peace force support of, 79-83

U.5. diplomatic recognition of, 78

Dominican Revolutionary Par ty, 8, 13, 14, 16-17, $20,22,94$

Dominican Secret Police, 5-6, 19

Dereier, John, 61

Duarte, Juan Pablo, 3

Duarte Bridge, 15, 17, 18, 39, 40, 43, 46, 47, 78, 80

Duena, Ramon de Clairmont, 77

Ecuador, 24, 67

Eisenhower, Dwight D., 6, 8, 24

EI Salvador, $69,72,77$

Elections, Dorninican, 8, 9, 77, 80, 83-84, 93, 96

Embassy, U.Sy Santo Domingo, 43, 70, 92. See also Bennett, w. Tapley, Jr.i Connett, williain B., Jr.

Benoil request for help, 21

first re parts of civil war, 16

opin , i of Bosch, 8

Reid roquest for asylum, t6

securi $y+23,33,34,40,40$

Evacy on of U.S. and toreign civilians from Santo Do vingo, 17, 18, 20, 26, 31-34, 62, 65, 92, 94, $97,+4$
Fort Brase, 37, 92, 43, 74

Fortress Orama, 18, 43

15 th of June Revolutionary Movement, is

Prancisco Pena, Jose, 13

Fraternity Battalion. See Latin American Brigade.

Pulbright, 1. William, 26, 97n.3

Garcia-Godoy, Hector, $77,78,79,80,84$

Good Neighbor Policy, 23, 63

Government of National Reconstruction, 30,78

Grant, Ulyswes S., 3-4

Gevantanamo, 32

Guaternala, OAS special comnittee, 64

Guerrero, General Salvador Montas, is

Guzman, Antonio Silvestre, 78

Haina, port of, 31-34, 40, 62

Hait:

invasion of Santo Domingo,

manning of peace force, 69

Harriman, Averell, 64

Heureaux, Ulises,

Heywood, Li. Col. Ralph, 10

Hispaniola, 1, 3

Honduras, inanning of peace force, $69,71,80$, $83 n .36$

Hotel Embajador, 18, 31, 32-33, 34, 72

Hotel Jaragua, 70, 72

Hotel Matum, 8 ?

Humanitarian aid, $92,51,53,69-70,78,79,84,95$, $96,97 \mathrm{n} .7$

Hungary, 92

tenbert Barrera, General Antonio, 6, 10, 14, 38, $50-51,77,78$

Imbert family, 3

Intorination programs, 49

Inter-American Peace Force, 31, 77

command, 67, 69-70, 73-74

deactivation, 85 .

establishinent, 46, 49, 55, 60, 61, 62, 65-66, 67. 72,93

language problems, 73, 95

manning, $69-71,73-74,93$

mission, 67

supplying, $71,88 n .36,93$

support for provisional government, 79-83

International Security Zone, 46,74

establishment, $23,40,62,63-64,76$

expansion, 53

peace-feeping in, 53

recognition of, 90

Johnson, Lyndon, B., 20

Benoit request for help, 21

briefing by Rusk, is

Communist threat in Dorninican, 7, 23, 24,

$25-26,42,43,61,64,66,67,93,94$

concern with public image, $20,34,92$

decision to cominit combat troogs, 1, 23, 34, 63

decision to Land Marines, $18,21,23$

domestic opposition to policies, 21, 26, 94, 95

formation of Dominican provisional government. 78

"Johnson Doctrine," 63

OAS opposition to policies, 42, 61, 65-66

onder to evacuate civilians, 32,3 \}

Palmer's mission, 94 
policy in Dominican, 22, 24-25, 47, 53-55, 64, 66,92

policy in Latin America, 7, 24, 31, 37, 46

preoccupation with Southeast Asia, 16

use of news media, 21, 25, 26, 34, 60

Joint Chiets of Stalf, 22, 70

buildup of U.S. torces, 44

evacuation of civilians, 17, 32, 33

intelligence, 32

landing of Marines, 21

landing of POWER PACK I, 37

Operation BLUE CHIP, 37

Operation Plan 310/2, 36

policy in Caribbean, 7

supplying peace force, 71

troop withidrawals, 49

and York, 37, 40

Kennedy, John F. See alvo Alliance for Progress. Bay of Pigs, 24

Cuban missile crisis, 24

policy in Caribbean, 7, 9, 23-24

relations with Bosch, 24

Kihrs, Peter, $97 \mathrm{n}, 3$

Latin American Brigade, $\mathbf{3 0}$

Brazilian Battalion, 74, 76-77

Fraternity Sattalion, 73, 76

Liberal Revolutionary Party, 15

Line of coenmunication, 31, 90, 51, 74, 76, 80, 95 effect, 47

establishinent, $46-47$

expansion, 53

peace-keeping in, 53

Limill, Brig. Gen. Robert R., 83, 84

Los Tigres, 19

Loyalists

adoption of name, 15

Connett's opinion of, 17

and Dominican provisional government, 77,78

fighting with Constitutionalists, 50-51, 80

formation of junta, 20

neutralization of, $39,47,53,76,77,96$

refusal to support Reid, 16

retreat to San fsidro, $40,43,46$

U.S. hopes to bolster, 23, 34, 37-38, 46, 94

MeNamara, Robert S., 36, 37, 69, 71, 74

Mann, Thomas, 18

Marinko, llenar Penna, 7 ?

Martin, John B., 4, 42, 50

Masterson, Vice Adm. Kleber \$., 38, 39

Matlos, Col. C. de Miera, 73

Medical aid, $42,53,59 n .55$

Mella, Ramon, 3

Mella Battation, 79

Mella Camp, 18

Mexico

concern about cornmunisin, 65

humanitarian aid, 70

opposition to intervention, 64,65

sponsorship of OAS resolution, 64-65

Military Assistance Advisory Group, 10, 13, 47

Mollina Urena, Jose Rafael, 15, 17, is-20

Moorer, Admiral Thomas A., 32, 70, 71. See also Commander in Chief, Atlantic.

Mora, Jose A., 63, 65, 67, 69, 72

Morse, Wayne, 26, 97 ค. 3
National Civic Union, 15

National Security Council, 26

Naval force, U.S. show of, 7

New York Times, $97 \mathrm{n.3}$

News media, 16, 25, 33, 34, 42, 69, 76, 94, 97n, 3

Nicaragua, $69,72,73,89$

Operation BLUE CHIP, 36-37

Operation Plan $310 / 2,36,43$

Operation Plan STRIKE BREAKER, 51

Organization of American States (OAS), 22, 51, 53, 55, 72, 92, 90. Sec also Mora, Jose A.t Pan American Union.

ad hoc committee, 77,82

Central Election Committee, 83

charter, 63, 64, 67

condernnation of intervention, 25, 42, 60, 61

control of peace force, 71

Council

debates on Dominican, 23, 62-64

Inter-American Peace Cominission, 62

investigating comenit tee, 6

opposition to intervention, 40-42, 46, 62

sanctions against Trujillo, 6

special corninit tee reports to, 65, 66

deactivation of peace force, 84

debates on intervention, $40,46,60,61,63$

expulsion of Cuba, 25, 62

Human Rights Commission, 6, 77

observation team, 83

offer to have Brazil name peace force coinmander, 69

opposition to establishing peace force, 65-66

political objectives shared with U.S., 93

prestige gained by peace fonce, 93

Relief Coordination Center, 70

resolution establishing International Security

Zone, 23, 40, 62

special committee, 65-66

signing of Act of Santo Domingo, 49-50

U.S. influence on, 65

support for evacuation of civilians, 34

Tenth Meeting of Ministers of Foreign Affairs,

$46,50,62,77$

call for humanitarian aid, 69

call for withdrawal of peace force, 34

control of peace force, 67

Dominican issue raised before, 63

opposition to intervention, 64

U.S. diplomatic efforts before, 64

vote on establishing peace force, 65, 66-67

U.S. troop withdrawals, 75

Ozama River, 16, 18, 39, 40, 47, 51, 80

Palmer, Lt. Gen. Bruce, Jr.

appointment as commander of U.S. forces, 43 deputy commander of peace force, 73, 76, 83

desire to link U.S. forces, $49-46$

emphasis on restraint, 49, 95, 96

formation of peace force cadre staff, 70, 73, 95

humanitarian aid, 47

mission from Johnson, 95

peace treeping mission, 51

protection of U.S. influence in peace force,

$70-71,70$

support of U.S. and OAS diplomatic efforts, 47

Pan American Sanitary Bureau, 70

Pan American Union, 96, 61, 63

Panama

humanitarian aid, 69,70 
maming of peace force, s4

reaction to landing of Marines, 62

representation on OAS special committee, 65

Paraguay, manning of peace force, $69,72,85$

Patria, 53

Pentagon, 43

Peru

hemanitarian aid, 70

vote on establishing peace force, 67

Poloney, Carlos Grisolia, 30

Pope Alir Force Base, 23, 44, 49

Postigo, Julio D., 50

POEER PACK 1

arrival in Dominican, 22, 23, 36, 37-39, 49, 90

deployment to Puerto Rico, 37

POWER PACK 1-IV, 44

POEER PACK II, 62

Preas Libre, is

Psychological warfare organizations, 44

Puer to Plata, 53

Puerto Rico, 15, 17, 23, 32, 33, 36, 37, 39, 44, 70

Raborn, william $F_{2}, 22,25$. See also Central Intelligence Agency,

Radio Mavana, 9, 5 )

Radio Santo Domingo, 13, 17, 43, 50, 51, 82, 83

Ramey Air Force Aase, 23, 37, 18, 39, 4h

Rayburn, Sam, 26, 97n.3

Ready Reaction Force, 8 )

Rebels. See Constifutionalists.

Red Cross

Dominican, 27, 70

International, 70

"Rezulations for the OAS inter-American Force," 7

Reid Cabral, Donald

appointment of Wessin y Wessin as chief of armed forces, 15

atteinpted reforins, 9-10,25

capture by Constitutionalists, 15-16

collapse of governinent, 25

expected coups against, 10, 13

head of junta, 9, 13

at outbreak of civit war, 13-14

pro-U,5, policy, 9, 25

U.S, relations with, 25

vice-presideat of council of state, 8

Relief agencies. Sece humunitarian aid.

Rodriguez Echevartia, General Pedro Ratael, 8

Roosevelt, Frarklin D., 23, 24, 25, 31, 63. See also Good Neighbor Policy.

Roosevelt, Theosore, 9

Rostow, Walter, 26

Rusk, Dean, 15, 16, 20, 21, 62, 63, 69, 74 communications with U.S. embasy in Santo

Doeningo, 27

reports to Johnson, 17, 18

warning to Trujillo, 6

San Cristobal, 18

San Isidro Airfield, s, 14, 16, 18, 20, 23, 36-40, 43, $46,46,47,49,50,62,64,71,72,74,82,94$.

See also Armed Forces Training Center.

San isidro Highway, 39

Santiaga, 80, 82

Santo bominzo, early history of, 1, 3-5

School of the Americas, 73

Separation of combatants by U.S. troops, 22, 39. $59,71,99,96$ 16th of August Camp, 13

Soto, Miguel, 13

Southeast Asia, 48

Soviet Union, 24,42

Sumner, Charles, 4

Supreme Court of Justice, 90

Szulc, Tad, $16,97 \mathrm{na}$

Thomas, Norman, 83

Tompkins, Maf. Gent. R. McC., 12

Trade patterms, Latin American, 60

Troog streng th, 44,97

Trujallo, Hector Bienvenido, 7

Trujillo, lose Arismendi, 7

Trujillo, Ram fis, 6-7

Trujlilo Molina, Generalissimo Ratael Leonidas, 36, 61

aftermath of regime, $1,7-3,21$

as anti-Communist, $5,12 n, 22,10$

ascent to power, 5

assassination, $1,6,50$

attemp: to ascassinate Betancourt, 6

corruption of regime, 5,9

as dictator, 1, 5-6, IIn.11

and Dominican Secret Police, 5

election to presidency, 4,5

and national police,

OAS censure, 6

popular support, s

resignation from office, 6

Trujilis residence, 69

27 th of February Camp, 13, 79, 80

United Nations, 6?

Uruguay, 6, 64, 67

U.S. Agency tor International Development, 70

4.5. Air Force

19th Air Force, 46

331 st Fighter hterceptor Squadron, 64

353d Tactical Fighter Squadron, 64

363d Composite Reconnaissance Unit, 40

eleinents in peace force, 74

Joint Air Traftic Coordinating Center, 47

support of U.S. sround troops, 37, 39, 43

Tactical Air Command, 39

U.S. Army

Continental Arnoy Command, 36

XVilt Alrborne Corps

\$2d Airborne Division, 21, 26, 31, 40, 42, 44, $47,72,76,94,96$

Ist Brigade, $76,79-80$

24 Brigade, 43, 79-50

Ist Battalion, 504th Infantry, 80

Ist Battalion, 505 th Infantry, 39

Ist Battalion, 503 th lnfantry, 39, 00, 46

$2 d$ Battalion, 904 th Infantry, 79, 80

2d Battation, sos th Infantry, 80, 8 ?

3d Brizade. See POEER PACK I.

Air Force support, 37

artillery support, 49,74

Ist Battalion, 319th Artillery, 39n.47

ist Buttalion, 320th Artillery, si, $89 n+47$

2d Battalion, 321st Artillery, 89n.47 decision to commit, 23, 39, 63 deployment, 36, 37, 33, 64, 94 ground advance into Santo Domingo, 39

incorporation into peace force, 95

as means to political settleinent, 96 
mlitary sugeriority, 9 ?

OAS reaction to deployment, 62

role of, 92

101 st Airborne Division, 43

headquarters, 36, 37, 49

manning of peace force cadre staft, 70

Operation Plan $310 / 2,36,43$

Strilke Command, 38

Support and logistic units, 69

5 th Logistics Group, 48

7 th Special Group Forces Group, 44, 51, 53, 76

16 th Cieneral Supply Group. 74

ISth Field Hospital, 42

16th General Supply Group, 74

20th Chemical Detachment, $89 n, 47$

307 th Medical Battalion, 4?

U.S. Forces, Dominican Republic, 43, 44. See also

Palmer, L.t. Gen. Bruce, Jr.

as compleinent to negotiations, 53

neutrality, $51,92,95-96$

U.S. Marine Corps.

4th Marine Expeditionary Brigade, 47

6th Marine Expeditionary Brigade, 23

3d Batealion, 40

evacuation of civilians, 31

securing International Security Zone, 63-64

Marine Helicogter Squadron 264, 31

Pathfinders, 39

U.S. Navy

Nary Department, 4

Tavk Force $44.9,17,23$, See also Dare, Capt.

James $\mathrm{A}$.

amphibious landing excercises, 31

deployment, 32

evacuation of civilians, 31-34

U.5, State Departinent, 37, 61, 73, Ses also

Rusk, Dean.

communications with Bennett, 42

Dominican elections, 83

osychological warfare organizations, 49

relations with Reid, 10, 16

role in intervention, 32, 42, 43, 92

U.5.5. Bover, 32, 33, 34, 38, 39
U.5.5, Raleish, 33

U.S.S. R. Fuchamkin, 31, 3 )

U.5,5, wood County, 31, 33

Vasquez, General Horacio, 4, 5

Vaughn, Jack Hood, 18, 32

Venezuela. Sne also Betancourt, Romula.

humanitarian ald, 70

manning of peace force, 69

opposition to intervention, 64

rote on establishing International Security Zone,

6ts

vote on estat thining peace force, 67-69

Vieques Islands, 32

Vietnain, 26

Vilia Consuelo police station, 20

villa Duarte, 40

Wessin y Wessin, Beig. Gen. Elias, 8, 9, 14-17, 33, 63, 50, 78. See also Armed Forces Training Center.

Wheeler, General Earle Ci, 22, 32, 42. See alvo Joint Chiefs of Staft.

appointment of Palmer, 43

landing of POWER PACK L, 37-33, 39

relations with Palmer, 70,71

Wilson, Woodrow, 4

Withdrawal of U.S. troops, 59

beginning of, 74

discussions about, 49

effects of, 74-76

as lever for creation of peace force, 49

OAs call tor, 66

world War II, 23, 24

York, Maj, Gen, Robert H., 36, 46. See also U.S. Army, XVIII Airborne Corps, 82 d Airborne

Division.

appointment as coinmander of U.S. ground forces in Dominican, 17

ground advance into Santo Domingo, 39

landing of POWER PACK 1, 38, 39, 49, 64

requests to Joint Chiefs of Staff, $40-42$ 